
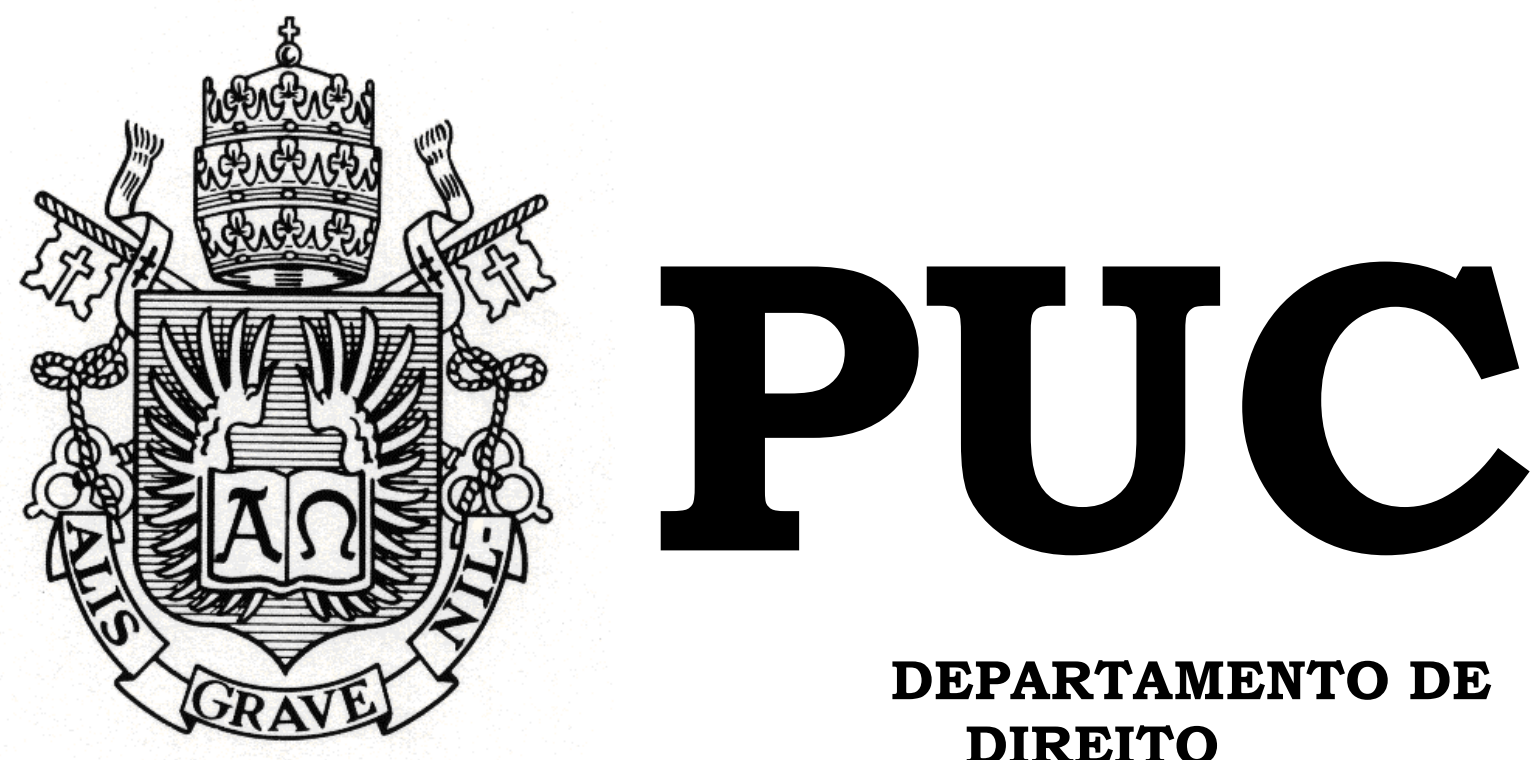
DEPARTAMENTO DE DIREITO

\title{
REDES COBRINDO AS RUAS: AS NARRATIVAS DE MÍDIA SOBRE AS MANIFESTAÇÕES DE JUNHO DE 2013 E O DIREITO À MEMÓRIA
}

por

INGRID BORGES DE LEMOS

ORIENTADOR(A): ADRIANO PILATTI

2015.1

PONTIFÍCIA UNIVERSIDADE CATÓLICA DO RIO DE JANEIRO

RUA MARQUÊS DE SÃO VICENTE, 225 - CEP 22453-900

RIO DE JANEIRO - BRASIL 


\title{
REDES COBRINDO AS RUAS: AS NARRATIVAS DE MÍDIA SOBRE AS MANIFESTAÇÕES DE JUNHO DE 2013 E O DIREITO À MEMÓRIA
}

\author{
por \\ INGRID BORGES DE LEMOS
}

Monografia apresentada

ao Departamento de Direito da Pontificia Universidade Católica do Rio de Janeiro (PUCRio) para a obtenção do Título de Bacharel em Direito.

Orientador(a):

ADRIANO PILATTI 
Ao meu Victor Hugo Borges de Lemos Ponso (In Memoriam).

Eu apenas queria que você soubesse que aquela alegria ainda está comigo. E que a minha ternura não ficou na estrada, não ficou no tempo, presa na poeira. (Gonzaguinha) 


\section{Agradecimentos}

Ao professor Adriano Pilatti, que muito prontamente aceitou minha presunção de realizar uma abordagem fora dos debates tradicionais sobre o evento recortado.

À professora Myrian Sepúlveda dos Santos, que há muitos anos me inseriu nos estudos de memória e cujas lições constituem importante paradigma para aqueles que pretendem trilhar o caminho de pesquisas sobre o tema.

À professora Rachel Nigro, por seu estímulo afável e contribuição intelectual.

Aos membros professores da banca, que se dispuseram a participar da análise deste trabalho, transcendendo essa missão com seus comentários e observações.

À Vice-Reitoria para Assuntos Comunitários (VRC) da PUC-Rio, que com seu programa institucional de bolsas de estudo, possibilitou minha graduação em Direito numa universidade de excelência.

À minha mãe Fátima e meus irmãos Bianca e Gustavo, que contribuíram para minha formação moral e intelectual, cujo imprescindível suporte afetivo e material guardo carinhosamente no coração e na lembrança.

Ao Victor Hugo (in memoriam), a razão e o porquê. 


\section{RESUMO}

O presente trabalho elegeu como objetivo a análise da possibilidade de articulação entre as narrativas midiáticas (novas e velhas mídias) das manifestações de junho de 2013 e o direito à memória. Para tanto, percorreu o seguinte caminho: (i) conceituou a memória coletiva à luz das principais teorias sobre o tema; (ii) abordou o entendimento doutrinário e aplicações do direito à memória no Brasil; (iii) narrou a evolução das manifestações de junho de 2013 e sua abordagem pelas redes midiáticas; (iv) procurou fazer uma síntese crítica sobre as possibilidades de efetivação do direito à memória aplicado às narrativas não hegemônicas produzidas por mídias alternativas quando comparadas às das mídias tradicionais.

Palavras-chave: direito, memória coletiva, mídia, informação, manifestação, junho de 2013. 


\section{SUMÁRIO}

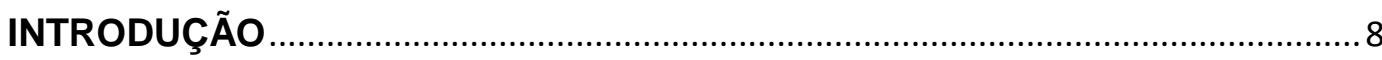

1. CONSIDERAÇÕES SOBRE O TEMA DA MEMÓRIA ............ Erro! Indicador não definido.3

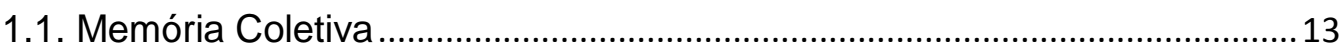

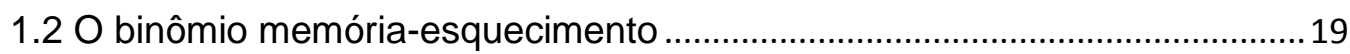

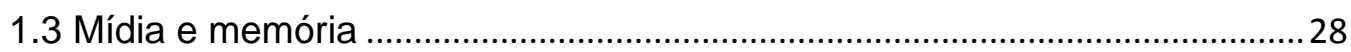

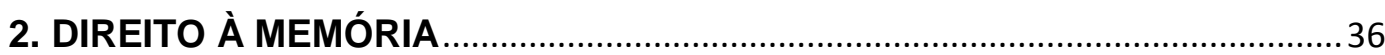

2.1. Memória como Patrimônio Cultural …………................................................38

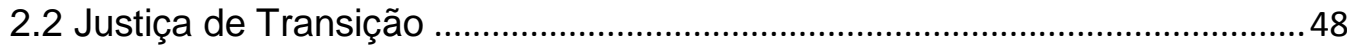

2.3 Preservação dos conteúdos de mídia ...............................................................54

3. NARRATIVAS MIDIÁTICAS PRODUZINDO MEMÓRIA SOBRE AS MANIFESTAÇÕES: TERRITÓRIOS EM DISPUTA ................................................64

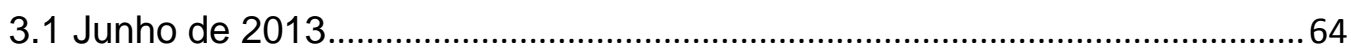

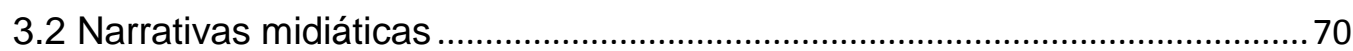

3.2.1 As manifestações nas redes sociais............................................................... 73

3.2.2 As manifestações nas velhas redes ..................................................................78

4. NARRATIVAS DAS MANIFESTAÇÕES E DIREITO À MEMÓRIA....................88

5. CONCLUSÃO

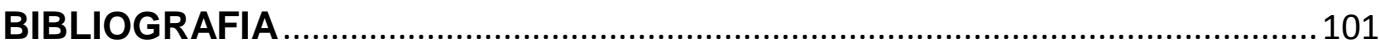




\section{LISTA DE SIGLAS}

$\begin{array}{ll}\text { ADPF } & \text { Ação de Descumprimento de Preceito Fundamental } \\ \text { BN } & \text { Fundação Biblioteca Nacional } \\ \text { CF/88 } & \text { Constituição Federal de } 1988 \\ \text { CNV } & \text { Comissão Nacional da Verdade } \\ \text { IPHAN } & \text { Instituto do Patrimônio Histórico e Artístico Nacional } \\ \text { MPL } & \text { Movimento Passe Livre } \\ \text { NINJA } & \text { Narrativas Independentes Jornalismo e Ação } \\ \text { STF } & \text { Supremo Tribunal Federal } \\ \text { STJ } & \text { Superior Tribunal de Justiça } \\ \text { UNESCO } & \text { United Nations Educational, Scientific and Cultural }\end{array}$




\section{LISTA DE ILUSTRAÇÕES}

Gráfico1. Percentual de assuntos nas redes sociais(jun/13)

Gráfico 2. Percentual de matérias com classificação valorativa sobre as ações dos atores (jun/13) 85

Gráfico 3. Proporção de matérias com fala direta ou indireta de manifestantes 86

Gráfico 4. Percentual de matérias que respeitam o princípio do contraditório 86 


\section{INTRODUÇÃO}

Em junho de 2013 o mundo assistiu a uma onda de manifestações em diversas cidades do Brasil em protesto contra o aumento no valor da passagem dos ônibus. A estimativa é que no período mais de um milhão de pessoas tenham ido às ruas protestar. Antes disso, as primeiras mobilizações já haviam ocorrido em Porto Alegre, no mês de março do mesmo ano, mas foi a partir dos protestos organizados pelo MPL (Movimento Passe Livre) no dia 06 de junho em São Paulo que a irradiação se deu para as principais capitais e depois para centenas de cidades. Tal poder mobilizador só esteve antes presente na Passeata dos Cem Mil, contra

o Golpe Militar de 64, no Movimento Diretas Já, em 1984 e no impeachment do ex-presidente Fernando Collor, em 1992. Desde então não se assistia uma expressão tão vigorosa da vontade popular no país. A diferença crucial entre as manifestações de junho e as anteriores, foi o papel das redes sociais digitais, como Facebook, Twitter, Youtube. Antes os sindicatos e os partidos políticos desempenhavam papel fundamental na organização e conclamação às ruas. Desta vez, a mobilização se deu de forma descentralizada, através das redes virtuais de sociabilidade. Isso também se refletiu nas ruas. A descentralização também se deu em relação às pautas dos protestos, que se iniciaram contra o aumento das tarifas de ônibus e depois foram revelando um profundo inconformismo com o status quo político-representativo, incluindo a insatisfação com os partidos políticos. Grupos suprapartidários como o Anonymous, MPL e outros, além de cidadãos não vinculados a grupo algum, questionavam conteúdos difusos dando vazão ao descontentamento que fora se desenhando no momento anterior com os gastos públicos elevados nos preparativos dos megaeventos como as Olimpíadas de 2016, a Copa das Confederações de 2013 e a Copa do Mundo de 2014. Foram inúmeras denúncias de construção de estádios superfaturados, falta de transparência nas contas das obras, aplicação do 
dinheiro público em prol do capital privado concentrado numa pequena elite em desfavor da imensa maioria da população que sofria com a precariedade da saúde, educação e transportes públicos, além da falta de moradia em razão da onda dos despejos e remoções realizados no mesmo período para atender a fome do mercado imobiliário.

Outro sinal de desgaste de representação foi a clara disjunção entre o sentimento compartilhado pela explosão emocional popular e o sentido dado pela cobertura realizada pela imprensa tradicional. Logo na primeira semana dos protestos em São Paulo a grande mídia procurou desqualificálos tratando os eventos como atos de vandalismo. Os meios formais de comunicação criaram edições de reportagens que notoriamente procuravam criminalizar os movimentos e despertar o temor do público.

A grande virada que determinou o apoio da sociedade aos manifestantes, até então qualificados pela grande mídia como "vândalos" e terroristas, foi o emprego desmedido de violência estatal através da polícia. Cidadãos foram recebidos com bombas de gás lacrimogênio e tiros de borracha. Começaram a circular no mundo inteiro imagens de manifestantes feridos pela polícia, gravadas por anônimos através de celular. A tônica da imprensa oficial muda em apoio aos protestos. Em 20 de junho a adesão popular foi maciça, reunindo mais de um milhão de pessoas em 75 cidades do Brasil. Novamente surgiu a violência policial, mas de forma ainda mais intensa e com ela, muitos episódios de depredações ao patrimônio público e privado. A repressão da polícia teve como efeito, além da intimidação da população, o reforço da tônica jornalística que criminalizou os eventos e passou então a dividir os que protestavam em duas categorias: os "manifestantes pacíficos", que mantiveram sua cidadania legitimada, e os "vândalos", que adotaram a prática black bloc.

Em contraponto, a democratização informacional promovida pelas redes de tecnologia digital, com o emprego de celulares e internet, permitiu a transmissão não editada dos fatos, muitas vezes ao vivo, sob vários ângulos e perspectivas que desmentiam a versão da mídia tradicional. 
Surgia o ativismo digital da mídia livre confrontando a velha forma manipuladora do jornalismo convencional, que reiteradamente era obrigado a retificar seu conteúdo mediante as pressões das novas evidências factuais veiculadas nas mídias sociais. A redescoberta das ruas foi marcada pela disputa das narrativas de redes. De um lado havia as redes digitas formadas a partir do espaço físico das ruas se relacionando com as redes sociais virtuais. De outro, as redes de comunicação tradicionais que tanto temporalmente quanto simbolicamente perdiam "espaço" junto à opinião pública. As disputas pela cidade, antes evidenciadas no espaço físico pelas dinâmicas dos "interesses do capital privado x direito de moradia" e dos "manifestantes x policiais", se transpunha para o campo das narrativas comunicacionais.

O controle pelo sentido narrativo das manifestações de junho de 2013 se insere naquilo que pode ser compreendido como disputa pela construção da memória política do país. Os meios de comunicação funcionam como lugares de memória em sentido simbólico, material e funcional, pois a seleção e edição do conteúdo veiculado, frequentemente associado a juízos de valor escamoteados pelo verniz da "verdade factual", promovem memória e esquecimento. Estes meios constituem potencialmente um sistema de poder simbólico que pretende se reproduzir ideologicamente no conjunto de práticas sociais. Os vencedores escrevem a história porque vencem, mas também vencem porque escrevem a história. Esse processo dinâmico da produção de memória é vetorizado por forças sociais em conflito. Decorre disso que a disputa pelo sentido dos eventos é em última análise uma disputa de forças pelo poder de influência no destino político como condição de satisfação dos próprios interesses. Num contexto de multipolaridade de atores e democratização de acesso à informação em razão das novas tecnologias informacionais globalizadas, não cabe um sentido político concebido de forma monolítica, aquela com a qual a velha estrutura de imprensa está vocacionada a trabalhar. A multiplicidade de cidadanias culturais em luta emancipatória no cenário político não pode ser 
institucionalizada num sentido unívoco e ameaça a lógica da mídia tradicional ao denunciar seus métodos manipuladores e descompromissados com a verdade através da mídia livre, dos repórteres de ocasião que têm a seu favor a integração entre câmara de vídeo e internet do celular.

A preocupação com o potencial enganador da memória devido a seu caráter de seleção, reconstrução e interpretação narrativa está presente desde quando o termo se originou no mundo ocidental, na Grécia Antiga. No Brasil, a atenção com a memória e a verdade se concentrou recentemente nas investigações de direitos humanos sobre a questão da justiça de transição. A Comissão da Memória e Verdade (CNV) foi criada em 2011 para promover o esclarecimento público sobre as violações de direitos humanos como torturas, mortes e desaparecimentos forçados perpetrados por agentes de Estado no período da ditadura militar (19641984), a fim de efetivar o direito à memória e à verdade histórica, possibilitando a reconciliação nacional com seu passado. Em dezembro de 2014 a CNV divulgou seu relatório, começando a reescrever a História. Aqueles que haviam sido criminalizados como "terroristas" e "subversivos" ganharam a oportunidade de ter sua memória e identidade resgatadas. Em agosto de 2013, ainda sob o auge da indignação popular, um editorial jornalístico chegou a reconhecer o erro histórico de sua empresa de comunicação ao apoiar o golpe de 64 .

A imprensa que havia chamado a ditadura de "revolução", os perseguidos políticos de "terroristas" e que se desculparia 50 anos depois, era a mesma que classificava como "vândalos" aqueles que foram às ruas em 2013, num clara tentativa de criminalizar a resistência popular à nova arquitetura de exclusão social.

$\mathrm{O}$ direito à memória, apesar de não positivado na Constituição Federal de 1988, encontra-se albergado na legislação pátria de maneira tácita e difusa, à exceção da lei que cria a CNV, cujo texto expressamente menciona a finalidade de efetivar o direito à memória e à verdade histórica sobre as graves violações ocorridas no período de 1946 a 1988. O ramo do 
direito ambiental compreende o direito à memória, uma vez que o meio ambiente não se limita a aspectos naturais da vida, mas abarca o trabalho e a cultura, abrangendo o homem na sua relação com a natureza em sentido lato. Por isso o direito à memória deve ser entendido na combinação entre os dispositivos constitucionais que tutelam o direito ao meio ambiente e os direitos culturais. Além disso, há uma teoria que defende o direito à memória como direito fundamental implícito, pois sem ele a sociedade perderia seu elemento de coesão. $\mathrm{O}$ mesmo ocorre com o direito à verdade, que se articula com o direito à informação, um direito-dever previsto em nossa Constituição que efetiva a democracia. A questão do direito à memória e à verdade é amplamente estudada pelos direitos humanos.

Mediante esta exposição, o presente trabalho tem como objetivo a discussão da produção de memória sobre as manifestações iniciadas em junho de 2013 no Brasil, através das narrativas midiáticas à luz do direito à memória. O desenvolvimento desta proposta se baseou na articulação entre o material bibliográfico sobre o tema, o material produzido por diversas mídias (vídeos, áudios), entrevistas com questionário semi-estruturado e observação participante. 


\title{
1. CONSIDERAÇÕES SOBRE O TEMA DA MEMÓRIA
}

\begin{abstract}
O tempo do romance de Kafka é o tempo de uma humanidade que perdeu a continuidade com a humanidade, de uma humanidade que não sabe mais nada, que não se lembra de mais nada e que mora em cidades que não têm nome e cujas ruas são ruas sem nome ou com um nome diferente do de ontem, pois o nome é uma continuidade com o passado e as pessoas que não tem passado, são pessoas sem nome.
\end{abstract}

(Milan Kundera $^{1}$ )

O presente capítulo pretende explorar o conceito de memória que irá orientar a compreensão deste trabalho, tendo como principal referência os estudos de Halbwachs, o influente teórico que pioneiramente concebeu a memória como objeto de estudo social, limitado no tempo e no espaço por contextos culturais, sociais e políticos. Também serão analisadas de forma dialógica as contribuições de outros importantes estudiosos que abordaram o tema da memória.

\subsection{Memória Coletiva}

Ao longo do tempo o conceito de memória sofreu várias transformações e atualmente o termo pode ser compreendido em diversas acepções.Na tradição oral da Grécia antiga, a memória era representada pela deusa Mnemosyne, cujo nome deriva do verbo mimnéskin ("lembrarse de"). A divinização da memória no panteão grego nos informa o valor da rememoração para essa antiga civilização. A compreensão dos mitos, segundo Junito Brandão (1986) poderia se dar a partir da chave de ligação entre os arquétipos junguianos de inconsciente coletivo (ideias primitivas herdadas de gerações passadas, cuja origem não se pode determinar) com o consciente coletivo (termo cunhado por Jung). Os mitos funcionariam como guardiões dos símbolos que dão acesso à consciência coletiva de uma cultura específica, mas também forneceriam elementos de orientação para

\footnotetext{
${ }^{1}$ KUNDERA, Milan. O Livro do Riso e do Esquecimento. Rio de Janeiro: Nova Fronteira, 1987. p.
} $177-178$ 
leitura dos símbolos que estão na raiz de qualquer consciência coletiva definidora de identidades culturais.

“Os conteúdos do inconsciente pessoal são aquisições da existência individual, ao passo que os conteúdos do inconsciente coletivo são arquétipos que existem sempre e a priori” (JUNG apud BRANDÃO, 1986). ${ }^{2}$

Pertencente à geração divina das Titânidas, Mnemosýne deu à luz as nove Musas, filhas de Zeus, que possuíam o dom de imortalizar, através de seus cantos, a vitória do pai contra os Titãs, mas, principalmente, governavam o "pensamento sob todas as suas formas: sabedoria, eloqüência, persuasão, história, matemática, astronomia”. (BRANDÃO, 1986, p.203). Mnemosýne preside a função poética, de caráter onisciente e divinatório, detendo a sabedoria de "tudo o que foi, tudo o que é, tudo o que será" (HESÍODO 3 apud VERNANT, 1990, p.138). Sob a intervenção das Musas, que cantam genealogias, a arkhé do universo, dos deuses, do homem, enfim, da origem do tempo mítico, o poeta estabelece uma ponte com o conhecimento de Mnemosýne. Em seus cantos podiam aparecer os "Catálogos" de nomes importantes nas efemérides originais. "Constituem os arquivos de uma sociedade sem escrita, arquivos lendários" (VERNANT, 1990. p.140). Em Teogonia, de Hesíodo, Mnemosýne recebe das filhas o bastão da sabedoria, capaz de fazer emergir a Verdade através do passado rememorado, que, longe de aludir a uma cronologia temporal, promove o conhecimento de uma espécie de imanência ontológica a partir da qual o vir-a-ser se revela (devir). A visita ao passado libera o poeta que rememora, das angústias do presente. Assim, Mnemosýne também é capaz de fazer esquecer e por isso pode aparecer associada a Léthe, Esquecimento. Além disso, os elementos que o poeta recupera no passado indicam sua ausência no presente. Vernant observa que nos rituais de

\footnotetext{
2 JUNG, CG. Aion - Estudos sobre o Simbolismo do Si-mesmo. Tradução de Dom Mateus Ramalho Rocha, O.S.B. Petrópolis, Vozes, 1982, p. 6

${ }^{3}$ Ilíada, I, 70; Hesíodo, Teogonia, 32 e28.
} 
descida ao Hades (boca do inferno) o consulente deveria beber da fonte de Léthe para esquecer sua vida terrena e ingressar no mundo das sombras. Quando associada às Musas, Mnemosýne permitia ao poeta o conhecimento do passado e do futuro, mas a Titã também representava a travessia para o domínio da morte quando a referência era Léthe.

Esquecimento é pois uma água de morte. Ninguém pode abordar o reino das sombras sem ter bebido nessa fonte, isto é, sem ter perdido a lembrança e a consciência. Ao contrário, Memória aparece como uma fonte de imortalidade (...). (VERNANT, 1990, p.144)

Na Grécia Antiga o compartilhamento dos feitos dos heróis mortos através dos cantos transmitidos continuamente por gerações, permitiu a coletivização de uma memória que funcionou como amálgama entre os helenos, fortalecendo os laços de solidariedade, fornecendo o sentido de pertencimento comunal, e assim, a percepção da própria identidade.

$\mathrm{Na}$ primeira metade do século $\mathrm{XX}$, tendo como principal influência não a tradição helênica, mas a escola de pensamento sociológico de Durkheim (segundo a qual os fatos sociais devem ser tratados como coisas), de quem foi aluno, o sociólogo Halbwachs foi o precursor dos estudos que abordaram a memória como um fenômeno social definido rigorosamente sob o aspecto coletivo (fato social), quando até então, fora as abordagens míticas das sociedades arcaicas, todas as interpretações acerca desse objeto apontavam apenas para aspectos psicológicos e subjetivos. O termo "memória coletiva", que intitula uma de suas principais obras (publicada postumamente em 1950), só pode ser compreendido pela complementaridade existente entre indivíduo e sociedade (dimensões até então apresentadas como a grande antinomia das Ciências Sociais) a partir de molduras preestabelecidas, que o teórico chamou de "quadros sociais da memória" (Les cadres sociaux de la mémoire, publicado em 1925, foi o trabalho que deu projeção a Halbwachs) dentro dos quais se processam representações coletivas. Os indivíduos apenas podem recordar a partir de estruturas que os antecedem (SANTOS, 2003). Rechaçando a concepção subjetiva, Halbwachs (1990) observa que aquilo que poderíamos objetar 
como memória individual, nada mais seria do que lembranças que se desenvolvem dentro de quadros sociais definidos no tempo e no espaço, evocadas por homens determinados socialmente. Dentro destes quadros, indivíduos transitam em variados grupos, isto é, fazem parte de uma grande diversidade de pensamentos sociais que se transformam com o tempo. Se de um lado as representações coletivas se impõem aprioristicamente a cada consciência individual, esta, por sua vez, dá continuidade a estas representações, assim entendidas como a própria consciência coletiva (tradições, organizações, linguagens, símbolos). A memória autobiográfica (evocada no quadro da personalidade individual) estaria apoiada na memória social ou histórica (memória externa, de caráter impessoal), uma vez que ocorre dentro dela. Circunstâncias políticas e nacionais das quais fazemos parte, nos tornam homens do nosso tempo e na medida em que nos reconhecemos como partes integrantes disso, conseguimos dar sentido a nossas lembranças pessoais mais remotas. Halbwachs narra a própria experiência de rememoração de sua infância. Aspectos no comportamento de seus pais ganham sentido não mais como traços distintivos da natureza pessoal destes, mas porque estes eram fruto de um tempo e espaço delimitados. Por isso, para o sociólogo, não convém separar memória individual de memória coletiva, pois aquela é arrastada pelas correntes de pensamento social desta.

A partir dessa perspectiva, Halbwachs procura mostrar que a lembrança reconstrói o passado atualizando-o em conformidade com a consciência e as representações constituídas no presente, o que confere um caráter racional e potencialmente mutável a essa reconstrução. Longe de ser um recorte cristalizado de um passado objetivo, a memória é variegada de elementos do presente e por isso pode tanto vicejar nas consciências individuais, como ultrapassá-las através das comunicações transindividuais, permitindo o fortalecimento dos laços de solidariedade grupal pela sensação de pertencimento a um universo comum de trocas simbólicas. Essa circulação só é possível porque memória e linguagem são inseparáveis. Os 
indivíduos se comunicam porque comungam dos códigos que dão acesso ao sentido das paisagens, dos eventos históricos, de tudo que há no cotidiano. Mas a estabilidade da comunicação, isto é, da própria memória coletiva, depende da influência mutuamente sobredeterminada entre lugar (imagem do espaço) e grupo (consciência coletiva).

A memória coletiva é o passado que sobrevive no presente, mas que só pode se sustentar enquanto "história vivida" na consciência social. Assim, adverte Halbwachs, aquilo que chamamos de história, uma sucessão artificial de eventos balizados por esquemas cronológicos, só pode ter sua transmissão garantida formalmente através dos livros e escolas. Quando já não existem mais muitas testemunhas que possam rememorar os acontecimentos, a escrita da história impõe-se como exigência. Isto "porque geralmente a história começa somente do ponto onde acaba a tradição, momento em que se apaga ou se decompõe a memória social". (HALBWACHS, 1990. p.80) Aqui, memória e história são termos excludentes. Enquanto a memória está relacionada à potência vital, a história, ao se pretender ciência pura, traz em seu bojo a ideia de morte e esquecimento. A oposição história versus vida já havia sido elaborada por Nietzsche (1999), para quem a universalização artificial que simula conexões de causa e efeito em favor de uma história fria e teleológica, é anuladora da vida, pois castra o homem em seu potencial criador, uma vez que este se encontra jungido a um sentido histórico imposto do exterior. A memória, ao contrário, nos diz Halbwachs, não tem caráter universal. Só pode existir sustentada por grupos de pessoas limitadas no tempo e no espaço, razão pela qual a flexão "memórias coletivas" seria mais pertinente do que o termo "memória", que poderia nos remeter a um sentido totalizante, o que é inteiramente falso.

Outros estudiosos do tema marcaram sua crítica nesse mesmo sentido. Nora (1993) compreende a história como a organização científica do passado, que não apenas não encontra ressonância nos indivíduos vivos, como, ao pretender planificar sua consciência em direção a um sentido 
linear, destrói os vínculos criados entre eles pelos ritos de solidariedade. Pomian (2000) procura demonstrar que a "reevocação" do passado pertence ao âmbito da linguagem, que busca a interpretação que melhor se adequa ao seu contexto. A multiplicidade de perspectivas históricas prova que a reevocação "é sempre imperfeita, porque o passado não pode, em circunstância alguma ser simplesmente restituído na íntegra, e toda a reconstrução é sempre marcada pela dúvida" (POMIAN, 2000, p.508).

Se por um lado a abordagem de Halbwachs pode ser criticada por ser essencialmente positivista, no sentido sociológico, ao ceder muito pouco à consciência individual, uma vez que sua substância é a memória coletiva (como vimos, esta é composta por correntes de pensamento que "arrastam" as memórias individuais) ${ }^{4}$, de outro lado, pondera Candau (2014), o teórico estava certo em dar relevo aos quadros sociais que iluminam toda rememoração. Estes quadros funcionam como facilitadores da dinâmica evocação- esquecimento, atualizada pela sociedade a qual se aplica.

Nisso toda a memória é social, mas não necessariamente coletiva - e em alguns casos e apenas sob certas condições se produzem 'interferências coletivas' que permitem a abertura recíproca, a inter-relação, a interpenetração e a concordância mais ou menos profunda de memórias individuais. (CANDAU, 2014, p.49)

Assim, de acordo com Candau, quanto maior for a convergência e confluência das memórias individuais sobre a representação do passado (configurando a memória coletiva), maior será a percepção da representação identitária. Por isso, a maior ou menor estabilidade da memória coletiva (e, por conseguinte, da identidade nela plasmada) depende da qualidade e intensidade de interpenetração das memórias individuais.

\footnotetext{
${ }^{4}$ Apesar de ter sido o primeiro a conciliar a dimensão individual com a coletiva, Halbwachs priorizou o papel das estruturas sociais, não os processos interativos entre consciências de cada uma destas dimensões, embora tenha aberto caminho para outros teóricos nesse sentido. Na década de 80 se multiplicam os estudos que procuram resolver essas antinomias por uma abordagem compreensiva, segundo a qual, as memórias deveriam ser compreendidas a partir de estruturas coletivas, processos interativos, práticas reflexivas e construções sociais de forma não excludente. (SANTOS, 2003; 2013).
} 


\subsection{0 binômio memória-esquecimento}

Conforme foi possível compreender até agora, a memória está relacionada a interpretação de práticas e discursos de tempos e espaços específicos, por conseguinte, está diretamente relacionada àqueles que dominam os mecanismos de produção de sentido. Assim, afirma Le Goff (1994), na dinâmica lembrança-esquecimento, estão inscritas disputas das forças sociais pelo poder de fazer lembrar ou fazer esquecer.

Tornarem-se senhores da memória e do esquecimento é uma das grandes preocupações das classes, dos grupos, dos indivíduos que dominam as sociedades históricas. O esquecimento e os silêncios da história são reveladores de mecanismos de manipulação da memória coletiva (LE GOFF, 1994. p.426).

Para alcançarmos os mecanismos de seleção, expansão e retraimento da memória coletiva, é preciso localizá-la, segundo LeroiGourham, em cinco diferentes momentos civilizatórios: "o da transmissão oral, o da transmissão escrita com tábuas ou índices, o das fichas simples o da mecanografia e do seriação eletrônica" (LEROI-GOURHAM apud LE GOFF 1994. p.427). A exemplo do que vimos na sociedade grega arcaica, o autor Jacques Le Goff (1994) assinala que prevalece nas sociedades sem escrita, a memória coletiva ordenada em torno dos mitos de origem, da genealogia de famílias influentes e da transmissão do saber técnico de fundo mágico-religioso. Já a escrita, de acordo com o mesmo autor, favoreceu o desenvolvimento de duas formas de memória: o monumento, que é a celebração de um feito memorável eternizado por inscrições (memória inscricional), e o documento, uma memória que se funda basicamente como prova escrita. Enquanto os monumentos são herança de um passado, concretizando a perpetuação de uma "memória real" (obras arquitetônicas, monumentos funerários), os documentos seguem o critério de uma escolha objetiva e utilitária. Le Goff (1994), remetendo-se à Grécia arcaica, narra como deve ter sido a passagem da memória oral à memória 
escrita: os mnemones, funcionários da memória, eram magistrados que tinham o papel de guardar uma decisão jurídica e tudo o que tivesse relevância em matéria de justiça ou de calendário religioso. Após o aparecimento da escrita, estes homens tornaram-se arquivistas. Nesse sentido, o fundamento do documento estaria em ser memória que serve de prova. Ao longo do tempo, a escrita substituiu e superou em legitimidade a tradição oral. Até os dias de hoje, o documento (notadamente textual) é instrumento não só do poder jurídico, mas de poderes institucionalizados: das ciências, da imprensa, da história e tantos outros. O documento é a materialização simbólica do poder que surge como resultado das interações das forças sociais. "Se a memória é socialmente construída, é óbvio que toda documentação também o é”. Ao fazer essa afirmação, Pollak (1992, p.207) diz não fazer distinção entre fonte escrita e fonte oral. Contrapondose a uma construção positivista do passado apenas pela intermediação documental, exorta os historiadores a fazerem sua crítica metodológica para quaisquer tipos de fontes.

$\mathrm{Na}$ articulação que Pollak (1989) faz entre memória e poder, destaca o potencial destruidor da planificação da memória coletiva (nacional), contrastando com a abordagem durkheimiana de Halbwachs, para quem a memória coletiva não era resultado de uma dominação simbólica, mas tão somente um reforço de vínculo de pertencimento por um sociabilidade afetiva. Entretanto, Halbwachs reconheceu que a fixação da memória coletiva dependia de um processo de conciliação com as memórias individuais. Para que as memórias individuais se apoiassem umas nas outras formando uma memória coletiva, seria preciso que concordassem entre si. É nesse ponto que Pollak situa sua crítica numa perspectiva mais construtivista da memória. Se é preciso haver negociação para construção da memória coletiva, o que irá interessar agora não é a memória como coisa (fato social), mas quais mecanismos a transformam em coisa, quais processos e quais agentes operam na estabilização dessa memória, garantindo sua durabilidade. A partir de então, Pollak privilegia o exame 
dos discursos dos marginalizados através da história oral, isto é, analisa a memória dos excluídos do discurso oficial. Esta memória minoritária sobrevive informalmente concorrendo com uma memória dominante que não é propriamente de um Estado no exercício de uma violência simbólica, mas também de grupos de poder. De acordo com Pollak, os grupos de "memórias subterrâneas" (1989, p.4), operam sua resistência em silêncio, aguardando o momento oportuno de fazer emergir sua consciência comum, o que geralmente ocorre em situações de crise. É nesse momento que surge a concorrência entre memórias. Longe de significar esquecimento, o silêncio aqui significa resistência.

Pollak se refere ao trabalho de justificação de discursos dominantes como "enquadramento de memória" (1989, p.9) processo pelo qual os aparelhos de Estado (comunicação, Justiça, educação), os veículos midiáticos, além de material historiográfico (monumentos, documentos, arquivos) legitimam seus discursos, interpretando o passado em função de objetivos claros, como a manutenção dos vínculos, da identidade do grupo ou de uma ordem política, econômica e social que lhes seja conveniente. Entretanto se as memórias coletivas sofrem processo de enquadramento vertical (de cima para baixo), a memória individual se difunde horizontalmente através da história oral, administrando o sofrimento e discrepância em relação à história oficial. $\mathrm{O}$ autor ainda destaca que o aspecto conflitivo da memória em razão de preocupações pessoais e políticas se revelam mesmo na seleção de datas festivas e feriados nacionais. No Brasil, são exemplos os feriados de Tiradentes e de Zumbi. ${ }^{5}$

\footnotetext{
5 Tiradentes foi morto em 21 de abril de 1792, por ter liderado a Inconfidência Mineira, movimento que se rebelou contra o poder da Coroa Portuguesa. Após a proclamação da República, Tiradentes se tornou herói nacional e o dia 21 de abril passou a ser feriado criado pela Lei 1266 de 1950. O espetáculo de enforcamento criado pela Coroa para intimidar possíveis rebeldes da Colônia, reforçou a memória do evento, criando um efeito contrário depois da mudança no exercício do poder político com a nova República. Tiradentes passou a ser retratado com uma imagem próxima à figura de Jesus Cristo e tornou-se um mártir da história nacional na luta contra o poder de opressão (FAUSTO, Boris. História do Brasil. 6 ${ }^{a}$ ed.São Paulo.Edusp:FDE. 1998 p.660). Já o dia da Consciência Negra é comemorado em 20 de novembro, desde 1978, depois que ativistas do Grupo Palmares descobriram que Zumbi, escravo líder do Quilombo dos Palmares, símbolo da resistência negra, morreu assassinado neste mesmo dia no ano de 1695. Depois de vários anos de luta pelo reconhecimento de Zumbi como herói nacional da luta do povo negro, foi
} 
Assim, enquanto fenômeno construído individual e socialmente, há uma intrínseca correlação entre memória, poder e identidade. O processo de formação identitária, como toda construção social, é marcado pela negociação, uma vez que também implica em uma projeção para o exterior, produzindo-se em referência à alteridade, dentro de uma dinâmica que envolve rejeição, aceitação, estabilidade e transformação. Nesse sentido, “memória e identidade são valores disputados em conflitos sociais e intergrupais, e particularmente em conflitos que opõem grupos políticos diversos" (Pollak, 1992, p. 205). ${ }^{6}$ Aqui, a luta pela memória é a luta pelo direito à afirmação da identidade em sua existência presente e permanência futura.

Por essa percepção, promover o esquecimento significa matar a identidade, realizar um corte ideológico. É o mortal desaparecimento do lago de Lethes. O filme BladeRunner, dirigido por Ridley Scott em 1992, correlaciona ausência de passado com escravidão. No enredo, andróides semelhantes aos seres humanos, inclusive na capacidade de se revoltar contra a injustiça e tirania, encontram como principal entrave à oposição a seus criadores-opressores o fato de não serem dotados de memória de longa duração, mas apenas de uma memória operacional (SANTOS, 2003; ROSSI, 2010). Seus criadores sabiam que a recusa de memória e, por conseguinte, de passado, é condição de dominação contínua, livre das ameaças de uma revolução.“Apagar”, segundo Paolo Rossi, significa tanto transitoriedade (uma vez que não há um sentido cristalizado no tempo que

proposto em 9 de janeiro de 2003 o projeto de Lei $n^{\circ} 10.639$, em favor da criação do dia da Consciência Negra, o que só se efetivou em 2011 com a sanção da Lei 12.519/2011, que entretanto, não determinou a obrigatoriedade do feriado, embora mais de mil municípios tenham adotado a data em seu calendário de feriados oficiais. Fontes: <http://www.palmares.gov.br/wpcontent/uploads/2013/11/Estados-e-Munic\%C3\%ADpios-que-Decretaram-Feriado-no-Dia-20-de-

Novembro-dia-da-Consci\%C3\%AAncia-Negra1.pdf $>$

<http://www.planalto.gov.br/seppir/20_novembro/apres.htm $>$

6 Entretanto, há estudiosos, principalmente os que se debruçam sobre pesquisas de movimentos minoritários, como os ligados a raça, gênero, infância, que entendem que algumas formas de exclusão construídas simbolicamente não passam por negociação, pois não encontram à sua disposição canais de expressão. Assim, discursos igualitários que padronizam algumas pautas em comum de minorias, só servem para reforçar a lógica excludente e segregacionista. (SANTOS, 2003). 
atravessa as gerações sem negociação), quanto ocultação, desvio da verdade, coação da circulação de idéias e culturas, isto é, domínio pela manipulação e desaparecimento. Por isso a história está repleta de episódios onde os conquistadores de territórios imprimiram a destruição de marcas distintivas da cultura local ${ }^{7}$.

O século XX, como menciona Rossi, está repleto de "apagamentos", de histórias de desaparecimento, condenações, eventos seguidos de pedidos de desculpas, retratações públicas, declarações de sentimento de vergonha. A história foi reescrita, livros reeditados com omissões de trechos, nomes foram excluídos, arquivos desapareceram. O holocausto e as ditaduras da América Latina são grandes exemplos.

Primeiro, foram queimados os livros. Depois, foram eliminados das bibliotecas, na tentativa de apagá-los da história. Primeiro, foram eliminados inúmeros de seres humanos, depois, tentaram apagar os apagamentos, negar os fatos, obstaculizar a reconstrução dos eventos, vetar a contagem das vítimas, impedir a lembrança. Os prisioneiros dos campos de concentração escreveu Simon Wiesenthal - eram assim admoestados por seus algozes: "Como quer que termine esta guerra, a guerra contra vocês vencemos nós; nenhum de vocês viverá para dar testemunho, mesmo que alguém escapasse, o mundo não acreditaria em vocês" ${ }^{8}$ (ROSSI, 2010, p.33).

O Filme "Fahrenheit 451", dirigido por François Truffaut em $1966^{9}$, conta a história de uma sociedade onde os livros eram considerados ilegais e onde quer que fossem encontrados, eram queimados por funcionários do Estado, chamados "bombeiros". Para salvaguardar o conteúdo dos livros, foi criada uma comunidade de refugiados, onde cada integrante tinha a função de "ser" um livro vivo, decorando seu conteúdo palavra por palavra, a fim de garantir sua transmissão às gerações futuras.

\footnotetext{
${ }^{7}$ Em fevereiro deste ano (2015), integrantes do Estado Islâmico destruíram estátuas milenares das civilizações acádias e assírias, localizadas no sítio arqueológico de Hatra, em Mosul, declarado patrimônio mundial pela Unesco. Os combatentes do Estado Islâmico seguem o salafismo, uma interpretação extrema do islamismo sunita, que proíbe a idolatria de estátuas e túmulos. Para Axel Plathe (2015), diretor do escritório da UNESCO no Iraque, esses grupos "querem destruir os símbolos da cultura do Iraque que não correspondam às suas crenças, mas também, mostrar seu poder. Estão dizendo: não respeitamos os valores que vocês têm e vamos destruí-los". Fonte: http://brasil.elpais.com/brasil/2015/02/26/internacional/1424955673 750395.html

${ }^{8}$ O período entre aspas é de Wiesenthal, 1970; cf Levi, 1986, p.3. apud ROSSI, 2010, p.33

${ }^{9}$ Adaptação do romance homônimo escrito por Ray Bradbury e publicado em 1953.
} 
Essa ilustração, além de emblemar o poder de resistência da memória marginalizada continuada pela transmissão oral ao longo de gerações, tal como analisado por Pollak, indica que a aparente ampliação das possibilidades de conservação e comunicação do saber pela expansão da memória exterior através da escrita, notavelmente após a invenção da prensa de Gutemberg, poderia potencialmente significar maiores mecanismos de controle e limitação do acesso ao conhecimento. Com efeito, desde a invenção do alfabeto fonético, quando se deu a passagem da tradição da oralidade à escrita, já havia na Antiguidade Clássica, principalmente na doutrina platônica, a preocupação com enfraquecimento da memória ${ }^{10}$ e do saber no espírito humano.

Levaria muito tempo para repetir tudo o que Thamus disse a Theuth em louvor ou crítica às várias artes. Mas quando chegaram às letras da arte da escrita, isto, disse Theuth, tornará os egípcios mais sábios e dar-lhes-á melhores lembranças; é um remédio específico tanto para a memória quanto para o espírito, ao que Thamus replicou: ó engenhosíssimo Theuth, o pai ou inventor de uma arte nem sempre é o melhor juiz da utilidade ou inutilidade de suas própria invenções para os que dela se servem. E, nesse caso, vós que sois o pai das letras, fostes, movido pelo amor paternal por vossos próprios filhos, levado a atribuir-lhes uma qualidade que não têm; pois essa vossa descoberta criará um esquecimento na alma dos estudantes, porque eles não se servirão da memória; confiarão nos caracteres escritos e exteriores e não se lembrarão de si mesmos. O específico que descobristes é um auxiliar não para a memória, porém para a reminiscência, e vós dais a vossos discípulos não a verdade, porém tão só a aparência de verdade; eles serão ouvintes de muitas coisas e nada terão aprendido; darão a impressão de serem oniscientes e, em geral nada saberão; serão uma companhia fastidiosa com aparência de sabedoria, sem a sua realidade. (Platão ${ }^{11}$ apud Mc Luhan, 1977 p. 49)

Benjamin (1994), também articula oralidade, memória e esquecimento. Para ele, a arte da narrativa relaciona-se ao compartilhamento de uma memória comum entre ouvinte e narrador, ou seja, é uma troca de experiências intergeracional, que permite a transmissão

\footnotetext{
${ }^{10}$ Aqui entendida como memória mnemônica, em oposição à memória mecânica

${ }^{11}$ Phaedrus, trad. de B. Jowett, 274-275.
} 
da tradição própria das sociedades pré-capitalistas. A fragmentação das formas de existência no ritmo acelerado do modo de produção das sociedades capitalistas impõe uma barreira comunicacional entre as gerações, levando à perda da experiência, ao esquecimento da tradição. Em "Sobre o conceito de História" (1994, p.224) Benjamin alerta que as únicas tradições mantidas do passado pela a narrativa histórica são as tradições dos vencedores. Ele usa a famosa alegoria do anão enxadrista que, escondido por debaixo da mesa, comanda um tabuleiro de xadrez através de um títere, para inserir a ideia de que os vencedores dominam os vencidos pelo espírito, instilando nestes últimos o sentimento de empatia com seus valores (bens culturais). Este fantoche é o materialismo histórico, que sempre irá vencer, desde que tenha como comandante a teologia (dito em termos marxianos, a ideologia de classe, que se apodera dos espíritos sem que ninguém se aperceba $)^{12}$. Benjamin enfatizou a importância de trazer à luz esse poderoso instrumento imperceptível de dominação, porém, em vez de dirigir a redenção revolucionária para o futuro, como proposto por Marx \& Engels (1998; 2009), direcionou sua práxis revolucionária ao passado, acreditando ser papel do materialista histórico "escovar a história a contrapelo" (1994, p. 225). Em Benjamin o passado é incompleto, fruto de um acordo entre as gerações passadas e as atuais. É essa incompletude que permite o caráter messiânico de resgate dos derrotados, que esquecidos pela história, clamam no presente pelo fim dos sofrimentos legados pelo passado. A crítica revolucionária de Benjamin é "um salto de tigre em direção ao passado" (1994, p.230), retirando o oprimido do tempo linear histórico que eternizou a herança de uma imagem para além das gerações.

Esquecimento e memória, todavia, não podem ser compreendidos sob um viés estritamente ideológico de uma interação entre dominantes e dominados. Huyssen (2004), por exemplo, fala de uma mudança na tônica de uma prática discursiva dedicada aos "futuros presentes" (2004, p.9), que caracterizou o paradigma da cultura modernista do início do século XX,

\footnotetext{
${ }^{12}$ MARX, Karl; ENGELS, Friedrich. A Ideologia Alemã. São Paulo: Expressão Popular, 2009.
} 
para o cuidado com os "passados presentes" (2004, p.9), que surge como um fenômeno cultural global a partir da década de 1980. Antes as memórias do século XX, marcadas pela Grande Depressão, por duas grandes guerras, pelo holocausto, destruição em massa e regimes autoritários, não se coadunavam com o ideal modernista de progresso. Mas então, o que teria determinado uma virada para uma obsessão memorialística, que se disseminou, sobretudo, com um amplo aproveitamento político da memória relacionada a violações de direitos humanos, justiça de transição, reparações públicas de períodos traumáticos como o holocausto e as ditaduras da América Latina? Independentemente das conexões sociais e políticas que tenham conduzido ao triunfo da memorialização, tal fenômeno, responde Huyssen (2004), não pode ser analisado prescindindose do papel das tecnologias de mídia como instrumentos de acesso à memória. A revolução causada pelas tecnologias de informação possibilitou a emergência de uma sociedade informacional interconectada em redes intensamente dinâmicas. A informação assume crescentemente um maior papel estratégico na nova configuração da ordem social e circula numa velocidade até então jamais imaginada (CASTELLS, 1999). A compressão do tempo-espaço provocada pelas novas formas organizacionais e novas tecnologias produtivas da acumulação flexível capitalista, contribui para o aperfeiçoamento da comunicação e do fluxo de informações (HARVEY, 1992).

Huyssen enfatiza então, que os valores da efemeridade, descartabilidade e instantaneidade produzem efeitos aceleradores nas formas modernas de pensar, sentir e de agir no mundo, que despertam no indivíduo a sensação cada vez maior de presenteísmo e medo do esquecimento. Assim, a volta ao passado através da memória configura uma estratégia de ancoragem numa realidade marcada por um tempo e espaço fragmentários cada vez mais inapreensíveis à experiência humana, porém a rememoração só pode acontecer de forma irreal e incompleta. Muitos críticos acusam a obsessão da memória de provocar o aumento da amnésia. 
O autor lembra que, muito próximo ao temor platônico do enfraquecimento da memória mnemônica pela criação da escrita, está a preocupação destes críticos (que seguiram a crítica de Adorno, segundo a qual, mercadorização é esquecimento), com uma espécie de "perda da consciência histórica" (HUYSSEN, 2004, p.18), tanto mais a memória esteja salvaguardada na mídia (imprensa, internet, aparelhos de informática). Assim, continua Huyssen, as novas políticas e tecnologias de informação transformam a memória em mercadoria consumível e "os interesses de lucro dos comerciantes de memória de massa parecem ser mais pertinentes para explicar o sucesso da síndrome da memória" (2004, p.23-24). Mas isso, apenas porque esse comércio atende a uma demanda de passado originada pela alteração da experiência do homem em seu "estar no mundo".

De um lado as novas tecnologias midiáticas operam uma transformação na percepção temporal que levam à perda referencial no presente (uma vez que este se torna passado numa velocidade cada vez maior), de outro, essa mesma tecnologia vende esse passado apaziguando uma instabilidade existencial, isto é, atenuando aquela sensação de "perda da consciência histórica". Mas como agora a memória inscreve-se na lógica da indústria cultural, muitas vezes temos acesso a uma memória apenas imaginada, que espetaculariza traumas históricos, como o Holocausto, que se tornou produto da indústria cultural através da produção de filmes, documentários, séries de TV. Essa percepção da memória como produto irá nos ajudar a compreender o papel da mídia enquanto "lugar de memória", como chamou Nora (1993). "Sabemos que a mídia não transporta a memória pública inocentemente; ela a condiciona na sua própria estrutura e forma" (HUYSSEN, 2004, p. 22-23).

As imagens são captadas segundo um padrão (...). Essas imagens compõem grandes acervos e podem ser adquiridas no mercado das agências internacionais produtoras de imagens e sons. A diferença estaria nas legendas e na fala dos apresentadores que, em várias línguas buscam traduzir o que as imagens daquela realidade desejaram expressar, no momento em que foram captadas, dando a elas um sentido, ou seja, localizando-as no contexto de abrangência de cada uma das emissoras. (COUTINHO, 2003, p. 50) 
De fato, a análise do tema aqui proposto também deve levar em consideração estes dois aspectos. O primeiro se refere à questão da velocidade e volatilidade da informação e seu papel decisivo na configuração das relações sociais da "pós-modernidade", fazendo com que o recurso à memória seja uma estratégia para o indivíduo se referenciar no mundo. O segundo é que, a lógica de seleção e preservação de conteúdo também está intimamente ligada à lógica do lucro (que se vê no tratamento da memória como negócio).

Importante destacar que a intenção aqui não foi realizar uma evolução histórica das teorias sociais de memória, nem privilegiar nenhuma delas, bem como não houve a pretensão de explorar uma "demonização ideológica" do significado de esquecimento. Memória e esquecimento constituem um processo dinâmico e dialético, que só pode ser compreendido enquanto tal, pela conjugação de diversas teorias de memória.

\subsection{Mídia e memória}

Os meios de comunicação são espaços privilegiados de produção, seleção e manutenção de memória ou, na concepção de Halbwachs e Nora, história, pois utilizam o termo em oposição à memória para distinguir um conteúdo controlado, produzido voluntária e deliberadamente nos "lugares de memória" (NORA, 1993), como arquivos, centros de documentação, bibliotecas. Enquanto "lugar de memória", que para Nora só pode ser definido assim quando há sentido material, simbólico e funcional (aura simbólica), os meios de comunicação são dotados de autoridade tanto pelo fato de produzirem, como de conservarem saberes e identidades. Os conteúdos conservados em seus centros de documentação podem ser acessados a qualquer tempo ao sabor da intencionalidade das edições que serão veiculadas. É neles que se encontram os "senhores da memória e do esquecimento", que como vimos em Le Goff, utilizam a prática da seleção 
de conteúdos, classificados entre o grupo daqueles que devem ser lembrados e o grupo daqueles que devem ser esquecidos. Uma forma de dominação que confere poder. Preservar é projetar efeitos para o futuro. Para Foucault (1985), a mídia obedece aos mecanismos da economia e do poder e cria assim as condições reais da opinião. A análise da genealogia do poder em Foucault assinala que as relações de dominação estão na origem do saber e este, em contrapartida, assegura a prática de um poder, de tal modo que nenhum saber pode ser neutro. Da mesma forma que o saber confere legitimidade ao poder (exteriorizado na especialização dos saberes), ele mesmo, constituído enquanto tal, é dotado de poder. Poder e saber produzem também a individualidade, que se caracteriza pela multiplicidade ordenada. O corpo adestrado, regulado, normatizado, interpretado, constrói o homem como ser individualizado, a um só tempo produto do poder e objeto do saber. A manutenção e aceitação do poder, segundo Foucault (1985), não se dá pela repressão com uso da força, mas porque ele produz saber, discurso e prazer.

Foucault e depois Bourdieu abordaram a intrínseca relação entre saberes, discursos, memória e poder. Os discursos de verdade, alerta Foucault, não podem existir sem poder e são mesmo produzidos por este. A verdade então não seria algo a ser encontrado, mas é fabricada em cada sociedade sob diferentes enunciados, com a mesma lógica de produção e reprodução, utilizando aparelhos de Estado, de informação, de educação. Nas sociedades capitalistas, o discurso científico é a matéria de validação da verdade e dos estabelecimentos que a produzem.

Daí decorre também o fato de que o ponto importante será saber sob que formas, através de que canais, fluindo através de que discursos o poder consegue chegar às mais tênues e mais individuais das condutas. Que caminho lhes permitem atingir as formas raras ou quase imperceptíveis do desejo, de que maneira o poder penetra e controla o prazer cotidiano - tudo isso com efeitos que podem ser de recusa, bloqueio, desqualificação, mas também, de incitação, de intensificação, em suma, as "técnicas polimorfas do poder" (FOUCAULT, 2006, p.18). 
Bourdieu (2004) também aborda a questão do poder simbólico representado nas estruturas de dominação das sociedades de classes. Entretanto, Bourdieu utiliza o termo "ideologia" para falar do instrumento de justificação a uma ordem que interessa à classe dominante. Foucault rechaça esse termo, pois para ele, a noção de ideologia se opõe àquilo que seria a verdade, e em seu pensamento os discursos não são verdadeiros nem falsos, mas a verdade seria um conjunto de convenções avesso ao conjunto do que se convencionou chamar de falso. Foucault não pensa a dominação à luz do par inextricável "ciência/ ideologia", mas do eixo "verdade/ poder". Em Bourdieu, ideologia é o mecanismo de dominação que se efetiva por meio do "poder simbólico", um poder legitimado capaz de manter o status quo de uma ordem social de forma dissimulada. O sociólogo considera os sistemas simbólicos, estruturas estruturadas e estruturantes (BOURDIEU, 2004), que, como instrumentos de conhecimento e comunicação, ao mesmo tempo em que constroem a realidade, são por ela construídos. O poder simbólico destes sistemas se autorrenova para continuar legítimo e então reitera outras formas de poder, disfarçando a violência simbólica da dominação de classes. Assim, o poder e autoridade conferidos à mídia, por exemplo, são tanto maiores quanto mais as instituições de comunicação são competentes em se mostrarem neutras em relação aos conteúdos por elas divulgados e quanto mais verdadeiros parecerem estes conteúdos.

Ao analisar os primórdios da imprensa carioca, Barbosa (2000) mostra que as ideias de isenção, imparcialidade, neutralidade e veracidade aparecem como agregadoras de valor a partir de 1880 nos principais periódicos da então capital da República, imersa nas preocupações com a concretização dos ideais positivistas que eram a palavra de ordem da época. A imprensa, a partir de então, cumpriu o papel de unificar discursos de ordem e progresso que interessavam aos grupos dominantes, através da difusão de valores, normas, costumes, unindo toda a sociedade em torno deles. Enquanto um meio que literalmente escreve a história, a imprensa 
absorveu desta, seus ideais de verdade e imparcialidade, adquirindo poder através do discurso que ajudou a consolidar.

A despeito de se venderem como instituições apartidárias e imparciais, Barbosa (2000) acusa os jornais dos primeiros anos da República de se ligarem a grupos de poder político por meio de favorecimento. Era comum, na época, diversos periódicos receberem verbas do Governo (prática corrente no período de Prudente de Morais e Campos Sales) em troca de matérias em sua defesa. Por outro lado, quanto mais eficazes em dissimular o cunho tendencioso de suas divulgações, isto é, quanto mais um jornal era reconhecido por sua neutralidade ideológica, mais o grupo de poder interessado em suas publicações reforçava seu prestígio.

Como um estado maior intelectual de partido orgânico, supostamente apolíticos e reafirmando sua própria independência, os jornais atuam como uma força dirigente superior, mesmo que em função de objetivos específicos se liguem a um ou a outro grupo (BARBOSA, 2000, p.150).

Assim é que, o jornalismo, ao representar a imparcialidade e neutralidade, é a própria expressão da verdade, dotando o jornal impresso de poder documental. Cada vez mais a imprensa procurou oferecer ao seu público "provas" da veracidade das informações que veicula. Por isso, a imagem da fotografia aliada ao texto impresso passa a ser largamente utilizada ainda no início do século XX com o propósito de revelar a autenticidade necessária ao conteúdo do jornal, de forma a lhe agregar valor (BARBOSA, 2000). Imagem e texto possuem a qualidade documental da realidade necessária à memória.

Televisão e imprensa se fundam no mesmo caráter de meios da verdade. Ambas possuem o recurso da imagem como reveladora da realidade. São "neutras" à medida que são visuais. A sociedade ocidental funda-se na concepção dessacralizada do "ver para crer", remetendo à ideia publicitária de que "uma imagem vale mais do que mil palavras". 
Assim como Le Goff, Mc Luhan (1977) opôs o mundo visual da sociedade ocidental alfabetizada ao mundo oral mágico, como o das tribos africanas rurais. Para ele, "como o mundo da audição é um mundo hiperestético e quente, e o da visão, relativamente frio e neutro, o ocidental afigura-se ao povo da cultura auditiva como criaturas tão frias como os peixes" (1977, p.41). Enquanto o homem oral conserva a sacralidade mágica da concepção auditiva, o alfabeto fonético impôs a experiência visual como forma de consciência humana, conduzindo à dessacralização do mundo ocidental. É a "experiência do alfabeto fonético, que arranca as sociedades do mundo do espaço e tempo 'sagrados' para o espaço e tempo profanos ou destribalizados do homem civilizado e pragmático" (MC LUHAN, 1977, p. 84). Mas tanto para Le Goff, quanto para Mc Luhan, foi a palavra impressa, com a invenção da tipografia, a responsável pela grande transformação da consciência civilizatória ocidental. A tecnologia da imprensa dá ao homem a posse de seu saber através de uma perspectiva visual, uniforme e exata. Os textos manuscritos não tinham grande possibilidade de difusão para a criação de público em âmbito nacional. A nação só foi possível depois da impressão. É com a cultura da palavra impressa que surge o indivíduo, o público, o Estado, a nação, o pensamento científico secularizado, desinteressado e objetivo. É ela que fragmenta a continuidade temporal das narrativas orais, tal como observou Benjamin (1994), para inaugurar uma narrativa artificial fragmentada temporal e espacialmente. A imprensa é responsável por uma revolução na forma de transmissão da memória. O leitor pode ter acesso a uma grande quantidade de memória coletiva, porém não pode mais dominá-la como na tradição oral (LEROI-GOURHAM apud LE GOFF, 1994).

Doravante, o que não é visível e que, portanto, não tem uma imagem que o represente, passa a não existir ou, ao menos, a ter existência precária. As próprias imagens não seriam quaisquer imagens, mas aquelas que pudessem expressar-se segundo um programa muito bem urdido, sobretudo a partir da utilização das técnicas de perspectiva. (COUTINHO, 2003, p. 52) 
A imprensa de prelo ou dos telejornais, ao utilizar essencialmente o recurso visual, reafirma a lógica pragmática do homem ocidental contemporâneo. Essa lógica é a da verdade enquanto documento, expressa em formas visuais. Com efeito, Le Goff (1994) já havia alertado sobre a idéia de vivermos a cultura do documento, que triunfa com a escola positivista. "Não há notícia histórica sem documentos (...) pois se dos fatos históricos não foram registrados documentos ou gravados ou escritos, aqueles fatos perderam-se" (LEFEBVRE apud LE GOFF, 1994, p. 539).

“O que o jornal procura difundir é a realidade construída, mas apresentada como verídica.” (Barbosa, 2000, p.130). Esse poder simbólico da imprensa relaciona-se com a classe dominante, mas se apresenta como interesse universal, uma vez que a lógica de valorização de seu discurso (um discurso que tem o status da cultura do impresso ampliada para todos meios jornalísticos) é aceita por toda a sociedade. Dessa forma, o jornalismo faz um enquadramento de memória, no sentido tratado por Pollack (1989), forjando a memória coletiva em razão de seus interesses. É através desse poder simbólico do jornalismo, com as características necessárias de objetividade, imparcialidade e finalidade de documento, características estas reconhecidas por toda a sociedade, que a imprensa se estrutura e é estruturada enquanto forma legítima de informação. ${ }^{13}$

Vimos que Foucault defende a ideia de que os meios de comunicação criam as condições de opinião, forjando a memória coletiva, e que o monopólio do saber dá origem às relações de poder, sendo ele mesmo constituinte e constituído por este último. Barbosa (2000) analisa que ao dominar o conhecimento do acontecimento inédito, o jornalista, mais do que admiração, adquire poder, ao saber da atualidade antes do público, e ser o intermediador entre a mensagem e o receptor. Além disso, o jornalista

\footnotetext{
${ }^{13}$ Em "A Ideologia Alemã" (2009), Marx e Engels enfatizam que a classe dominante, como detentora dos meios de produção material, é detentora também dos meios de produção espiritual, motivo pelo qual suas ideias predominam sobre as da classe dominada. Para garantir a estabilidade de sua dominação, precisa "apresentar o seu interesse como o interesse universal de todos os membros da sociedade, ou seja, na expressão ideal (ideell): a dar às suas ideias a forma da universalidade, a apresentá-las como as únicas racionais e universalmente válidas”. (p. 69)
} 
encarna o ideal de isenção, estando ele habilitado a julgar com imparcialidade.

Em Sobre a Televisão, Bourdieu (1997), observa que os jornalistas utilizam "óculos" através dos quais selecionam e constroem o que vêem, e sua seleção se baseia no sensacional, no extraordinário, que muitas vezes pode ser quotidiano para outros e vice-versa.

insensivelmente a televisão que se pretende um instrumento de registro, torna-se um instrumento de criação da realidade. Caminha-se cada vez mais rumo a universos em que o mundo social é descrito-prescrito pela televisão. A televisão se torna o âmbito do acesso à existência social e política" (BOURDIEU,1997, p.29)

O jornalismo, para se manter nestes moldes, precisa dispor de outras estruturas de poder com as quais estabelece uma relação onde cada elemento reafirma a posição do outro, de modo a não permitir que o equilíbrio dessas forças de sustentação seja quebrado por outra paralela e transgressora, que não comunga dos códigos que sustentam essa interação.

É enquanto instrumentos estruturados estruturantes de comunicação e de conhecimento que os "sistemas simbólicos" cumprem a sua função política de instrumentos de imposição ou de legitimação da dominação, que contribuem para assegurar a dominação de uma classe sobre a outra (violência simbólica), dando o reforço de sua própria força às relações de força que as fundamentam e contribuindo assim, segundo a expressão de Weber, para a "domesticação dos dominados". (Bourdieu, 2004, p.11).

Assim, a seleção de notícias promovida pelo jornalista, privilegia aspectos jurídicos, políticos e econômicos segundo critérios de “importância” dessas mensagens ao meio social. Quando um jornalista seleciona, dentre tantos assuntos do dia, aquele que merece virar notícia, está ao mesmo tempo selecionando aquilo que não deve virar memória coletiva, no sentido analisado por Halbwachs, isto é, a memória viva de um conjunto simbólico compartilhado socialmente. “(...) Toda decisão de comunicar qualquer coisa é, ao mesmo tempo, uma decisão de excluir tudo o mais" (Ortriwano, 1985, p.108). 
Entre a dialética lembrar e esquecer, os jornais constituem-se como um dos senhores da memória da sociedade, aumentando seu campo de atuação e, sobretudo, o seu poder. É preciso considerar ainda que o jornalista, ao selecionar fatos, relegar outros ao esquecimento, escolher a forma de sua narrativa e ao definir o lugar na página a ser ocupado pelo texto, dirigindo um olhar subjetivo sobre o acontecimento, mantém como essencial nesse trabalho a dialética lembrar e esquecer. Aos relatos que devem ser perenizados, imortalizados pela prisão da palavra escrita, contrapõem-se outros que devem ser relegados ao esquecimento (SOUTO, 2002, p.31)

Os meios de comunicação exercem assim, papel fundamental na dinâmica memória/ esquecimento, conjuntamente com os aparelhos de Estado, educação, atuando de forma a renovar discursos mantendo sua posição estratégica de dominação na ordem social vigente.

Podem se constituir enquanto veículos que agem na difusão de discursos de outros grupos de poder (governo, partido, empresários), ou como propagadores de uma memória que atende a seus próprios interesses, funcionando como um sistema de poder simbólico, laico, apartidário, não oficial, que produz discursos representados no conjunto de práticas sociais. 


\section{DIREITO À MEMÓRIA}

A taxa é zero, o juro é alto/Vamos conversar/ O pagamento, ressarcimento/Vamos negociar/ Aquela dívida de uns anos atrás/ Está bem viva, você não lembra mais.

(Composição de Tonho Crocco e Ultramen, também cantada pelo grupo O Rappa)

Como visto até agora, enquanto processo de conservação e circulação de ideias, imagens e experiências vividas anteriormente, a memória permite ao indivíduo conhecer a si próprio e o grupo ao qual pertence. É ao mesmo tempo o liame entre o sujeito e a coletividade. A ideia de pertencimento fornecida pela memória possibilita a ancoragem da consciência individual no mundo, delineando a identidade e a representatividade social. Tem dimensão psicológica e social, individual e coletiva. A memória se configura então como uma verdadeira necessidade fundamental, motivo pelo qual é tratada por estudiosos do direito que se debruçam sobre o tema, como direito fundamental ${ }^{14}$.

Deve-se reconhecer ao indivíduo e à coletividade o direito à preservação dos sentidos de sua existência, genericamente chamado de direito à memória, revestido do status de fundamentalidade porque indispensável à existência digna do ser humano. O seu exercício compreende dois aspectos principais: o primeiro, de aprendizagem das experiências sociais passadas, que servem de orientação e base para a construção de um futuro melhor; e em segundo lugar, a formação da consciência de pertença do indivíduo ao grupo (identidade cultural), fundamental para sua inserção política e para o exercício efetivo de sua cidadania. (DANTAS, 2008. p. 19-20)

\footnotetext{
14 José Afonso da Silva destaca a dificuldade de sintetizar o conceito, uma vez que sofreu várias transformações ao longo da história e envolve muitas terminologias. Há várias expressões usadas em sentido sinônimo dentre as quais "direitos humanos", "direitos fundamentais" e "direitos do homem" são exemplos. Canotilho (2010) distingue direitos do homem, de direitos fundamentais. Os primeiros seriam direitos válidos às pessoas de todos os povos a qualquer tempo, pois decorrem da própria natureza humana, enquanto os segundos seriam os direitos jurídico-institucionais reconhecidos num dado ordenamento jurídico. Na mesma direção, Ingo Sarlet (2010) diferencia direitos humanos de direitos fundamentais. Direitos humanos têm viés jusnaturalista, enquanto os direitos fundamentais refletem um caráter positivista, perspectiva esta adotada pela nossa Constituição de 1988.
} 
Pela expressão “direitos fundamentais do homem”, José Afonso da Silva (2009), inspirado por Pérez Luño, entende contemplados os princípios que orientam a compreensão de mundo e ideologia política reconhecidos num dado ordenamento jurídico. Também têm elevado grau de positividade através das garantias jurídicas que lhes dão concretude. Referem-se às condições de realização e sobrevivência do homem, decorrentes da necessidade de igualdade, liberdade e dignidade humana. Compreende-se ainda por essa expressão, uma "limitação imposta pela soberania popular aos poderes constituídos do Estado que dela dependem” (SILVA, 2009 p.178). José Afonso classificou esses direitos em 6 grupos gerais: (1) individuais (expressos no art $5^{\circ} \mathrm{CF} / 88$ ); (2) direitos à nacionalidade (art.12); (3) direitos políticos (arts. 14 a 17); (4) direios sociais (arts $6^{\circ} \mathrm{e}$ 193 e ss); (5) direitos coletivos (art. 5\%); (6) direitos solidários (art. $3^{\circ} \mathrm{e}$ 225). Mesmo que não positivados, esses direitos tem plena aplicabilidade, de modo a realizar sua eficácia material. A Constituição Federal de 1988 consagrou em seu art. $5^{\circ}, \S 2$, verdadeira cláusula de abertura para reconhecimento material de direitos e garantias fundamentais que, apesar de não expressos em seu texto, se integram harmonicamente aos seus postulados, tanto mais visem realizar o princípio da dignidade da pessoa humana. Assim, as fontes e garantias dos direitos podem ser expressas (art. $5^{\circ}$, I a LXXVIII), decorrentes dos princípios da própria Constituição (alguns autores chamam de implícitas) ou decorrentes de tratados e convenções internacionais ratificados pelo Brasil.

Paulo Bonavides (2011), entende que os direitos fundamentais se manifestam em cinco gerações. A primeira geração foi a dos direitos da liberdade (civis e políticos), com primazia do indivíduo. A segunda foi a dos direitos da igualdade, cuja tônica é social (sociais, culturais, econômicos e coletivos). Os direitos de terceira geração seriam os da solidariedade, como o direito ao desenvolvimento. Os direitos fundamentais de quarta geração são o direito à democracia, à informação e ao pluralismo. Os direitos de quinta geração se caracterizam pelo direito à paz. 
Por sua universalidade, esses direitos alcançam todos os ramos do direito. Entre tantos outros abrangidos por eles, se encontram: (i) o direito à memória, isto é, o direito fundamental de acesso, utilização, preservação e transmissão de bens culturais (materiais e imateriais) que integram o patrimônio cultural de uma sociedade; (ii) o direito à verdade, que é o direito fundamental de se ter acesso às informações verdadeiras que sejam de interesse coletivo. Os direitos à verdade e à memória não estão expressos no texto constitucional, mas sua fundamentalidade pode ser depreendida de sua harmonização com os valores dos princípios fundamentais protegidos pela Constituição de 1988 , conforme disposto em seu art. $5^{\circ}, \S 2$.

No Brasil, o direito à memória é abordado privilegiadamente sob duas perspectivas. A primeira diz respeito à memória enquanto bem cultural, tratada à luz dos direitos culturais (abarcados pelo direito ambiental). A segunda diz respeito ao binômio "direito à memória e à verdade", que se relaciona à justiça de transição e aos direitos humanos. Cada uma será analisada a seguir, separadamente, em tópico próprio. Veremos ainda, que o tratamento legal dado à memória midiática, que é o que nos interessa mais diretamente, é atravessado por aspectos presentes nas abordagens de memória vistas até então. Embora o direito à memória tenha também uma dimensão individual, que integra os direitos da personalidade, importa aqui tratar de sua dimensão coletiva.

\subsection{Memória como Patrimônio Cultural}

Em "Direitos Culturais como Direitos Fundamentais", Francisco Humberto Cunha Filho (2000) definiu o conceito de cultura como direito fundamental por se relacionar à dignidade da pessoa humana. Cultura nesse sentido é a produção humana ligada a ideal de aprimoramento. Direitos culturais seriam a arte; memória coletiva; fluxo de saberes.

Ë possível encontrar direitos culturais em todas as dimensões de direitos fundamentais. A Declaração Universal dos Direitos Humanos de 1948 consagrou como direito de todas as pessoas e responsabilidade dos Estados-membros da ONU a satisfação dos direitos culturais (cláusula 
genérica) e em particular a participação na vida cultural da comunidade, de fruir as artes, participar do progresso científico e benefícios q dele resultam. O direito à memória faz parte dos direitos culturais, que por sua vez estão abarcados pelos direitos ambientais. De acordo com José Afonso (2004), meio ambiente não se limita aos aspectos naturais da vida, mas contempla também os aspectos artificiais, como o trabalho e a cultura. Meio Ambiente é tudo aquilo que envolve a relação do homem com a natureza. Cultura e identidade fazem parte disso, portanto, o meio ambiente deve ser entendido na combinação entre os arts. 225, 215 e 216 da Constituição Federal de 1988.

Por suas dimensões individual, coletiva, intergeracional e plural, o direito fundamental à memória pode ser considerado de primeira, segunda, terceira ou quarta dimensão. Na análise de Fabiana Dantas (2010), o direito fundamental à memória pode ser encontrado no conjunto de direitos culturais (art. 215) ou de forma dispersa e indireta nos direitos individuais consolidados nos arts. 5 (IX, XXVII, XXVIII e LXXIII), 202, § 2 e $\S 3$, como valor econômico, nos arts. 219 e 221 ou ainda como dever difuso nos 227 e 231. No âmbito internacional o fundamento dogmático ao direito à memória se justifica na Convenção para a Proteção do Patrimônio Mundial, Cultural e Natural (Unesco, 1972), da qual o Brasil é parte. Seu art. $4^{\circ}$ dispõe que todos os seus Estados membros se obrigam a reconhecer que "a identificação, proteção, conservação, valorização e transmissão às gerações futuras do patrimônio cultural e natural referido nos artigos $1 .^{\circ}$ e $2 .^{\circ}$ e situado no seu território constitui obrigação primordial”. Embora esta Convenção defina patrimônio cultural em seu aspecto estritamente material, como monumentos, locais arqueológicos, tem o grande mérito de consagrar o princípio da solidariedade intergeracional, que também é princípio informador do direito ambiental, sob o qual estão albergados os direitos culturais e, por conseguinte, o direito à memória.

Dantas (2010) elenca os princípios que tutelam o direito à memória, classificando-os como gerais, específicos e complementares. Dentre os 
princípios gerais estão: (i) o da dignidade ${ }^{15}$ da pessoa humana (à medida que o direito à memória permite a integração do homem a seu ambiente cultural, potencializa o desenvolvimento humano subjetivo e coletivo); (ii) autodeterminação dos povos, isto é, respeito à legitimidade de um povo sobre seu próprio destino (o direito à memória permite a noção de pertencimento através da identidade cultural); (iii) não-discriminação; (iv) desenvolvimento sustentável (compromisso de transmissão de bens culturais a gerações futuras); (v) princípio democrático (o direito à memória depende de uma seleção democrática de conteúdos plurais); (vi) princípio da cooperação (toda a sociedade, poder público ou iniciativa privada deve juntar esforços para a preservação de bens ambientais); (vii) função social (o patrimônio cultural deve ser pensado para beneficiar toda a coletividade). Ao lado destes ainda se encontram os princípios sistêmicos da unidade, imperatividade e supremacia da Constituição.

Os princípios específicos compreendem: (i) princípio da multidiversidade (promove a diversidade cultural); princípio da seletividade, pelo qual se escolhe o que deve ser lembrado ou esquecido; (ii) princípio da conservação das opções, que impõe a preocupação de se legar às gerações futuras mesmo o bem cultural cujo valor não é reconhecido pela geração atual); (iii) cooperação cultural com equilíbrio (a transmissão de bens culturais não deve ser imposição de valores); (iv) princípio da equidade intergeracional (visa evitar danos irreparáveis ao bem cultural, de modo a preservar o interesse das próximas gerações); (v) princípio da solidariedade intergeracional (o compromisso das decisões do presente em considerar seus efeitos sobre as gerações futuras); (vi) princípio da igualdade material (permite a todas as pessoas participarem do bem comum).

\footnotetext{
${ }^{15}$ Assim definido por Dantas (2008. p.66) após o cotejamento do pensamento de Hanna Arendt (1983), Clément Rosset (1989) e Fernando Ferreira dos Santos (1999): “A dignidade seria, então, a construção de direitos subjetivos capazes de garantir a suficiência dos recursos e bens à satisfação das necessidades dos indivíduos em cada um dos aspectos acima citados - labor, trabalho e ação política, que serão atendidas em conformidade aos hábitos culturais de cada povo, determinando o seu modus vivendi.".
} 
Finalmente, os princípios complementares são os da prevenção (evita danos ao bem cultural), precaução (evita riscos potenciais de dano ao patrimônio cultural), conservação (o bem não deve ser descontextualizado de seu sentido) e do uso compatível (o uso do bem deve ser compatível com sua finalidade e com as exigências de sua preservação).

Na Constituição Federal de 1988, o patrimônio cultural dá suporte ao direito à memória. Segue a definição do art. 216:

\footnotetext{
Constituem patrimônio cultural brasileiro os bens de natureza material e imaterial, tomados individualmente ou em conjunto, portadores de referência à identidade, à ação, à memória dos diferentes grupos formadores da sociedade brasileira, nos quais se incluem:

I - as formas de expressão;

II - os modos de criar, fazer e viver;

III - as criações científicas, artísticas e tecnológicas;

IV - as obras, objetos, documentos, edificações e demais espaços destinados às manifestações artístico-culturais;

$\mathrm{V}$ - os conjuntos urbanos e sítios de valor histórico, paisagístico, artístico, arqueológico, paleontológico, ecológico e científico.
}

A legislação sobre patrimônio cultural no Brasil data da década de 1930, como parte de um processo modernista de integração e construção da identidade nacional. $\mathrm{O}$ patrimônio cultural aqui considerado, apenas se expressava por sua forma de pedra e cal, isto é, obra monumental. Mário de Andrade, em 1936, chegou a propor em um projeto de lei que o patrimônio cultural abrangesse a culinária brasileira, cantos, folclores. Porém, foi a Constituição de 88 que ampliou essa definição, passando a compreender o patrimônio cultural em sua dimensão material e imaterial, de acordo com o conjunto de bens culturais determinado (OLIVEN, 2003, p. 77-80). Em seu aspecto material, o patrimônio cultural pode ser considerado o conjunto de objetos móveis (como os acervos bibliográficos ou documentais) e imóveis (sítios arqueológicos, paisagísticos, entre outros) tangíveis e representativos de cultura, que informam seu contexto histórico. Já na perspectiva imaterial, patrimônio cultural seria um conjunto de bens intangíveis: práticas sociais (saberes, modos de fazer); celebrações; expressões culturais (dança, 
música); lugares que tenham dimensão simbólica para a reprodução de práticas coletivas, como mercados e feiras.

A “Convenção da Unesco para a Salvaguarda do Patrimônio Cultural Imaterial” (2003), ratificada pelo Brasil em 2006, definiu o patrimônio cultural imaterial como "as práticas, representações, expressões, conhecimentos e técnicas - com os instrumentos, objetos, artefatos e lugares culturais que lhes são associados - que as comunidades, os grupos e, em alguns casos os indivíduos, reconhecem como parte integrante de seu patrimônio cultural." ${ }^{16}$

O tombamento e o registro são os instrumentos legais para a preservação do patrimônio cultural previstos na Constituição, embora não esgotem as formas legais de preservação dos bens de valor cultural. Preservação é um conceito genérico que compreende as ações do Estado para conservação da memória e valores da nação, o que além da legislação, engloba atos administrativos, como as ações de fomento. De fato, a Constituição de 88 estabelece no art. $216 \S 1^{\circ}$, que além de inventários, registro e tombamento, o Poder Público poderá proteger o patrimônio cultural por meio de "outras formas de acautelamento e preservação". O art. 23, III, IV, V, dispõe sobre a competência comum entre os entes de todas as esferas da federação para a proteção cultural. Já o art. 24, VII, VIII, IX, determina a competência legislativa concorrente entre União, Estados e Distrito Federal, cabendo à União a edição de normas gerais $\left(\S 1^{\circ}\right)$ e aos entes Estaduais a competência legislativa suplementar. Se a competência executiva é concorrente, na prática, o que irá determinar a qual ente cabe a proteção de um bem cultural, é seu grau de interesse. Se o bem for de interesse nacional, caberá à União, se de interesse regional, aos Estados, se o interesse for local, caberá aos Municípios (CASTRO, 1991).

O tombamento é o instrumento de preservação do patrimônio cultural material que seja de interesse da memória coletiva (bens que

16

http://portal.iphan.gov.br/portal/montarPaginaInicial.do;jsessionid=DADB88030F9789747A04CA D32ECDE0A3 
tenham valor histórico, cultural, arquitetônico, ambiental e afetivo para a coletividade), regido pelo Decreto-lei n 25/ 37. É um ato administrativo exercido por todas as esferas do Poder Público. Qualquer cidadão ou instituição pública é legitimado à iniciativa de abertura do processo de tombamento, que consiste em inscrever em livro próprio, bem móvel ou imóvel, público ou privado, isolado ou considerado em conjunto, com a finalidade de protegê-lo, de modo a impedir a sua destruição ou descaracterização. O IPHAN é responsável pelo tombamento no nível federal. O Decreto-lei n 25/ 37 estabelece como critério seletivo para bens naturais, os sítios e paisagens de feição notável ou a indústria humana. Para bens culturais os critérios de tombamento são o excepcional valor para a História do Brasil (mais interesse público), excepcional valor arqueológico, etnográfico e artístico.

O processo de tombamento, após avaliação técnica preliminar, é submetido à deliberação das unidades técnicas responsáveis pela proteção aos bens culturais brasileiros. Caso seja aprovada a intenção de proteger um determinado bem, seja cultural ou natural, é expedida uma notificação ao seu proprietário. Essa notificação significa que o bem já se encontra sob proteção legal, até que seja tomada a decisão final, depois de o processo ser devidamente instruído, ter a aprovação do tombamento pelo Conselho Consultivo do Patrimônio Cultural e a homologação ministerial publicada no Diário Oficial. O processo é concluído com a inscrição no Livro do Tombo e a comunicação formal do tombamento aos proprietários. ${ }^{17}$

O Registro de Bens Culturais de Natureza Imaterial (instituído pelo Dec. 3551/ 2001) é o instrumento para preservação de bens intangíveis. Por ele, as manifestações culturais imateriais são inscritas em livro próprio, de acordo com sua categoria. Constitui-se de 4 livros: Livro de Registro e saberes II Livro de Registro das celebrações III - Livro de Registro das Formas de expressão IV - Livro de Registro dos Lugares.

17 http://portal.iphan.gov.br/portal/montarPaginaSecao.do?id=17738\&sigla=Institucional\&retorno=p aginaInstitucional 
O inventário e a catalogação permitem o mapeamento dos bens culturais através de metodologia própria, revelando-os ao Poder Público (à memória oficial).

O Inventário Nacional de Referências Culturais (INRC) é uma metodologia de pesquisa desenvolvida pelo IPHAN para produzir conhecimento sobre os domínios da vida social aos quais são atribuídos sentidos e valores e que, portanto, constituem marcos e referências de identidade para determinado grupo social. Contempla, além das categorias estabelecidas no Registro, edificações associadas a certos usos, a significações históricas e a imagens urbanas, independentemente de sua qualidade arquitetônica ou artística. ${ }^{18}$ (grifo nosso)

Diante do exposto até agora, não fica difícil compreendermos que o delineamento do que é patrimônio cultural é sempre problemático. Para que haja o reconhecimento de um bem cultural, este deve corresponder à ideia de identidade, memória e ação dos grupos formadores da sociedade brasileira. Porém, como é possível delimitar qualitativa e quantitativamente esses grupos, bem como suas memórias a serem salvaguardadas do esquecimento? Se o critério for o da matriz étnica, já identificamos pelo menos um nó górdio: além da diversidade de tribos indígenas existentes no Brasil e das tribos africanas trazidas cá, nosso país foi marcado por um intenso fluxo migratório de europeus e asiáticos. Há um enorme conjunto de memórias coletivas formadoras da identidade nacional. $\mathrm{O}$ conceito constitucional de patrimônio cultural é restritivo porque antecedido e determinado pelo interesse legitimado do Poder Público em preservar um bem. Embora haja abertura à comunidade para participar desse processo, o poder de decisão é ato discricionário do Estado, embora adstrito a uma "metodologia de pesquisa desenvolvida" por órgão público, que confere ao ato um caráter de "objetividade" e "isenção". O conteúdo do Patrimônio Cultural é construído pelo Estado no exercício de seu poder discricionário no âmbito da atividade administrativa, segundo interpretações valorativas de conceitos normativos indeterminados. Por isso é preciso também

\footnotetext{
${ }^{18}$ http://portal.iphan.gov.br/portal/montarPaginaSecao.do?id=13493\&retorno=paginaIphan
} 
percebê-lo a partir das relações de poder inscritas na sociedade e projetadas em narrativas e representações (DANTAS, 2008).

O Dec-Lei 25/ 37 faz referência a "fatos memoráveis" e de “excepcional valor” como requisitos para seleção de preservação cultural. A competência para avaliar o que se enquadra nesses termos, só pode ser reconhecida naqueles que detêm o saber técnico, científico, histórico e artístico. O patrimônio cultural é assim consagrado por discursos de autoridade. (CHAGAS, 2003, p.104). Os discursos de saber, como já supracitado em Foucault (1985), ou discursos competentes, como propõe CHAUÍ (1982), produzem poder e por isso devem ser submetidos a critérios objetivos de aferição, como a metodologia de pesquisa. Contudo, adverte Chagas, mesmo esses critérios não isentam o privilégio por uma política ideológica:

A política federal de preservação do patrimônio histórico e artístico se reduziu praticamente à política de preservação arquitetônica do monumento de pedra e cal. O levantamento sobre a origem social do monumento tombado indica tratar-se de: a) monumento vinculado à experiência vitoriosa da etnia branca; b) monumento vinculado à experiência vitoriosa da religião católica; c) monumento vinculado à experiência vitoriosa do Estado (palácio, fortes, fóruns etc) e na sociedade (sede de grandes fazendas, sobrados urbanos, etc) da elite política e econômica do país (FALCÃO, 1984, p. 28 apud CHAGAS, 2003, p.104.) $)^{19}$

As políticas públicas de preservação promoveram tradicionalmente signos representativos do poder constituído, oferecendo à nação uma imagem de unidade harmoniosa através do discurso de identidade nacional, capaz de escamotear as divisões e contradições internas. A unificação nacional é um artifício discursivo para representar a diversidade como unidade. (HALL, 2006). Porém, ainda que se reconheça a diversidade na unidade, como faz o art. 216 da Constituição ao se referir a "diferentes grupos formadores da sociedade brasileira", trata-se de uma diversidade ordenada, no sentido formulado por Foucault, como visto no primeiro capítulo, que obedece a uma lógica de recorte pré-constituída.

\footnotetext{
${ }^{19}$ FALCÃO, J. A. Política cultural e democracia. A preservação do patrimônio histórico e artístico nacional. In: MICELI, S. (org.) Estado e cultura no Brasil. São Paulo: Difel, 1984.
} 
A prática e o discurso dominantes, como se sabe, estão encarregados de criar em todos os membros da sociedade, o sentimento de que fazem parte dela da mesma maneira, e que a contradição não existe, ou melhor, a contradição deve aparecer como simples diversidade ou como diferentes maneiras, igualmente legítimas, de participar da mesma sociedade. (CHAUÍ, 1982, p. 42)

A determinação do que é patrimônio cultural se inscreve no sistema simbólico que dispõe de instrumentos para legitimação da dominação, através de estruturas de comunicação e conhecimento. A atribuição de valor está a serviço do poder simbólico que hierarquiza os interesses sociais de acordo com uma lógica de dominação ordenadora da vida social. A forma de delimitação da diversidade cultural, definida pela norma jurídica e fruto de um ato administrativo, pode revelar o exercício de uma violência simbólica para imposição do que se quer fazer ver (BOURDIEU, 2004). Benjamin (1994 p. 225) também já havia abordado os bens culturais como produtos (“despojos”) de dominação que estabelecem laços de empatia entre vencedores e vencidos. É essa herança que, transmitida através das gerações, permite a manutenção das relações de poder. Do poder, nasce a tradição, da tradição, o poder renasce.

Evidentemente, a discricionariedade dos atos administrativos do Estado não está livre de controle. Este é desempenhado pelo poder judiciário, que, investido dessa função, pode tanto reconhecer o valor cultural de um bem não declarado assim pelo poder público, quanto determinar o que pode ou não ser preservado. No Recurso Especial $n^{\circ}$ 147.949-MG, o STJ entendeu ser possível questionar juridicamente o valor de um bem cultural, para efeito de anulação, manutenção ou determinação de seu tombamento, desde que tal decisão se dê no curso de procedimento ordinário ou desapropriação (que exige dilação probatória com prova pericial). Outro exemplo significativo da atuação do judiciário nesse sentido, foi o julgamento do Recurso Extraordinário $\mathrm{n}^{\circ}$ 153531-SC que, interposto pela Associação amigos de Petrópolis e outras entidades ligadas à proteção dos animais, pleiteou a reforma da decisão do Tribunal de Santa Catarina que não deu provimento a ação civil pública na qual o Estado de 
Santa Catarina foi demandado a coibir a manifestação cultural conhecida como "Farra do Boi", com base no art. $225 \S 1^{\circ}$, VII, CF/88. O STF entendeu pelo provimento do Recurso, proibindo a Farra do Boi por entender que o referido acórdão violava o dispositivo constitucional alegado. Prevaleceu a opinião de que os direitos culturais, para realização da cidadania e dignidade da pessoa humana, devem ser exercidos em harmonia com os valores que visam a promoção de uma sociedade livre, justa e solidária. Em voto vencido, o Ministro Maurício Corrêa defendeu que a Festa trata-se de manifestação tradicional da cultura regional configurada como patrimônio cultural imaterial e deve ser garantida em obediência ao art. $215 \S 1^{\circ} \mathrm{CF} / 88$. Ao Estado de Santa Catarina restaria apenas coibir os excessos para evitar a crueldade aos animais, não cabendo a ele ou ao STF impedir a continuidade de um costume cultural (DANTAS, 2008). Podemos inferir, portando, que a atuação da justiça, ainda que para ponderar os limites do poder público sobre a decisão do que seria um bem de valor cultural, não é isenta de relevantes controvérsias.

O importante a ser destacado é que o exercício da representação simbólica de grupos, das consciências sociais, realizado através da seleção memorialística e do domínio dos meios de produção e circulação da cultura, no reconhecimento do que se entende por patrimônio cultural, se quiser alcançar a amplitude democrática da verdadeira diversidade que pretende representar, deve antes de tudo, fazer a crítica do poder simbólico que se exerce sub-repticiamente sobre as políticas e mecanismos de preservação cultural.

Todos os que até hoje venceram participam do cortejo triunfal, em que os dominadores de hoje espezinham os corpos dos que estão prostrados no chão. $\mathrm{O}$ despojos são o que chamamos de bens culturais (..). Devem sua existência não somente ao esforço dos grandes gênios que os criaram, como à corveia anônima dos seus contemporâneos. Nunca houve um monumento da cultura que não fosse também um monumento da barbárie. E, assim como a cultura não é isenta de barbárie, não o é, tampouco, o processo de transmissão da cultura. (BENJAMIN, 1994, p. 225) 


\subsection{Justiça de Transição}

A justiça de transição é caracterizada pelos esforços em se apurar um passado marcado por graves violações aos direitos humanos. De modo geral, além de englobar julgamentos de criminosos, pode também se referir a planos de reparação, investigação e revelação da verdade histórica por meio de Comissões criadas para esse fim (MEZAROBBA, 2012). Tem o propósito de garantir o Estado Democrático de Direito, de reconhecer as lesões contra os Direitos Humanos das vítimas e permitir a reconciliação com o passado histórico (GENRO \& ABRÃO, 2013). A possibilidade de se escrever uma história alternativa e revisionista representa a refundação de uma cidadania baseada em valores democráticos, ainda que através de uma rememoração dolorosa, que traz à tona um histórico de perseguições políticas, étnicas e religiosas.

As sociedades que passaram por regimes ditatoriais no século $\mathrm{XX}$, durante o período de transição para regimes democráticos, mas principalmente após a consolidação destes últimos, começaram a buscar as verdades históricas e tentar fazer justiça à memória dos mortos e desaparecidos. Em muitos países essa transição foi acompanhada pela tentativa de negociação por uma anistia geral. A América Latina tem um passado marcado pela violência e tradicionalmente, como forma de manter o equilíbrio social, optou pela conciliação através do esquecimento proposital. Sua memória coletiva se baseia na versão oficial da História. A sociedade argentina, entretanto, optou por efetivar a justiça e verdade referente ao período da ditadura militar, julgando penalmente os militares envolvidos em abusos de direitos humanos. O Brasil, ao contrário manteve o padrão da conciliação (SOUZA, 2012). A Lei da Anistia ampla geral e irrestrita L.6.683, de 1979 abrangeu os atos praticados de 02 de setembro de 1961 a 1 de agosto de 1979. Esse prazo foi ampliado posteriormente até 05 de outubro de 1988 pela L. 10.536/2002. O entendimento firmado é de que os destinatários da Lei da Anistia são as pessoas que cometeram crimes 
políticos ou conexos com esses crimes, abrangendo servidores da Administração direta e indireta. Esse sentido do alcance da anistia foi contestado em 2008 pelo Conselho Federal da Ordem dos Advogados do Brasil na ADPF 153, que alegou a não recepção do $\S 1^{\circ}$ do $\operatorname{artigo~} 1^{\circ}$ da Lei da Anistia pela Constituição de 88. O objetivo era evitar que a anistia criminal de natureza política atingisse agentes de estado que praticaram crimes comuns (homicídio, estupro, atentado). Em 2010, o Supremo Tribunal Federal, entretanto, reafirmou o entendimento que prevaleceu até então. Foi confirmada a tese de acordo político conquistado por aqueles que lutaram pela anistia e que só poder ser compreendido em seu contexto histórico. O ministro relator Eros Grau, assim se manifestou em seu voto:

É inadmissível desprezarmos os que lutaram pela anistia como se o tivessem feito, todos, de modo ilegítimo. Como se tivessem sido cúmplices dos outros. Para como que menosprezá-la, diz-se que o acordo que resultou na anistia foi encetado pela elite política. Mas quem haveria de compor esse acordo, em nome dos subversivos? O que se deseja agora, em uma tentativa, mais do que de reescrever, de reconstruir a História?

Desde o fim da ditadura muitos militantes dos Direitos Humanos lutavam pelo direito à memória e à verdade. Houve um longo caminho até a criação de uma política Estatal comprometida com a efetivação desse direito. Um breve resumo da evolução da legislação nos permite compreender que esse processo foi gradual e negociado. L. 9140/ 95: criou no governo de Fernando Henrique Cardoso a Comissão Especial sobre Mortos e Desaparecidos, que reconheceu como mortas as pessoas desaparecidas, detidas pelo poder público sob acusação de atividades políticas no período de 2 de setembro de 1961 a 15 de agosto de 1979, o que permitiu a indenização aos familiares. L. 10536/ 2002: ampliou as hipóteses de aplicação da L. 9140/95 para pessoas assassinadas em manifestações ou nas dependências da Polícia Militar. L.10.559/ 2002: criou a Comissão de Anistia e estabeleceu critérios para o reconhecimento da condição de anistiado político. Todas essas leis permitiram medidas indenizatórias e de reparação às pessoas atingidas por atos arbitrários 
cometidos antes da promulgação da Constituição de 1988. Faltava, porém, o resgate da memória das vítimas e da verdade dos fatos. Apenas com o $3^{\circ}$ Programa Nacional de Direitos Humanos (PNDH-3), sancionado em 21 de dezembro de 2009, foi possível trazer o tema para o debate público. No Programa ficou prevista a criação de uma Comissão Nacional da Verdade (CNV), que foi instituída em 2011 pela Lei n ${ }^{\circ} 12.528$.

A Comissão foi criada com o objetivo investigar e esclarecer as violações de direitos humanos praticadas no período de 1946 a 1988, de modo a efetivar o direito à memória e à verdade histórica e assim promover a reconciliação nacional. No dia 10 de dezembro de 2014, a CNV entregou o relatório com o resultado de seu trabalho, que envolveu pesquisa documental, diligências, depoimentos, oitivas, audiências públicas, fóruns de participação, seminários e intenso debate com a sociedade. ${ }^{20}$

Há quatro princípios básicos para uma justiça de transição: princípio da verdade (verdade histórica trazida pelas Comissões de Verdade e investigações judiciais sobre instituições); princípio da justiça (através da punição dos responsáveis pelas violações de Direitos Humanos); princípio da reparação (compensação das vítimas e familiares); princípio da não repetição: impedir que a certeza da impunidade e o falseamento da verdade induzam à continuidade de práticas de afronta aos Direitos Humanos. (WEICHERT, 2008).

Para a realização desses princípios é imprescindível: (i) a atuação no sentido de revelar a verdade à sociedade e a todos que, direta ou indiretamente foram atingidos pelos métodos do terror; (ii) investigar, julgar e punir os responsáveis pelas violações; (iii) reparar danos; (iv) impedir que os violadores permaneçam em cargos de autoridade. Decorre daí quatro pilares da justiça de transição: verdade e memória, justiça, reparação e reforma institucional. Interessa-nos aqui, o pilar da memória e

${ }^{20}$ http://www.cnv.gov.br/images/pdf/relatorio/volume_1_pagina_959_a 976.pdf. Acesso em 18 de mai. 2015 
verdade, que é marcado pela descontinuidade. Começou com o Decreto $\mathrm{n}^{\circ}$ 5.584/2005, que determinou o envio dos arquivos da Agência Brasileira de Informação (ABIN) ao Arquivo Nacional. Porém, nesse mesmo ano foi promulgada a Lei 11.111, que garantiu o sigilo dos arquivos da ditadura por tempo indeterminado. Só em 2012 entrou em vigor a Lei 12.527/2011, que revogou a L. 11.111/05 e regulou o direito fundamental de acesso à informação previsto no art. $5^{\circ}$, XXXIII, art. $37, \S 3^{\circ}$, II e art. $216 \S 2^{\circ}$ da Constituição Federal de 88 (SANTOS \& SOARES, 2012).

Essa descontinuidade é distintiva de todo o processo de transição democrática no Brasil, eivado pela farsa do acordo político, uma vez que, na realidade, foi orientado por aqueles que "consentiram" na abertura política (MOURA et. al. 2010). As leis de autoanistia, ao forjarem a conciliação pela "superação" de eventos traumáticos e o consenso sobre uma visão histórica imposta de cima para baixo mediante a promessa futura (e não realizada) de uma vida melhor, promoveram a política de esquecimento através do silêncio, e com ela, mais um forma de violência simbólica. Coube à Comissão da Verdade desfazer os apagamentos históricos (como elaborado por Rossi), sistematizando o levantamento documental e de registros diversos.

Se de um lado foi encontrada uma narrativa histórica comprometida com a justificação ideológica para promoção de perseguições políticas (que classificou como terroristas e subversivos aqueles que foram condenados a partir de normas criadas por um regime de exceção), de outro, constatou-se uma memória de resistência (ou na linguagem de Pollak, uma memória subterrânea de sobrevivência oral) através dos relatos de vítimas e testemunhas, que já haviam aparecido nos processos da Comissão Especial sobre Mortos e Desaparecidos Políticos e nos processos da Comissão da Anistia, bem como no livro Direito à memória e à verdade, publicado em 2007. Um dos aspectos da reparação é o reconhecimento do direito de resistência dos perseguidos pelo regime autocrático (GENRO \& ABRÃO, 2013). O resgate desse direito só é possível com a reflexão crítica "sobre o 
conceito de História", como exorta Benjamin. Os vencedores, ao escreverem a história nos deixando como legado documentos falseados, renovam a barbárie do passado através de seus despojos (BENJAMIN, 1994). Nesse sentido, o direito à informação é o instrumento que efetiva o direito à verdade e à memória. A construção da memória coletiva depende do acesso a informações verdadeiras de interesse coletivo sobre o passado. A informação amplia os espectros da liberdade e da realização existencial humana. O art. 19 da Carta de direitos da ONU (1948) dispõe que o direito de receber e transmitir informações e ideias integra a liberdade de opinião e expressão a que todo homem tem direito. A infundada e ilegítima obstrução à informação impulsionada pelo próprio poder público, revela a cumplicidade deste com os abusos cometidos contra os direitos humanos. (GUIMARAENS, 2012). A Lei 12.52 7/2011 foi um passo importante para o reconhecimento de que o Estado brasileiro busca se comprometer com a efetivação dos valores democráticos.

Através do direito à informação, o direito à memória e verdade pode realizar a função social, pedagógica e histórica. A função social se realiza pelo compromisso estatal em revelar a verdade à sociedade. A função pedagógica auxilia na construção de uma consciência coletiva vigilante que pugna pela não-repetição. A função histórica realiza a necessidade de superação de traumas pelo indispensável conhecimento do passado (SANTOS \& SOARES, 2012).

Como vimos, o direito à memória e à verdade está diretamente ligado ao direito fundamental de acesso à informação, expresso no art. $5^{\circ}$, XIV e XXXIII. Além do exposto, considerando que o compromisso com a verdade está normatizado em vários dispositivos do Código de Processo Civil (art. 14, I, art. 17, II, art. 332, art. 339 e art. 415), do Código Penal (art. 342), que o direito à memória e à verdade está expresso no texto da lei que cria a CNV (L. 12.528/11, art. $1^{\circ}$ ) e que nosso Ordenamento Jurídico deve ser compreendido por uma lógica sistêmica; considerando ainda, que a Corte Interamericana de Direitos Humanos firmou entendimento de que as 
vítimas de violações de direito humanos têm o direito de conhecer a verdade sobre os fatos relacionados a essas violações como desdobramento do direito à vida (art. $\left.4^{\circ}, \mathrm{CIDH}\right)$, à informação (art. 7 (4) e 13, CIDH) e ao devido processo legal (art. $\left.8^{\circ}, \mathrm{CIDH}\right)^{21}$ (SAMPAIO \& ALMEIDA, 2009), somando-se a isso os argumentos utilizados na abertura do presente capítulo (com destaque para a cláusula de abertura representada no art. $5^{\circ}, \S 2^{\circ}$ da Constituição de 88), podemos concluir pela fundamentalidade do direito à memória e à verdade.

Em termos benjaminianos, a "salvação histórica" pretendida pelo binômio "direito à memória e à verdade", só é possível com o "anjo da história" que volta seu rosto ao passado. Cabe à memória coletiva, essa espécie de consciência felina, que dirigida ao passado explode o “continuum da história" (BENJAMIN, 1994. p.230), fazer ecoar aos ouvidos de todas as gerações: "para que não se repita, para que nunca mais aconteça"!

[4] Persistência do quadro de graves violações de direitos humanos 9. A CNV, ao examinar o cenário de graves violações de direitos humanos correspondente ao período por ela investigado, pôde constatar que ele persiste nos dias atuais. Embora não ocorra mais em um contexto de repressão política como ocorreu na ditadura militar -, a prática de detenções ilegais e arbitrárias, tortura, execuções, desaparecimentos forçados e mesmo ocultação de cadáveres não é estranha à realidade brasileira contemporânea. Relativamente à atuação dos órgãos de segurança pública, multiplicam-se, por exemplo, as denúncias de tortura, o que levou à recente aprovação da Lei no 12.847/2013, destinada justamente à implementação de medidas para prevenção e combate a esse tipo de crime. É entendimento da CNV que esse quadro resulta em grande parte do fato de que o cometimento de graves violações de direitos humanos verificado no passado não foi adequadamente denunciado, nem seus autores responsabilizados, criando-se as condições para sua perpetuação.

(Relatório da Comissão Nacional da Verdade; 2014, v. 3 .p. $964)^{22}$

\footnotetext{
${ }^{21}$ Cumpre destacar que em 2010 a CIDH notificou o Brasil da decisão do caso Gomes Lund e outros ("Guerriha do Araguaia") vs. Brasil, que entendeu pela incompatibilidade entre a Lei da Anistia brasileira (que veda a pretensão punitiva contra os violadores de Direitos Humanos) e a Convenção Americana de Direitos Humanos (ou Pacto San José da Costa Rica).

${ }^{22}$ http://www.cnv.gov.br/images/pdf/relatorio/volume_3_digital.pdf
} 


\subsection{Preservação dos conteúdos de mídia}

Como já esclarecido, o poder público pode dispor de outros instrumentos de proteção aos bens de valor cultural, além do tombamento e registro. O art. 23, III, IV e art. 24, VII e VIII da Constituição de 88 mencionam como dignos de proteção os bens de valor histórico, artístico, turístico, paisagístico, estético e cultural. Assim, pela redação destes dispositivos, parece que o termo "cultural" não abrange os bens classificados pelas demais categorias de valor (histórico, artístico), mas como o art. $216 \S 5^{\circ}$ tutela o tombamento de documentos e sítios com reminiscências históricas de quilombo, podemos inferir que o patrimônio cultural deve ser compreendido no sentido lato da palavra cultura.

Podemos então considerar que os conteúdos produzidos pela mídia, em seus diferentes formatos, têm valor cultural (documental, histórico, artístico, estético) que enseja sua proteção. Porém, o único conteúdo de comunicação que recebe proteção legal para sua conservação é aquele veiculado pela imprensa tipográfica. Com o intuito de proteger a cultura nacional, foi criado o Depósito Legal, que tem a finalidade de registrar, guardar e divulgar a produção intelectual nacional, preservando-a na Coleção Memória Nacional. O Depósito Legal é disciplinado pela Lei 10.994/ 2004 (refere-se às obras de natureza bibliográfica) e Lei 12.192/ 2010 (para obras musicais) e impõe a obrigação de envio de um exemplar de todas as publicações (apenas obras de prelo) produzidas no país, para a Biblioteca Nacional.

A obrigação de depósito legal existe no Brasil desde o século XIX. Com a vinda da Corte Portuguesa, todas as tipografias portuguesas eram obrigadas a enviar um exemplar para a Real Biblioteca, no Rio de Janeiro, que guardava também a coleção bibliográfica real, símbolo da monarquia, de saber e poder. Com a independência, em 1822, a Real Biblioteca virou Biblioteca Imperial, para a qual a Imprensa Régia enviava suas publicações. 
Já na República, o Depósito Legal foi regulado pelo Decreto 1825, que a Lei 10.994/2004 revogou e substituiu. A criação das bibliotecas nacionais tem intrínseca relação com o surgimento dos Estados Nacionais, pois sempre tiveram a função de guarda da memória nacional e da consolidação de um discurso integrador da identidade nacional (PINTO, 2011). As bibliotecas nacionais são emblematicamente "lugares de memória", no sentido clássico de Nora, como já abordado.

Se toda publicação impressa merece tutela pública por representar a produção intelectual nacional, o conteúdo produzido pelas radiodifusoras não possui o mesmo tratamento. As únicas produções audiovisuais que recebem proteção legal são aquelas produzidas através de fomento ou leis de incentivo, ou ainda, aquelas que receberam do Governo Federal, prêmio em dinheiro. De acordo com o art. $8^{\circ}$ da Lei do Audiovisual (Lei 8685/ 93), todas essas obras devem ter uma cópia enviada à Cinemateca Brasileira. Sobre a conservação de conteúdo das empresas de radiodifusão, o Código Brasileiro de Telecomunicações (Lei 4117/ 1962) assim dispõe:

Art. 71. Toda irradiação será gravada e mantida em arquivo durante as 24 horas subsequentes ao encerramento dos trabalhos diários de emissora.

$\S 1^{\circ}$ As Emissoras de televisão poderão gravar apenas o som dos programas transmitidos.

$\S 2^{\circ}$ As emissoras deverão conservar em seus arquivos os textos dos programas, inclusive noticiosos devidamente autenticados pelos responsáveis, durante 60 (sessenta) dias.

$\S 3^{\circ}$ As gravações dos programas políticos, de debates, entrevistas pronunciamentos da mesma natureza e qualquer irradiação não registrada em texto, deverão ser conservadas em arquivo pelo prazo de 20 (vinte) dias depois de transmitidas, para as concessionárias ou permissionárias até 1 kw e 30 (trinta) dias para as demais.

A "Recomendação sobre a salvaguarda e conservação das imagens em movimento" da Unesco, que data de 1980, prescreve a guarda das produções de "imagens em movimento", em sentido lato, abarcando produções videográficas independentes e produções televisivas. Pela Recomendação, todas essas imagens devem ser consideradas pelos EstadosMembros, como partes de sua "herança imagem em movimento", que 
integram seu patrimônio cultural e por isso devem ser elaboradas políticas públicas adequadas para sua preservação, com integração de agências públicas e privadas objetivando o mesmo fim. Como vimos, as políticas públicas de preservação no Brasil não seguem a recomendação no mesmo alcance dado pela Unesco.

Sobre a necessidade de preservação da produção realizada e distribuída por meios digitais, há a Carta de Preservação Digital da Unesco (2003) e no Brasil, a Carta para a Preservação do Patrimônio Arquivístico Digital do CONARq (Conselho Nacional de Arquivos), porém o assunto ainda não se encontra normatizado. $O$ digital não tem garantia de permanência, uma vez que está subordinado ao desenvolvimento tecnológico, para se manter acessível no presente deve constantemente ser atualizado em conformidade com as novas tecnologias (PINTO, 2011). No Brasil ainda não há depósito de publicações eletrônicas ou quaisquer objetos digitais, conforme recomendação do art. $8^{\circ}$ da Carta Preservação Digital da Unesco:

\footnotetext{
Artigo $8^{\circ}-[$. . . Como elemento chave para a política de preservação nacional, a legislação de arquivos e depósito legal ou voluntário em

bibliotecas, arquivos, museus, e outros repositórios públicos deveria adotar o patrimônio digital. Legislações de direitos autorais e outros direitos relacionados deveriam permitir que os processos de preservação fossem legalmente assumidos por tais instituições.
}

O Marco Civil da Internet (L. 12.965/14) surge para regular o acesso de conteúdo e registro de dados pessoais na internet. Visa promover uma rede digital mais democrática e neutra, a que todos devem ter acesso, buscando assegurar entre outros direitos, a pluralidade, diversidade, finalidade social, liberdade de expressão, comunicação, manifestação do pensamento, informação, conhecimento, participação na vida cultural e assuntos públicos. Essa lei determina que o tráfego das informações na rede não pode ser feito de forma discriminatória por quem oferece o serviço de transmissão de dados. Além disso, para impedir a censura de cunho 
econômico ou ideológico, fica estabelecido que o provedor de aplicações só poderá retirar conteúdo do ar mediante ordem judicial (à exceção de casos graves de violação à intimidade). A decisão de retirada cabe a um juiz de direito, que irá avaliar a ilegalidade do conteúdo e ponderar entre o interesse individual e os interesses da coletividade. Ainda assim, vemos que o dever de isonomia no tratamento dos dados, refere-se aos provedores de acesso, não aos provedores de aplicativos.

Art. $9^{0} \mathrm{O}$ responsável pela transmissão, comutação ou roteamento tem o dever de tratar de forma isonômica quaisquer pacotes de dados, sem distinção por conteúdo, origem e destino, serviço, terminal ou aplicação.

§ $1^{\underline{0}} \mathrm{~A}$ discriminação ou degradação do tráfego será regulamentada nos termos das atribuições privativas do Presidente da República previstas no inciso IV do art. 84 da Constituição Federal, para a fiel execução desta Lei, ouvidos o Comitê Gestor da Internet e a Agência Nacional de Telecomunicações, e somente poderá decorrer de:

I - requisitos técnicos indispensáveis à prestação adequada dos serviços e aplicações; e

II - priorização de serviços de emergência.

$\S 2^{\circ} \mathrm{Na}$ hipótese de discriminação ou degradação do tráfego prevista no $\S 1^{\underline{o}}$, o responsável mencionado no caput deve:

I - abster-se de causar dano aos usuários, na forma do art. 927

da Lei no 10.406 , de 10 de janeiro de 2002 - Código Civil;

II - agir com proporcionalidade, transparência e isonomia;

III - informar previamente de modo transparente, claro e suficientemente descritivo aos seus usuários sobre as práticas de gerenciamento e mitigação de tráfego adotadas, inclusive as relacionadas à segurança da rede; e

IV - oferecer serviços em condições comerciais não discriminatórias e abster-se de praticar condutas anticoncorrenciais.

$\S 3^{0} \mathrm{Na}$ provisão de conexão à internet, onerosa ou gratuita, bem como na transmissão, comutação ou roteamento, é vedado bloquear, monitorar, filtrar ou analisar o conteúdo dos pacotes de dados, respeitado o disposto neste artigo.

Quando pensamos na circulação e acesso a conteúdos por meio de aplicativos, fica mais difícil verificar a isonomia. Muitas agências de mídia e empresas de comunicação, através do chamado Marketing Digital (ou Marketing de Conteúdo) conseguem “esquentar” seu conteúdo melhorando seu posicionamento no ranking da lista trazida pelos sites buscadores, ou 
dando destaque nas redes sociais. Os grandes grupos econômicos, além de utilizarem links patrocinados (por exemplo, através de serviços como o Google Adwords), contratam serviços de profissionais de mídia altamente especializados em "viralizar" ou "bombar" seus conteúdos, como se diz na linguagem corrente. Há sofisticados mecanismos de marketing digital, que através do planejamento de palavras-chaves e combinação de filtros, entre outras ferramentas, são capazes de gerenciar e prever o tráfego de informações. Esse conhecimento não está acessível a qualquer um. Constitui um saber valorizado e muito fechado em nichos especializados. ${ }^{23}$ Com isso não se está querendo dizer que a internet não é um ambiente democrático. Por certo que é, e a qualidade do conteúdo disponibilizado supera muitas vezes as melhores técnicas de marketing disponíveis ao domínio econômico. Não raro, ocorrem fenômenos imprevisíveis e inexplicáveis, que escapam a todas as tentativas de racionalização de quem gerencia a circulação digital. Porém, é preciso destacar que o Marco Civil, apesar de defender a neutralidade da rede, não impede que as manipulações aconteçam no meio digital e interfiram na circulação democrática de informações.

Em recente artigo no jornal "Folha de São Paulo",24 Ronaldo Lemos informou que importantes jornais do mundo anunciaram que irão publicar seus conteúdos diretamente no Facebook e lembrou que dias antes, a própria rede social divulgou a conclusão de um estudo chamado a "Exposição a Notícias e Opiniões Ideologicamente Diversas no Facebook", que revelou que a timeline de cada usuário mostra mais notícias que estão de acordo com seu perfil ideológico, reduzindo as possibilidades de visualização de conteúdo que contrasta com suas opiniões, ou com aquilo que majoritariamente circula em seu perfil. Isso se deve aos arranjos

\footnotetext{
23 Informações verbais de publicitários de mídias digitais em entrevistas concedidas por: TRINDADE, Karlili. Depoimento (19 de mai. 2015). Entrevistador: Ingrid Borges de Lemos. Rio de Janeiro. 1 arquivo .mp3 (30 min); LIMA, Luis Cláudio da Silva. Depoimento (20 de mai. 2015). Entrevistador: Ingrid Borges de Lemos. Rio de Janeiro. 1 arquivo .mp3 (40 min)

${ }^{24}$ Disponível em: http://www1.folha.uol.com.br/colunas/ronaldolemos/2015/05/1629738precisamos-falar-dos-algoritmos.shtml\#. Acesso em 19 de mai. 2015.
} 
algorítmicos formulados pelo próprio site. As ambições de crescimento do Facebook induzem que o site parece pretender se tornar "a própria internet". Em dezembro de 2014 a revista "Time",25 revelou que o site pretende disputar com o Youtube o mercado de visualização de vídeos, promovendo o recurso que permite aos seus usuários "subirem vídeos" diretamente de sua plataforma, sem precisar colocá-lo no Youtube, a principal referência de conteúdo audiovisual na internet. A principal diferença entre os dois aplicativos, é que o Youtube é referência como buscador de vídeos, enquanto o Facebook é o grande "viralizador" das instantaneidades. Por tudo isso, percebemos que há um conjunto de regras e determinações algorítmicas que combinadas promovem conteúdos de maneira desigual. As grandes empresas de mídia possuem métricas de visualização de conteúdo que não estão acessíveis a todos.

Podemos concluir, portanto, que, ainda que um conteúdo esteja "guardado" na rede e não possa ser excluído por terceiros, não necessariamente irá aparecer no resultado de uma busca, por exemplo, pois isso depende das metodologias de rankeamento utilizadas pelos aplicativos de busca, cujos mecanismos de eficiência são largamente dominados por quem detém o poder econômico. Além disso, as redes sociais, que funcionam como grandes difusoras de conteúdo, não têm a mesma eficiência de recuperação do que já circulou, como nos sites de busca. $\mathrm{Na}$ prática, um conteúdo existente, mas não localizado, não está guardado, mas perdido.

O Marco Civil, apesar de impedir que um conteúdo seja excluído da rede por terceiros, a não ser em caráter excepcional, não regula a guarda da produção digital. Esta ainda depende de uma política de preservação. Um conteúdo digital, independentemente do seu valor intelectual, histórico, político e/ ou cultural, pode ser apagado por seu responsável direto, sem passar por um juízo de ponderação de sua relevância coletiva. Ainda assim, convém assinalar, mais do que qualquer outro meio de comunicação, a

\footnotetext{
${ }^{25}$ Disponível em: http://time.com/3634472/fb-vs-youtube-video/. Acesso em 19 de mai. 2015.
} 
internet mantém sua vocação democrática. É um poderoso instrumento para dar voz aos discursos minoritários, ainda que às vezes sejam encontrados apenas na "página 2", ainda que seja necessária paciência para se encontrar as palavras-chave que abrem as portas de um universo marginalizado. Por isso a necessidade de se manter um olhar crítico em vigilância permanente.

É preciso considerar ainda, que a inexistência de políticas públicas para preservação de conteúdo midiático não impede que as grandes empresas de comunicação tenham seus Centros de Documentação. Com efeito, a maioria os têm. Como vimos em Huyssen, o passado é um negócio para essas empresas. Os conteúdos do passado, além de diretamente se prestarem à venda externa, através de uma agência comercial, também servem como incremento para as produções atuais, como por exemplo, para ilustrar séries históricas, datas comemorativas ou para serem usadas como efeito comparativo de eventos similares.

Esses Centros de Documentação continuam sendo lugares de memória, com narrativas majoritárias sobre o passado, sobre o presente e projetadas para o futuro. De um lado guardam suas produções audiovisuais e impressas, que qualquer um pode ter acesso mediante o devido pagamento. De outro, se pensarmos nas produções jornalísticas, todos os jornais impressos são guardados na Biblioteca Nacional e fazem parte da Coleção Memória Nacional. Pensemos ainda que, tudo o que é impresso no jornal de hoje, foi veiculado pelos telejornais no dia anterior. Nesse cenário, as memórias das narrativas marginais, contra-discursos produzidos com auxílio das novas tecnologias de comunicação, como os celulares, que criam vídeos independentes, amiúde frutos de iniciativas individuais, continuam vocacionadas a permanecer como memórias subterrâneas, no sentido de Pollak. Conseguem emergir nos contextos de tensão e ruptura e apenas são reconhecidas pelo Estado como memória nacional, quando suas narrativas são mediadas por intelectuais, que interpretam seus discursos e materializam-nos no prelo, ou pelos autores saídos diretamente das vozes marginais, que acabam tornando-se seus representantes. 
O século XXI assiste a formação da chamada literatura marginal. Trata-se de narrativas de autores das periferias brasileiras que tem em Ferréz (Reginaldo Ferreira da Silva) sua principal referência. Essas narrativas se caracterizam por um posicionamento político que denuncia os mecanismos de manutenção da margem do saber e poder a partir de experiências próprias de seus autores, promovendo rupturas no discurso totalizante da identidade nacional e das versões oficiais dos fatos e da história que procuram esmaecer os conflitos internos. Na literatura periférica a autoridade narrativa se potencializa na afirmação das tensões, isto é, na tomada de consciência contra a farsa da liberdade e dos direitos iguais, a partir da perspectiva de quem vive a realidade disjuntiva do que se quer fazer acreditar e do que verdadeiramente é. A principal referência da narrativa marginal é a rua, o "não-lugar" (AUGÉ, 2004)². Território onde todos estão de passagem porque é o lado de fora, o lugar do "desacolhimento" e por isso, espaço identificado com o marginal. A partir da tomada de consciência, a condição marginal territorializada passa a ser a própria identidade (PATROCÍNIO, 2003). O "não-lugar" (originalmente desprovido de valor simbólico) passa a ser ressignificado como identidade do que se quis invisibilizar. "Me tomaram tudo, menos a rua", diz a legenda de uma foto de Ferréz (2000). O autor se reconhece no vínculo com a rua, mas ao mesmo tempo se destaca de seu meio social. Como escritor reconhecido, passa a ser aquele que "tem a palavra". Ganha visibilidade no lugar onde todos são invisíveis. Curiosamente, esse escritor é identificado como "fora do lugar", é a margem da margem (PEREIRA, 2013).

Dá-se então um fenômeno aparentemente paradoxal: os escritores constroem sua identidade pelo pertencimento àquele espaço, pelo conhecimento particular que têm dele, mas declaram sua diferença em relação à comunidade que afetam representar (em todas as acepções do termo) (PEREIRA, 2013. p.191).

\footnotetext{
${ }^{26} \mathrm{O}$ antropólogo Marc Augé utiliza o termo para se referir a espaços de passagem, nos quais não são reconhecidas relações identitárias contínuas. Seria o oposto a "lugar de memória. Por seu caráter transitório, não poderia ser definido nem como espaço histórico, nem identitário nem relacional". O não-lugar nunca pode existir como forma pura, pois é eternamente reconstituído por novas dinâmicas. Ele seria o não simbólico em oposição ao lugar antropológico simbolizado. (AUGÉ, Marc, 2004. p. 73-77)
} 
Essa função do intelectual e também do escritor marginal como representante das vozes silenciadas, é questionada por Spivak (2014). Quando a autora analisa a postura do intelectual pós-colonial e o significado de representação, assinala que qualquer ato de resistência feito em nome do subalterno (subalterno aqui não é qualquer marginalizado, mas aquele que não pode se fazer ouvir. Além disso, entende-se por subalternidade uma infinidade de heterogeneidades) reproduz a lógica opressiva imperialista da narrativa unívoca. Não oferece ao subalterno a possibilidade de falar diretamente. $\mathrm{O}$ discurso implica um espaço dialógico entre aquele que fala e aquele que houve, mas ao subalterno esse espaço sempre é negado, nunca pode reivindicar em nome próprio, mas sempre através de mediações de representantes intelectualizados. Com isso, Spivak não está rejeitando o papel dos intelectuais na denúncia dos mecanismos de opressão, mas sim o que chama de "violência epistêmica" (2014, p.60) imperialista, que não se limita a tornar visíveis esses mecanismos, mas avoca e interpreta a vontade do subalterno, uma vez que este não existe irrepresentável. O papel do intelectual seria então, não o de representar o subalterno, mas de vocalizálo, "presentá-lo" em espaços que possa ser ouvido falando em nome próprio.

É nesse sentido que o fenômeno das manifestações de junho de 2013 se mostra muito emblemático, ou seja, pela rejeição das vozes intermediadoras dos representantes. Aqueles que foram às ruas, se tonaram presentes em suas próprias vozes. Os vídeos gravados por celulares e que inundaram as redes sociais, eram expressões não mediadas por nenhum discurso intelectual ou midiático. Daí a grande riqueza dessa memória produzida. Pela primeira vez a heterogeneidade multitudinária pôde se fazer ouvir sem admitir ser cooptada por um sentido totalizante. Porém é uma memória precarizada, que não goza de nenhuma garantia de que estará disponível no futuro.

Os suportes da memória coletiva são muito variados e, hoje, não há mais hierarquia rígida entre as diversas formas de registro: a 
chancela oficial não é mais o critério da fidedignidade ou da importância de uma lembrança. A multiplicidade de elementos e registros do patrimônio não permite reduzi-los a um denominador comum que sirva de critério de definição do que é preservável. Por isso, é exatamente na escolha e aplicação do critério de identificação que a dimensão política-ideológica aparece de forma mais contundente, pois a "possibilidade de construção fechada de uma versão unívoca do passado repousa no poder de decidir sobre o que será ou não preservado enquanto registro à disposição da posteridade (SILVA, 1992, p.19 apud DANTAS, 2008, p. 100) 


\title{
3. NARRATIVAS MIDIÁTICAS PRODUZINDO MEMÓRIA SOBRE AS MANIFESTAÇÕES: TERRITÓRIOS EM DISPUTA
}

\author{
Pela janela do quarto/ Pela janela do carro/ Pela tela, pela \\ janela/ Quem é ela?/ Quem é ela?/ Eu vejo tudo enquadrado/ \\ Remoto controle (...) \\ (Esquadros. Composição de Adriana Calcanhoto)
}

\subsection{Junho de 2013}

Em junho de 2013 ocorreram no Brasil os eventos batizados de "manifestações", um conjunto de mobilizações populares que levaram milhares de pessoas às ruas das principais capitais do país, como não acontecia havia mais de vinte anos. Até então, movimentos semelhantes no sentido de ampla capacidade de participação popular foram constatados em 1992, pelo impeachment do ex-presidente Collor, em 1984, pelo fim do regime militar com o "Movimento Diretas Já", e em 1968 com a "Passeata dos Cem Mil, ocorrida no Rio de Janeiro, contra a ditadura.

No contexto das manifestações, o país vivia os preparativos para os megaeventos: a Copa das Confederações, marcada para junho de 2013, a Copa do Mundo, marcada para um ano depois e as Olimpíadas de 2016 (estas últimas a se realizarem na cidade do Rio de Janeiro). Os elevados gastos com a construção de estádios esportivos e todos os recursos públicos aportados nos megaempreendimentos destoavam da qualidade de serviços básicos oferecidos à população saúde, segurança pública, transportes. Aliado a isso, havia o aumento do custo de vida com a elevação da inflação, notícias de corrupção, votação da PEC 37, cujo texto, se aprovado, retiraria o poder de investigação do Ministério Público (GOHN, 2014). Estava configurado um panorama de crise que começou a emergir com o esgotamento do modelo de crescimento econômico alavancado pelas exportações de commodities às economias capitalistas mais desenvolvidas e em franca expansão, como a China, mas que entraram em declínio com a crise financeira de 2008. As política sociais de transferência de renda retiraram mais de trinta milhões de brasileiros da pobreza, os programas de 
concessão de crédito estimularam o consumo, o país se tornou o $6^{\circ}$ maior PIB do mundo com grande influência da América Latina e no BRICS, mas nada desse crescimento se reverteu para investimento em infraestrutura para a população. Com a crise econômica mundial, sobreveio a desaceleração de nossa economia, agravada pelo endividamento estimulado pela febre consumista e pela elevação da taxa de juros bancários. Junto com a perda do poder aquisitivo havia a fome do mercado imobiliário, que viu nas cidades sediadoras dos megaeventos, grandes oportunidades para o investimento especulativo (NOGUEIRA, 2013).

Os megaeventos promovem um processo de mercantilização das cidades. Estas, transformadas em empresas de capital aberto, disputam entre si investimentos de megaempreendedores de um mercado global. As cidades neoliberais se abrem ao cartel da FIFA e do COI (Comitê Olímpico Internacional), articulando isenção fiscal com o capital de corporações internacionais e nacionais. Com o discurso político de que estratégias desenvolvimentistas voltadas ao turismo salvaguardam as cidades da decadência provocada pela concentração populacional, pelo aumento da violência, do desemprego, da crise econômica, da deterioração ambiental, cultural, da precariedade de infraestrutura, da mobilidade urbana e das desigualdades sociais, governantes oferecem áreas valorizadas do espaço urbano ao monopólio privado para exploração de serviços (VAINER, 2013; SANTOS \& PEIXOTO, 2013). Na realidade ocorre o aprofundamento de todas as contradições que a retórica política dizia pretender evitar. Assistimos a vorazes processos de gentrificação, com higienização social, limpeza de áreas nobre e remoções das camadas mais pobres. As cidadesempresa se transformam em grandes centros de consumo, com estruturas para o entretenimento, apenas disponíveis àqueles de maior poder aquisitivo. O "empreendedorismo urbano" e "concorrência interurbana" (HARVEY, 2005, p. 178) aumentam a distância entre riqueza e renda trazendo como consequência o depauperamento das condições de vida urbana. O marketing imagético singulariza a cidade como produto, para 
torná-la mais atraente. A construção dessa imagem forja uma identidade de lugar, que se torna capital simbólico para venda de pacotes turísticos. Essa identidade também oferece à população local a noção de pertencimento à cidade, escamoteando a real degradação urbana. A imagem de sucesso representa uma vitória política. "Mesmo se falta o pão, o circo prospera. $\mathrm{O}$ triunfo da imagem sobre a substância é total" (HARVEY, 2005. p.185).

As adequações da cidade ao capitalismo neoliberal limitam o direito à cidade ${ }^{27}$. Para Harvey (2013), mais do que um direito de acesso à cidade que já existe, trata-se do direito que as pessoas têm de transformar a cidade em conformidade com seus desejos e necessidades. Porém, lembrando $\operatorname{Marx}^{28}$, o autor questiona como isso seria possível, se o poder de decisão está naquele que detém a força capaz de impor sua vontade. A resposta ele encontra em Lefebvre ${ }^{29}$ : por meio da força mobilizadora das lutas sociais e políticas, que precisam ter o dever e a coragem de realizar o confronto. Apenas a reunião das forças da coletividade que se descarrega em ação política, efetiva o direito à cidade, mas isso exige solidariedade social, o que por sua vez, demanda a criação de espaços urbanos dialógicos de participação comum democrática (HARVEY, 2013). Aqui se opera uma dialética: esses espaços devem conduzir à catalisação de forças de mobilização política, essas forças devem ter a competência de pressionar a abertura desses espaços. "O direito à cidade não é um presente. Ele tem de ser tomado pelo movimento político" (HARVEY, 2013 p.34).

A cidade transformada em patrimônio, dotada de valor simbólico e alvo do mercado imobiliário especulativo, aumenta a distância entre centro e periferia. A população desfavorecida é afastada de seu local de trabalho. A condição de mobilidade urbana representa enorme dificuldade para os excluídos da cidade-empreendimento. Por isso, dentro de todo esse

\footnotetext{
${ }^{27}$ Conceito elaborado por Henri Lefebvre: "O direito à cidade não pode ser concebido como um simples direito de visita ou de retorno às cidades tradicionais. Só pode ser formulado como direito à vida urbana, transformada, renovada". (O Direito à Cidade. 5. ed. São Paulo: Centauro Editora, 2008, p.139)

${ }^{28}$ MARX, Karl. O capital (São Paulo, Boitempo, 2013), Livro I, p. 309

${ }^{29}$ LEFEB VRE, Henri. A revolução urbana (Belo Horizonte, Editora UFMG, 1999).
} 
panorama, no Brasil, o estopim para as mobilizações de junho de 2013 foi o aumento de 0,20 centavos nas passagens de ônibus urbanos.

Os primeiros protestos ocorreram em Porto Alegre, no dia 27 de março de 2013. Depois de duas semanas uma decisão judicial suspendeu o aumento. Em maio foi a vez de Goiânia e Natal reagirem aos aumentos. No dia 02 de junho o prefeito de Natal também anuncia a redução das passagens. No dia seguinte, o Movimento Passe Livre (MPL) coordena a primeira mobilização contra o aumento das passagens em São Paulo. No mesmo dia, um grupo de manifestantes se reúne em frente à Assembléia Legislativa do Rio de Janeiro (Alerj) e ocupa a avenida Rio Branco pedindo o fim do aumento das passagens. Nos dias que se seguem, os protestos continuam em São Paulo. Em 07 e 08 de junho, é anunciada, respectivamente, a revogação do aumento pelos prefeitos de Manaus e Vitória. No dia 11 de junho, em São Paulo começam episódios de violência policial, incêndios dos manifestantes para interromper o trânsito, depredações de agências bancárias, lojas e ônibus. O prefeito Fernando Haddad e o governador Geraldo Alckmin assistiram as notícias à distância, em Paris e se posicionaram contra a atuação dos manifestantes. O dia 13, data marcada para o quarto protesto do Movimento Passe Livre em São Paulo, foi o grande momento de inflexão no derrame das manifestações. A mídia exigiu ações mais intensas e eficazes do poder público, manifestantes foram comparados a organização criminosa. A força policial usou seu poder sangrento para intimidar os manifestantes: uso de bombas de gás lacrimogêneo, tiros de borracha, ataques com cassetetes, detenções arbitrárias. Ninguém foi poupado: pedestres, passageiros de ônibus, jornalistas, moradores de rua. Uma repórter da "Folha de São Paulo" teve um olho atingido por uma bala de borracha, e acusou a polícia de ter disparado em sua direção intencionalmente. No dia seguinte a imagem de seu rosto coberto de sangue circulou em várias mídias. O mesmo ocorreu com um fotógrafo, que perdeu a visão do olho atingido. Imagens da violência policial invadiram todas as redes sociais, transmitidas diretamente 
através de vídeos de celular gravados por participantes dos protestos. A mídia não conseguia mais ignorar a repressão desmedida da força policial e mudou seu enquadramento. No dia 15 acontece a abertura da Copa das Confederações e a presidenta Dilma é vaiada. No dia 17, multidões de manifestantes ocupam, num gesto de forte estética simbólica, a Esplanada dos Ministérios. Os protestos continuam nos dias que se seguem e atingem o ponto máximo no dia 20 de junho, quando mais de um milhão de pessoas tomam as ruas em mais de 300 cidades do Brasil. Esse protesto é marcado por novas reivindicações, pela presença de black blocs, pela brutal hostilidade aos partidarismos, muitos confrontos violentos com a polícia e depredações. A partir de então, se verifica o começo do esvaziamento das manifestações, com a retirada de apoio popular. No dia seguinte a presidenta faz um pronunciamento prometendo um pacto com governadores e prefeitos visando melhorar os serviços públicos, e sugere que $100 \%$ dos royalties do petróleo devem ser investidos em educação. Nesse mesmo dia o MPL comunica que não fará mais convocações para as manifestações por discordar do caráter autoritário que estas estavam assumindo. No dia 25 a PEC 37 é rejeitada. No dia 30, cerca de 5 mil pessoas se dirigem ao estádio Maracanã, onde está ocorrendo a partida final da Copa das Confederações, para protestar contra a concessão do estádio à iniciativa privada e contra projetos de reformulação urbana em torno da região, que previam a demolição do parque aquático Júlio Delamare para construção de um estacionamento. É feito um cerco policial para impedir que manifestantes sem ingresso cheguem ao local. Um novo protesto no final tarde é debelado pela ação violenta da polícia (BORBA et al, 2014).

Em linhas gerais, os protestos tiveram três grandes momentos: a criminalização dos atos pela mídia; a ampla adesão popular após a violência da polícia; a conquista da redução do aumento das passagens e mudança do viés espontâneo das manifestações, com tentativas de captura de pautas, reivindicações alinhadas com uma direita reacionária, radicalização da violência. 
Além da importância que as novas e velhas redes de mídia tiveram no processo das manifestações de junho, cumpre ressaltar, embora não seja o caso de explorar os meandros de sua participação, o papel do MPL, do coletivo Anonymous e dos Black Blocs, que mereceriam uma abordagem mais acurada que não pode ser alcançada pelo objetivo deste trabalho. $\mathrm{O}$ MPL foi importante por ter iniciado as convocações contra os aumentos das passagens, o Anonymous por seu intenso ativismo digital na segunda fase do processo e os Black Blocs por terem mudado a cara dos protestos e despertado intensas discussões sobre sua função e legitimidade: ora criminalizados por um viés mais conservador que interpreta sua atuação como vandalismo gratuito, ora considerados heróis por defenderem os manifestantes da brutalidade policial (GOHN, 2014).

As manifestações de junho de 2013 foram alinhadas com as revoltas e protestos de multidões ocorridos anteriormente em outros países, nomeadamente a Primavera Árabe, o Occupy Wall Street (EUA), o 15-M (Espanha) e a Revolta das Panelas (Islândia). Castells assinalou os pontos de identificação entre esses eventos: a "autocomunicação de massa" (2013, p.16) por meio das redes digitais; conexões múltiplas; forte impacto emocional sobre os indivíduos; ocupação de espaços simbólicos; o espaço urbano como base de ocupação; estrutura descentralizada; viés local e global; alto poder exercido pelas imagens, com destaque para os vídeos e suas plataformas de circulação; a viralização e horizontalidade de sua difusão; afirmação da "cultura da autonomia" (CASTELLS, 2013, p.170); reivindicações plurais (raramente têm conteúdo programático); desobediência civil que se inicia pacificamente mas depois é reprimida com brutalidade, cuja intensidade variável, dá o tom da violência.

Para além desse caráter geral apontado por Castells, junho de 2013 é um evento múltiplo também na capacidade de gerar interpretações. Em poucos meses desde seu início, já havia várias publicações, inclusive com a participação de intelectuais internacionais, avaliando o evento e seus desdobramentos (as manifestações continuaram em algumas cidades, mas 
assumindo matizes próprios. Especialmente no Rio de Janeiro se mostraram bem insistentes, denunciando a violência física e simbólica que sequestrou a cidade para atender aos interesses das grandes corporações e de políticos envolvidos nos empreendimentos dos megaeventos). Foram e continuam sendo divulgadas pesquisas e produções bibliográficas que muito auxiliaram na elaboração do presente trabalho. Por elas constata-se que o significado das manifestações continua sendo disputado, mas o recorte aqui se prende às produções de sentido efetuadas pelas narrativas midiáticas (tradicionais e alternativas) no período de junho de 2013.

\subsection{Narrativas midiáticas}

Quando aconteceu a Primavera Árabe ${ }^{30}$, a mídia tradicional mundial logo lhe expressou seu apoiou, apontando o potencial libertador da internet pela possibilidade de realização dos direitos de liberdade de expressão e de imprensa. A internet havia criado um modelo para a mídia, que projetava fatos inéditos numa grande diversidade de perspectivas. Em vários lugares do globo começaram a eclodir movimentos semelhantes. Porém, quando surgiu o movimento Occupy Wall Street ${ }^{31}$, que dentre suas múltiplas pautas expôs o caráter manipulador de uma mídia que, associada aos interesses dos $1 \%$ mais ricos do mundo, filtra informações e privilegia seu próprio conteúdo noticioso, os meios de comunicação tradicionais trataram de começar um narrativa de deslegitimação do movimento, traçando grandes distâncias em relação aos protestos da população árabe (SOLHA, 2013) ${ }^{32}$.

\footnotetext{
${ }^{30}$ Conjunto de protestos ocorridos entre final do ano de 2010-2011, em que multidões mobilizadas através das redes sociais ocuparam as praças da Tunísia, Egito e outros países árabes, para pedir a derrubada de ditaduras.

${ }^{31}$ Occupy Wall Street (OWS) é um movimento inspirado pela Primavera Árabe, que começou no dia 17 de setembro de 2011 ocupando a Liberty Square, centro financeiro de Manhattam, e depois se espalhou por centenas de cidades norte-americanas. Seu principal objetivo é lutar contra as desigualdades sociais provocadas pela ditadura econômica imposta pelo $1 \%$ mais rico do mundo. Dentre seus slogans está: "Nós somos os 99\%". (Fonte: http://occupywallst.org/)

${ }^{32}$ Texto originalmente apresentado, sob a forma de conferência, no I Colóquio Internacional Arrogância, UFMG/Université de Bordeaux/Grupo Cosmopolita/CNRS, em setembro de 2013.

Disponível em: http://observatoriodaimprensa.com.br/jornal-dedebates/_ed769 mediae as manifestacoes_de_junho_controle_e disputa Acesso em 24 mai/ 2015.
} 
Anne Applebaum (2011), premiada jornalista norte-americana, assim se referiu na coluna Opinião do jornal Washington $\operatorname{Post}^{33}$ :

Em Nova York os manifestantes cantaram "essa é a cara da democracia", mas na verdade essa não é a cara da democracia. É a cara da liberdade de expressão. (...) Diferentemente dos egípcios na praça Tahrir, com quem os manifestantes de Londres e Nova York se comparam de maneira aberta (e ridícula), nós temos instituições democráticas no mundo ocidental. Elas são planejadas para refletir, pelo menos de modo grosseiro, o desejo de transformação política dentro de uma dada nação. Porém, não podem resolver o desejo de transformação política global (...) —, a globalização claramente passou a minar a legitimidade das democracias ocidentais (...)

Os ativistas "globais", se não forem cuidadosos, acelerarão seu declínio. Manifestantes em Londres gritam "Precisamos de um processo!" Bem, eles já têm um processo: chama-se sistema político britânico. E, se não souberem usá-lo, simplesmente o enfraquecerão.

Ao afirmar que os manifestantes do Occupy têm liberdade de expressão e instituições democráticas, Applebaum invisibiliza as críticas dirigidas à mídia e a todo o sistema que ela ajuda a sustentar. Como bem analisado por Zizek (2012), a jornalista não apenas esgotou o conceito de democracia em sua expressão formal, através de suas instituições (da qual a imprensa tradicional faz parte), como culpabilizou os manifestantes pelo seu enfraquecimento e, por conseguinte, pelo estiolamento da própria democracia. Em outros termos, as manifestações na realidade teriam um viés anti-democrático. Os gritos por democracia real, fora dos esquadros formais que Zizek chamou de "moldura liberal" (2012, p. 22), são silenciados com a clara finalidade de desqualificar a crítica às estruturas que garantem o funcionamento do sistema em seus próprios termos. No início de seu artigo, Applebaum afirma que a "democracia é baseada na regra da lei; funciona somente dentro das fronteiras nítidas entre pessoas que se sentem parte de uma nação".

Tal raciocínio se emprega à prestidigitação de não fazer ver que os fluxos econômicos globais que derrubaram os muros da força de trabalho

\footnotetext{
${ }^{33}$ Disponível em: http://www.washingtonpost.com/opinions/what-the-occupy-protests-tell-usabout-the-limits-of-democracy/2011/10/17/gIQAay5YsL story.html Acesso em 24 mai/ 2015.
} 
industrial e do consumo local, deram ensejo ao surgimento de uma mão de obra que trabalha por cooperação e em redes de comunicação, estendendo os limites da solidariedade, antes circunscritos ao Estado-nação, para todo o globo. A circulação de riquezas veio acompanhada da circulação de valores, com imbricamentos políticos, econômicos e culturais, impactando na vida em sociedade, o que Negri e Hardt chamaram de "produção biopolítica" (2001, p.41). O biopoder do Império ${ }^{34}$, destinado a regular a sociedade em escala global, cria as condições de emergência da multidão, dotada de potência motriz contra a voracidade ilimitada do neoliberalismo. Essa multidão não se caracteriza por uma identidade-nação (não é povo), nem pela indistinção definidora das massas. Ela deseja produzir e distribuir o comum (the common) numa imensa rede colaborativa mundial. Sua força democrática se afirma na própria pluralidade multitudinária das pautas e dos insurgentes (NEGRI \& HARDT, 2014). Daí a completa (e proposital) contramão da perspectiva de Applebaum, que representa o tom que a narrativa da imprensa tradicional irá assumir a partir de então, para abordar os fenômenos das manifestações .

A moeda comum que circula hoje em dia em tantos movimentos e lutas de libertação através do mundo - no nível local, no regional e no global - é o desejo de democracia. Nem é preciso lembrar que reivindicar a democracia global não assegura sua concretização, mas não devemos subestimar o poder que essas demandas podem ter. (HARDT \& NEGRI, 2014, p. 15).

No Brasil, a abordagem midiática tradicional não foi diferente. Logo de início houve a indisfarçável tentativa de denegrir e criminalizar as manifestações. Conforme o recrudescimento da violência policial, inclusive tendo jornalistas como vítimas, e a ampla circulação de vídeos produzidos por manifestantes que contrastavam com as versões da imprensa formal, o

\footnotetext{
34 “Deve-se salientar que 'Império' é usado aqui não como metáfora (...) O conceito de Império caracteriza-se fundamentalmente pela ausência de fronteiras: o poder exercido pelo Império não tem limites. Antes e acima de tudo, portanto, o conceito de Império postula um regime que efetivamente abrange a totalidade do espaço, ou que de fato governa todo o mundo "civilizado". Em segundo lugar, apresenta-se (...) como uma ordem que na realidade suspende a história e dessa forma determina, pela eternidade, o estado de coisas existente" (HARDT \& NEGRI, 2001, p.14).
} 
tom crítico negativo arrefeceu, mas deu lugar a uma versão mais dissimulada, com sequestro de pautas, que apontava como principal motivo das manifestações o descontentamento com o governo do PT e a corrupção, e criou uma narrativa de polarização entre protestos legítimos, realizados pelos chamados "manifestantes pacíficos" (que depois viraram somente "manifestantes") e os ilegítimos, dos quais apenas participavam os chamados "vândalos".

A postura ambivalente e por vezes tendenciosa dos meios tradicionais de comunicação levou à uma disputa narrativa com os usuários de tecnologias digitais. Organizações com páginas oficiais passaram a convocar as redes sociais (Twitter, Facebook, Youtube) para as ruas. Houve aumento dos compartilhamentos tanto de matérias digitais das mídias tradicionais online, quanto de conteúdos produzidos livremente por sites próprios, perfis oficiais e vídeos gravados por celular pelos que presenciaram os protestos, seja das ruas ou das janelas. Estes vídeos, postados quase instantaneamente ou transmitidos ao vivo (streaming) foram essenciais como elemento galvanizador das multidões (SÔLHA, 2013)

Para efeito de melhor compreensão, serão analisadas separadamente as construções narrativas na mídia tradicional e nas redes sociais.

\subsubsection{As manifestações nas redes sociais}

A empresa Interagentes, especializada em monitoramento de comunicação digital, como circulação de redes, divulgou em seu site um levantamento chamado "Cartografia de Espaços Híbridos: As manifestações de junho de 2013" 35. O documento revela a análise da circulação de conteúdos compartilhados a partir de perfis do Facebook, no período compreendido entre 05 a 21 de junho de 2013. A metodologia consistiu em identificar o que chamou de "Autoridade" (perfil que tem postagens muito compartilhadas) e "HUB" (que funciona como replicador do que outros

35 Disponível em http://interagentes.net/?p=62 Acesso em 25 mai/2015 
perfis compartilham). ${ }^{36}$ De acordo com as análises, os eventos criados no Facebook para divulgação das manifestações, foram construídos de forma heterogênea e capilar, funcionando de modo colaborativo pela interação entre redes e ruas. $\mathrm{O}$ evento criado como primeira convocatória do MPL em São Paulo (02 de junho de 2013) teve 20. 500 confirmações e foram deixadas 10. 500 mensagens públicas. Neste dia a maior Autoridade foi a página do Estadão, depois a do Passe Livre São Paulo, AnonymousBrasil, NINJA e CartaCapital.

No dia 13 de junho, considerado o dia da virada no rumo dos acontecimentos por ter sido marcado pela intensa violência policial (provocando maior empatia e solidariedade às manifestações), o levantamento apontou que $62 \%$ dos usuários tinham percepção positiva das manifestações, $16 \%$ expressaram rejeição e $22 \%$ das postagens eram de caráter neutro. Os assuntos de maior repercussão nas mensagens foram o apoio aos protestos contra o aumento das passagens (27\%), repúdio à violência policial (19\%, o que representa percentual maior que o dobro das ocorrências anteriores), manifestações de adesão às convocações, confirmação de comparecimento aos próximos eventos, postagens de fotos (13\%), mensagens contra o aumento das passagens, mas que não mencionaram apoio ou não aos atos nas ruas (10\%), crítica à cobertura da grande imprensa (9\%), crítica aos manifestantes acusados de depredarem o patrimônio público e de atos vandalismo (7\%), mensagens de descrença no potencial de transformação das manifestações (5\%), críticas ao PT e ao prefeito Fernando Haddad (6\%), críticas ao PSDB e ao governador Geraldo

\footnotetext{
${ }^{36}$ De acordo com o documento: "Um grafo é representado por um conjunto de pontos ou nós chamados de vértices que são ligados por retas, denominadas arestas. Para efeito dessa pesquisa, a página ou perfil no Facebook é um vértice ou nó. A ligação entre perfis se dá pelas arestas e representa o compartilhamento de uma postagem. A grosso modo, um perfil com grande confluência de arestas é relativamente mais importante que outro que possui menos arestas atraídas para si. (...) A métrica HITS atribui dois valores à cada nó: HUB e Autoridade. A autoridade estima o valor do conteúdo de cada página ou nó a partir do número de compartilhamentos de suas postagens. Os HUBs avaliam o valor de suas ligações (links) para outras páginas ou nós"
} 
Alckmin $(2 \%)$ e mensagens dos que acreditavam apenas no voto como instrumento de transformação (2\%). As maiores autoridades foram o Estadão, a página 'A Verdade Nua \& Crua' e o Occupy Brazil. O perfil do Passe Livre São Paulo caiu para a $13^{\mathrm{a}}$ posição.

Depois da virada, as reivindicações se ampliaram, e as vozes das ruas passaram a ecoar "não é por 20 centavos, é por direitos!". A exigência era pelo direito à cidade, pela liberdade de expressão, pela não criminalização dos movimentos sociais, pela democracia direta e outras pautas. As maiores Autoridades nas redes foram "Movimento Contra Corrupção", AnonymousBrasil e jornal Estadão.

No dia 20, que registrou maior mobilização popular nas ruas, as buscas retornaram mais de 300 mil mensagens. As maiores Autoridades foram a página do AnonymoysBrasil e do Movimento Contra Corrupção. A página do Passe Livre São Paulo já não aparecia mais entre as 20 primeiras Autoridades.

Percentual de assuntos nas redes sociais (jun/13)
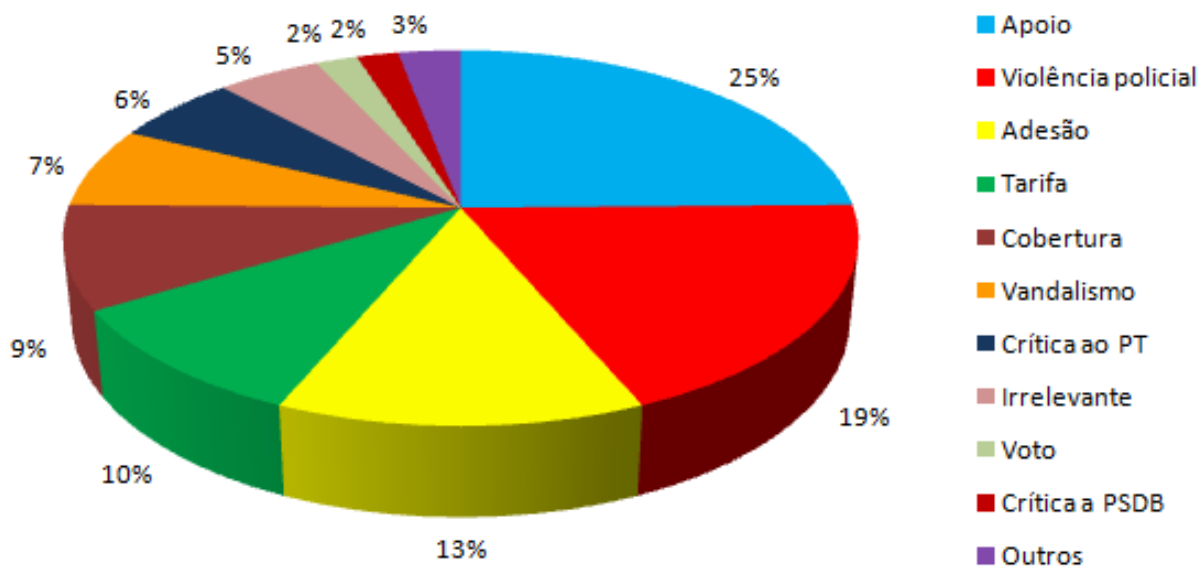

Gráfico 1. Fonte: http://interagentes.net/?p=62

O relatório conclui que a comunicação em redes permitiu elevado poder de automobilização social sem estrutura central (sem partidos, sindicatos), o surgimento de novas Autoridades alternando com a mídia tradicional (que não deixou de aparecer no topo) e a horizontalização da circulação informacional. Observou também que, embora os velhos 
veículos de Comunicação (como o Estadão) tenham permanecido como importante "Autoridade", tiveram mau desempenho como HUBs, o que demonstra que apesar de "subirem" muito conteúdo compartilhado, não interagem em rede, "não ecoam outras narrativas" diz o relatório. Porém, com uma visão um tanto entusiástica sobre o potencial das redes sociais e talvez quase ingenuamente subestimando as mídias tradicionais, afirma que os grandes veículos não tem capacidade de articulação, pouca influência exerceram nas mídias sociais e que suas linhas editoriais se renderam à força das redes e ruas. Para reforçar esse argumento, lembrou-nos dos episódios em que a velha mídia teve de "recuar" mediante as críticas das redes sociais: o exemplo da "desautorização" ao vivo do discurso de 'Datena', o reconhecimento do erro de Arnaldo Jabor, a frequente hostilidade à rede Globo e seus repórteres durante os protestos, o editorial cínico do Jornal Nacional no dia 17 que menciona sua isenção na cobertura das manifestações.

Ponto importante a ser destacado nesse levantamento é a afirmação de que os "nós pobres" conseguiram "viralizar" seus conteúdos ${ }^{37}$, muitas vezes com projeção e impacto superiores aos das produções de canais melhor estruturados. A cobertura ao vivo das manifestações feita pelos próprios atores não apenas rivalizou com aquela realizada pela mídia formal, como injetou o sentimento de potência nos indivíduos comuns, que agora poderiam fazer circular seus próprios significados, com maior grau de relevância do que aqueles dados pelas estruturas tradicionais de poder simbólico.

Entretanto a construção de significado na mente das pessoas é uma fonte de poder mais decisiva e estável. A forma como as pessoas pensam determina o destino de instituições, normas e valores sobre os quais a sociedade é organizada. Poucos

\footnotetext{
${ }^{37} \mathrm{O}$ relatório se refere ao vídeo de Marcel Bari, que teve mais de 110 mil compartilhamentos (o facebook informa que o conteúdo não está mais disponível) e ao vídeo que mostra um policial quebrando o vidro da viatura, que contabilizou mais de 2 milhões de visualizações no youtube (antes do vídeo começar, o Youtube adverte que o conteúdo é impróprio e pergunta se o visitante pretende visualizá-lo mesmo assim). Disponível em: https://www.youtube.com/watch?v=kxPNQDFcR0U\&oref=https\%3A\%2F\%2Fwww.youtube.com $\% 2$ Fwatch\%3Fv\%3DkxPNQDFcR0U\&has_verified=1
} 
sistemas institucionais podem perdurar baseados unicamente na coerção. Torturar corpos é menos eficaz que moldar mentalidades (...) É por isso que a luta fundamental pelo poder é a batalha pela construção de significado na mente das pessoas. (...) Assim, a mudança do ambiente comunicacional afeta diretamente as normas de construção de significado e, portanto, a produção de relações de poder. (CASTELLS, 2013, p. 14-15)

Os vídeos gravados por celulares iam direto para up load nas plataformas digitais (Youtube, Facebook), sem edição. O conteúdo produzido pelos manifestantes chegava a conhecimento público quase simultaneamente, portanto, antes daquele divulgado pelas mídias tradicionais. Quando se ligava a TV, ou se lia os jornais, o que se via era um choque de enquadramentos. As edições da velha mídia simplesmente invisibilizavam aspectos imprescindíveis que os manifestantes não deixavam escapar ${ }^{38}$. As denúncias de manipulação da imprensa viralizaram e os protestos passaram a incluir em suas pautas o ataque aos oligopólios midiáticos, despertando o debate da regulação de Meios em favor da democratização do acesso à informação ${ }^{39}$. O Mídia Ninja ${ }^{40}$ e o Fora do Eixo $^{41}$ capitanearam o debate e logo sentiram os efeitos de uma pesada ofensiva das grandes corporações. Dois meses depois do início das manifestações, os fundadores Bruno Torturra, do Mídia Ninja e Pablo

\footnotetext{
${ }^{38}$ Nesse sentido cumpre destacar o relevante papel dos vários coletivos na denúncia dos abusos cometidos contra manifestantes através do enfrentamento midiático pela transmissão ao vivo dos acontecimentos. Muitos desses coletivos midiativistas foram criados por ocasião das manifestações de 2013 e deram continuidade às suas atividades até os dias atuais. São importantes exemplos: Coletivo Mariachi, cujos vídeos sobre as manifestações tiveram inúmeros compartilhamentos nas redes sociais e repercussão nas redes tradicionais de comunicação; Coletivo Projetação, que conferiu importante efeito estético-político às manifestações com suas projeções sobre suportes simbólicos, como prédios representativos do poder público, camburões de polícia, entre outros. Conferir respectivamente: https://www.youtube.com/user/coletivomariachi; https://www.facebook.com/plataformaprojetacao
}

${ }^{39}$ Em 30 de abril de 2009, no julgamento da ADPF n. 130, o STF considerou que a Constituição Federal de 1988 não recepcionou a Lei de Imprensa (L. 5.250/1967) em sua integralidade. Promulgada durante a ditadura, a lei foi considerada um óbice à liberdade de expressão. Atualmente todos os debates sobre a necessidade de regulação da imprensa encontram forte resistência por parte dos grandes grupos de comunicação.

${ }^{40}$ NINJA, sigla para Narrativas Independentes, Jornalismo e Ação, é um coletivo de comunicação engajado socialmente, que tem como premissa a lógica colaborativa de criação e distribuição de informação em rede. Conferir: https://ninja.oximity.com/partner/ninja/about

${ }^{41}$ Fora do Eixo é uma rede de colaboração, da qual saiu o Mídia Ninja, composta por vários coletivos de cultura que trabalham por colaborativismo e associativismo. Conferir: http://foradoeixo.org.br/historico/carta-de-principios/ 
Capilé, do Fora do Eixo, foram entrevistados ${ }^{42}$ no programa Roda Viva, da TV Cultura e bombardeados por perguntas como: "vocês consideram o que fazem jornalismo?" “como fazem para se sustentar?" "nós queremos entender seu modelo de negócio, vocês estão imaginando criar uma empresa?" Após essa entrevista, a mídia tradicional promoveu uma verdadeira cruzada contra os coletivos, através de matérias que iam desde a desqualificação de seu modelo de jornalismo a denúncias de que eles eram sustentados por dinheiro público, passando ainda por denúncias de sexismo e tentativas de associar sua imagem a interesses de partidos de esquerda $(\text { SOLHA, 2013) })^{43}$.

Tamanha sanha despertou o comentário dissonante do colunista do O Globo, Francisco Bosco $(2013)^{44}$ :

\begin{abstract}
Uma enxurrada de comentários e compartilhamentos chegou ao veredicto mais rápido de que já tive notícia na era das redes sociais. De Herói a arauto da contemporaneidade, Pablo Capilé (e o Fora do Eixo) rapidamente se transformou em ditador, estelionatário, sexista, explorador da força de trabalho alheio, manipulador de jovens mentes indefesas, líder de seita, entre outros epítetos igualmente glamourosos. Ma na transformação do príncipe em sapo, há mais economia do narcisismo do que revelações factuais ou argumentações arrasadoras.
\end{abstract}

Mais uma vez, entrava em ação o poder da rede colaborativa da velha mídia com seus velhos meios.

\title{
3.2.2 As manifestações nas velhas redes
}

Diferentemente da conclusão da Cartografia do Interagentes, a mídia tradicional teve relevância no desenvolvimento das manifestações. No início os meios de comunicação (e também os dirigentes públicos) tentaram criminalizar os eventos, retratando-os como atos de vandalismo, privilegiando o enfoque da destruição do patrimônio público e privado. Os

\footnotetext{
${ }^{42}$ Disponível em: https://www.youtube.com/watch?v=vYgXth8QI8M

${ }^{43}$ Conferir: http://veja.abril.com.br/noticia/brasil/o-ninja-do-pt / http://oglobo.globo.com/brasil/ninjas-querem-verba-oficial-para-sobreviver-9343258 http://www.cartacapital.com.br/sociedade/fora-do-eixo-6321.html http://www.cartacapital.com.br/blogs/feminismo-pra-que/ex-integrantes-do-fora-do-eixodenunciam- machismo-4388.html

${ }^{44}$ Disponível em: http://oglobo.globo.com/cultura/acusados-acusadores-9509047
} 
manifestantes sempre eram narrados como os iniciadores dos confrontos violentos, cabendo à polícia tão somente cumprir seu papel de proteger a cidade. As autoridades públicas foram cobradas para atuarem de forma mais enérgica na coibição dos protestos. Havia uma tentativa de direcionamento da opinião pública contra as mobilizações através do velho discurso do medo, da ameaça que estas representariam contra a cidade e os "homens de bem". O tom condenatório era ainda mais explícito nos editoriais e nas colunas de opinião. No dia 13 de junho (como vimos, dia de maior intensidade da repressão policial em São Paulo desde o início dos protestos), com uma narrativa próxima àquela de Applebaum, Arnaldo Jabor assim se manifesta em sua coluna no Jornal da Globo ${ }^{45}$ (SOLHA, 2013):

\begin{abstract}
Mas afinal, o que provocou um ódio tão grande contra a cidade? Só vimos isso quando a organização criminosa de São Paulo queimou dezenas de ônibus. Não pode ser por causa de vinte centavos. A grande maioria dos manifestantes são filhos de classe média, isso é visível! Ali não havia pobres que precisassem daqueles vinténs, não. Os mais pobre ali, eram os policiais apedrejados, ameaçados com coquetéis molotovs, que ganham muito mal. No fundo, tudo é uma imensa ignorância política, é burrice misturada a um rancor sem rumo. Há talvez a influência da luta na Turquia, justa e importante contra o islamismo fanático. Mas aqui? Se vingam de quê? (...) Porque não lutam contra o Projeto (sic) de Emenda Constitucional 37 ? A PEC 37, por exemplo, que será votada no dia 26 no Congresso Nacional para impedir o MP de investigar? Talvez eles nem saibam o que é a PEC 37 (...) Realmente, esses revoltosos de classe média não valem nem vinte centavos.
\end{abstract}

No mesmo dia e com a mesma tônica, o editorial "Chegou a hora do basta", de O Estado de São Paulo ${ }^{46}$ :

(...) Atacada com paus e pedras sempre que tentava conter a fúria dos baderneiros, a PM reagiu com gás lacrimogêneo e balas borracha. $\mathrm{O}$ saldo foi de 20 pessoas detidas e de dezenas com de ferimentos leves, entre elas policiais (...) A PM agiu com moderação, ao contrário do que disseram os manifestantes que a acusaram de truculência para justificar seus atos de vandalismo (...) De Paris, o governador disse que "é intolerável

\footnotetext{
${ }^{45}$ Disponível em https://www.youtube.com/watch?v=EN8bXvMgCks Acesso em 26 mai/2015

${ }^{46}$ Disponível em http://opiniao.estadao.com.br/noticias/geral,chegou-a-hora-do-basta-imp, 1041814 Acesso em 26 mai/2015
} 
a ação de baderneiros e vândalos" (...) Espera-se que ele passe dessas palavras aos atos e determine que a PM aja com o máximo rigor para conter a fúria dos manifestantes, antes que ela tome conta da cidade.

E ainda "Retomar a Paulista", da Folha de São Paulo ${ }^{47}$ :

Pior que isso, só o declarado objetivo central do grupelho: transporte público de graça. O irrealismo da bandeira trai a intenção oculta de vandalizar equipamentos públicos e o que se tom por símbolos do poder capitalista. O que vidraças de agências bancárias têm a ver com ônibus? (...) Sua estratégia para atingir a opinião pública é prejudicar o número máximo de pessoas. É hora de pôr um ponto final nisso. Prefeitura e Polícia Militar precisam fazer valer as restrições já existentes para protestos na avenida Paulista, em cujas imediações estão sete grandes hospitais.

O que se seguiu já se sabe: inúmeros vídeos produzidos por manifestantes (muitos transmitidos ao vivo por canais de streaming, como Mídia Ninja), circulando pelas redes sociais e desmentindo as versões da mídia, que então, se viu obrigada a retificar suas veiculações. A rejeição à imprensa aumenta. Carros das equipes de jornalismo são depredados, repórteres rechaçados. No Rio de Janeiro o povo gritava: "a verdade é dura, o Globo apoiou a ditadura". Expulsa das ruas, a imprensa passa a fazer a cobertura por imagens feitas dos helicópteros. No canal de TV aberta Band, o apresentador Datena fez uma enquete ao vivo perguntando se o público era a favor das manifestações com quebra-quebra. O resultado é um retumbante "sim". O apresentador acredita que o público não entendeu direito, pois na tela a pergunta projetada é "Você é a favor deste tipo de protesto?" Então ele pede para a produção zerar esta pesquisa e começar outra, que projetava a seguinte pergunta: "Você é a favor de protesto com baderna?" A resposta positiva foi ainda mais expressiva. Ao questionamento de Datena "Será que formulamos mal a pergunta?"48, Zizek responderia: "Não, porque sua respectiva ignorância não é simétrica: são as pessoas que têm as respostas, elas só não conhecem as perguntas

\footnotetext{
${ }^{47}$ Disponível em http://www1.folha.uol.com.br/opiniao/2013/06/1294185-editorial-retomar-apaulista.shtml. Acesso em 26 mai/2015

${ }^{48}$ Disponível em https://www.youtube.com/watch?v=eoPzlvxzTtM Acesso em 26 mai/2015
} 
para as quais têm (ou melhor, são)" (2012, p. 25). No dia 17, Arnaldo Jabor faz sua "autocrítica" na rádio $\mathrm{CBN}$ : "Errei na avaliação das manifestações" "49 . E na TV: "À primeira vista, esse movimento parecia uma pequena provocação inútil, que muitos criticaram, erradamente, inclusive eu...". 50 Porém, Jabor adverte "mas há dois perigos: a tentação da violência e o vazio". O colunista finaliza lembrando da importância de rejeitar a PEC $37^{51}$ e afirma que “democracia já temos, só falta reinventar a República”. A cobertura da imprensa começava a mudar o tom. As manifestações passam a ser apresentadas como atos legítimos e positivos de insatisfação contra a corrupção e a política (REYS, 2014; SOLHA, 2013). Mas ao contrário do que propôs o relatório do Interagentes, não se tratou propriamente de um "recuo", mas de uma nova estratégia para lidar com a afirmação de forças das ruas. Os meios de comunicação assumem a postura de "relatores" dos desejos das manifestações. Embutidas nisso, estavam as antigas práticas de distorção narrativa: seleção de conteúdo, doação de sentido, edição de imagens. O perigo apontado por Jabor era o da "desobediência". À multidão que clamava por democracia real, responde: "democracia, já temos".

Precisamente nesse sentido, Badiou está certo ao afirmar que hoje o nome do pior inimigo não é o capitalismo, império, exploração ou algo similar, mas democracia: é a 'ilusão democrática', a aceitação dos mecanismos democráticos como a moldura fundamental de toda mudança, que evita a transformação radical das relações capitalistas. (ZIZEK, 2012, p.23)

A reconciliação com a opinião pública permitiu maior inserção da mídia no debate. Os velhos veículos de comunicação (especialmente as organizações Globo) passaram a separar os manifestantes em duas categorias: os "manifestantes pacíficos" de um lado e os "vândalos" de outro. Os protestos pacíficos são interpretados como atos "cívicos" anticorrupção, que teriam como alvo preferencial o julgamento do Mensalão, o

\footnotetext{
${ }^{49}$ Disponível em https://www.youtube.com/watch?v=RxM4yNy35z4 Acesso em 26 mai/2015

${ }^{50}$ Disponível em http://g1.globo.com/jornal-da-globo/videos/t/edicoes/v/arnaldo-jabor-fala-sobrenovos-protestos-e-ressalta-forca-da-juventude/2640269/

${ }^{51}$ Segundo Solha (2013), as investigações de corrupção pelo Ministério Público, às quais a imprensa teria acesso privilegiado, garantiriam conteúdos de interesse midiáticos.
} 
desvio de dinheiro público associado à gestão do PT e a crise política decorrente da crise de representatividade das instituições públicas e do Estado. Os Partidos de oposição abraçaram essa narrativa, associando corrupção ao PT. Nos dias 18 e 19 de junho circula nas redes sociais um vídeo $^{52}$ atribuído ao Anonymous Brasil, onde um homem com a máscara de Guy Fawkes ${ }^{53}$ afirma o apartidarismo e ausência de liderança das manifestações, que funcionariam espontaneamente por autoconvocação (REYS, 2014; SOLHA, 2013). O vídeo elenca "causas de cunho moral que são unanimemente aceitas", chamadas “As 5 causas" dos protestos:

1. Não á PEC 37. 2. Saída imediata de Renan Calheiros da presidência do Congresso Nacional (sic). 3. Imediata investigação e punição de irregularidades nas obras da Copa, pela Polícia Federal e Ministério Público Federal. 4. Queremos uma lei que torne a corrupção no Congresso crime hediondo. 5. Fim do foro privilegiado, pois ele é um ultraje ao artigo $5^{\circ}$ da nossa Constituição!

Apesar do site Anonymous Brasil ter negado a autoria do vídeo, a RBS, afiliada à Rede Globo no Rio Grande do Sul, veiculou uma entrevista $^{54}$ que teria feito com dois integrantes mascarados do Anonymous, onde afirmam que "o foco principal é tentar destruir a corrupção, né, porque é ela que acaba com todo o resto". O final do vídeo mostra manifestantes com o rosto pintando de verde e amarelo e um dos cartazes onde se lê "verás que um filho teu não foge à luta". O repórter assinala que a vitória no arquivamento da PEC 37 e a aprovação do projeto de tornar a corrupção crime hediondo representa estímulo a novas causas. A retratação pública da imprensa fazia parte da estratégia de delineamento das pautas difratadas (REYS, 2014; SOLHA, 2013).

\footnotetext{
${ }^{52}$ Disponível em https://www.youtube.com/watch?v=v5iSn76I2xs Acesso 26 mai/2013

${ }^{53} \mathrm{O}$ Anonymous é um coletivo de viés anarquista conhecido pelo hackativismo, que atua de forma anônima e colaborativa através da internet em favor da liberdade de expressão na defesa de pautas globais. Tem como estética o uso da máscara inspirada no personagem da graphic novel (que virou filme) V de Vingança. A máscara é uma referência à Guy Fawkes, soldado inglês católico, envolvido na "Conspiração da Pólvora", que tinha como objetivo matar o rei protestante Jaime I (início do séc. XVII). Para maior referência cf. http://www.anonymousbrasil.com/sobreanonymous/

${ }^{54}$ Disponível em http://globotv.globo.com/rbs-rs/teledomingo/v/membros-do-anonymous-falamsobre-seus-objetivos/2664894/ Acesso 26 mai/2013
} 
A insistência da mídia na crise de representatividade política, não apenas procurou dar a entender que se tratava de um problema próprio das instituições políticas brasileiras, fruto da administração corrupta, que nada teria a ver com um modelo de democracia que dá sinal de estiramento no mundo todo, como ainda dissimulou o fato de ela mesma ser objeto dessa crise, uma vez que faz parte de uma estrutura institucional sem reverberação democrática. Aqueles que foram às ruas através das redes sociais, utilizaram um canal alternativo para fazer ecoar suas vozes porque já que estavam excluídos do espaço público por qualquer outro meio, inclusive deixando isso bem claro durante os protestos (LIMA, 2013).

Por eventualidade ou não, após a tentativa de captura de sentido pela imprensa e por setores conservadores, nas ruas e nas redes começaram a aparecer narrativas nacionalistas e de extrema direita. Desde o início das manifestações os partidos, organizações e qualquer símbolo de poder institucionalizado foram rechaçados, mas apenas refletiam o sentimento de disjunção entre a democracia real e a formal. No dia 20 de junho, quando milhões de pessoas compareceram aos protestos, manifestantes que apresentavam símbolos partidários de esquerda sofreram agressões físicas. O apartidarismo dava lugar ao mais ostensivo antipartidarismo. Não era mais só a imprensa que estava mudando o tom, mas também as ruas (PILATTI, 2014; REYS, 2014; SECCO, 2013; SOLHA, 2013).

A disputa pelo comum $^{55}$, em termo negriano, transbordava para o campo da significação. Era a produção de sentido sobre as manifestações que estava sendo disputada. Intelectuais, professores, estudantes, toda a sociedade civil de maneira geral, passaram a se mobilizar para criar espaços abertos à reflexão sobre os acontecimentos e de resistência contra apropriações oportunistas (PILATTI, 2014).

(...) a luta pela interpretação dos protestos não é apenas "epistemológica"; a luta dos jornalistas e teóricos sobre o

55 "O comum compreenderia então os ambientes de recursos compartilhados gerados pela participação de muitos, e que constituem o tecido produtivo essencial da metrópole contemporânea. Se fizermos esta conexão entre o comum e a produção, poderemos pensar na economia, no poder, nos rendimentos e nos conflitos" (SOTO, 2014, p. 145) 
verdadeiro teor dos protestos é também uma luta "ontológica", que diz respeito à coisa em si, que ocorre no centro dos próprios protestos. (ZIZEK, 2013, p. 103)

Um importante instrumento para constatação dos mecanismos de manipulação da velha imprensa é a pesquisa realizada pelo coletivo de comunicação Intervozes, divulgada na publicação "Vozes Silenciadas. Mídias e Protestos" $"$. A investigação avaliou a cobertura das manifestações através de matérias dos jornais online "O Estado de São Paulo", "Folha de São Paulo" e "O Globo" durante os 19 primeiros dias de protestos. A despeito de algumas limitações metodológicas, o relatório chega a conclusões interessantes, dentre as quais se destaca a avaliação sobre as matérias que faziam referências valorativas às ações dos participantes das manifestações. De todo o universo analisado das matérias que abordaram as manifestações, em $73 \%$ não havia referência positiva às ações dos atores (entende-se que neste percentual se encontram matérias com menção negativa e matérias neutras ou indistinguíveis), em $22 \%$ havia menção positiva para manifestantes, $4 \%$ para policiais e $3,7 \%$ para ambos. No início dos protestos prevaleceram as qualificações positivas para policiais, já nos dias 17, 18 e 19, para manifestantes (portanto, depois da virada do dia 13). A pesquisa ressalta que as classificações positivas se encontram majoritariamente no contexto de apoio às manifestações em atos pacíficos fora do país e nas análises de famosos.

A análise de atores em descrição negativa mostra que em $49 \%$ da amostra não há menção negativa (dentre os quais estão as menções positivas e "neutras"), sendo que $60 \%$ destas matérias não têm foco descritivo, mas as manifestações aparecem apenas de forma repercussiva ou como pano de fundo. Dos $51 \%$ negativos, $34 \%$ qualificam manifestantes (maior pico nos dias 12 e 13 de junho), $10 \%$ policiais e $7 \%$ ambos. Na representação gráfica fica mais fácil visualizar a significativa diferença entre o percentual de manifestantes qualificados de modo positivo e

\footnotetext{
${ }^{56}$ Disponível para download em: http://intervozes.org.br/publicacoes/vozes-silenciadas-midia-eprotestos-as-manifestacoes-de-junho-de-2013-nos-jornais-o-estado-de-s-paulo-folha-de-s-paulo-eo-globo-cobriram-as-manifestacoes-de-junho/
} 
negativo. Além disso, cumpre destacar que, como vimos, os manifestantes foram classificados pela mídia como pacíficos e vândalos. Assim, sabemos exatamente quais manifestantes estão na fatia vermelha e quais estão na fatia azul. ${ }^{57}$

\section{Percentual de matérias com classificação valorativa sobre as ações dos atores (jun/13)}

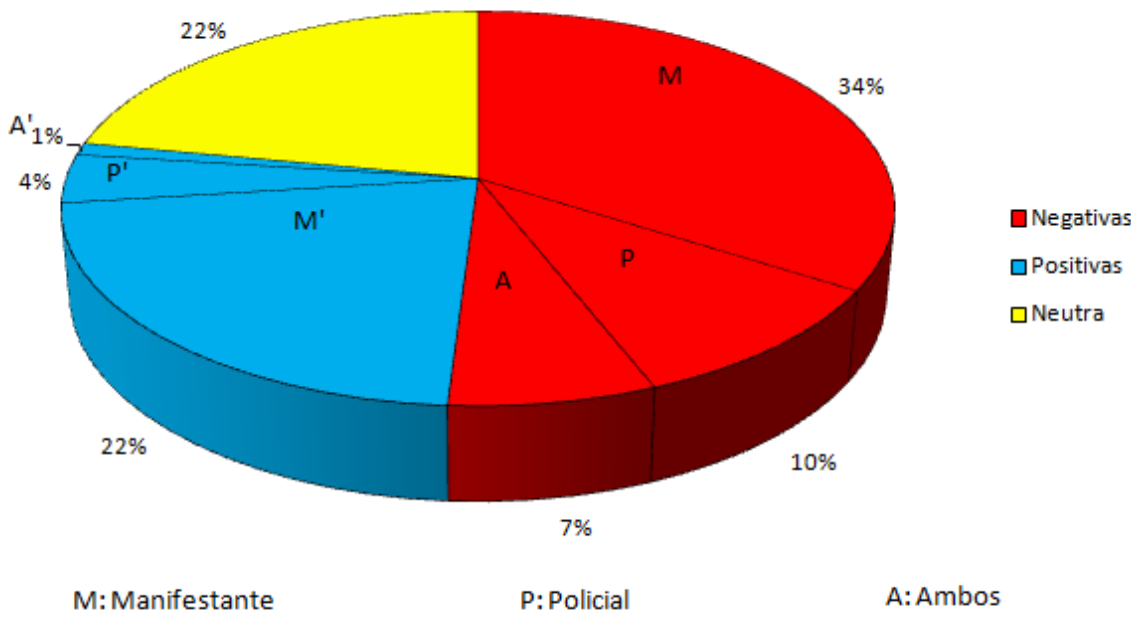

Gráfico 2. Fonte: http://intervozes.org.br/publicacoes/vozes-silenciadas-midia-e-protestos-asmanifestacoes-de-junho-de-2013-nos-jornais-o-estado-de-s-paulo-folha-de-s-paulo-e-o-globo-cobriramas-manifestacoes-de-junho/

Outro importante aspecto analisado foi o das fontes. Mais da metade (51\%) das matérias não mencionava qualquer fonte ou apenas uma. Das matérias de fonte única, $45 \%$ tinham as autoridades governamentais ou policiais como fonte. Os manifestantes representaram apenas $11 \%$ desse total total. Do universo de matérias com fontes, $47 \%$ eram de autoridades públicas e políticos, $28 \%$ eram de manifestantes, ONGs, sindicatos e $25 \%$ de atores não envolvidos com os protestos. Quando se analisou as falas diretas e indiretas de manifestantes no universo total de matérias, ficou demonstrado que $69 \%$ das matérias não traziam a fala de manifestantes, $26 \%$ traziam citação direta e $5 \%$ tinham citação indireta. A conclusão mais

\footnotetext{
${ }^{57}$ A pesquisa trabalhou com gráficos separados: um para matérias que faziam menções negativas e outro para as que faziam menções positivas. O gráfico aqui apresentado foi elaborado para o presente trabalho com o fito de melhor ilustrar o impacto de cada classificação no universo total de matérias analisadas.
} 
alarmante, entretanto, refere-se ao cumprimento do princípio do contraditório. Em apenas $23 \%$ das matérias a parte acusada foi ouvida, em $77 \%$ o princípio foi violado. Os que mais sofreram essa violação foram os manifestantes (48\%). Em 24\% das matérias, autoridades do governo e policiais eram acusados sem serem ouvidos e em 5\% ambos (manifestantes e autoridades) foram acusados e não ouvidos.

\section{Proporção de matérias com fala direta ou indireta de manifestantes (jun/13)}

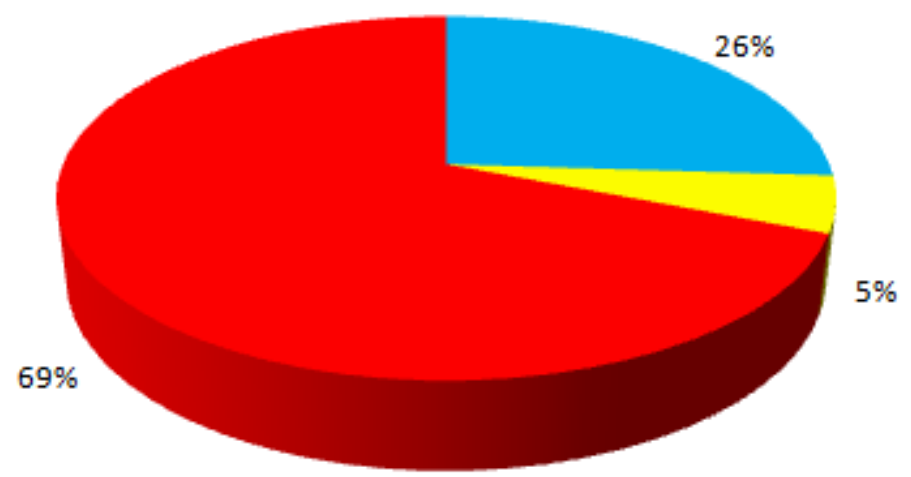

n Com fala direta (aspas)

Com fala indireta

- Sem qualquer fala

Gráfico3. Fonte: http://intervozes.org.br/publicacoes/vozes-silenciadas-midia-e-protestos-asmanifestacoes-de-junho-de-2013-nos-jornais-o-estado-de-s-paulo-folha-de-s-paulo-e-o-globo-cobriramas-manifestacoes-de-junho/

\section{Percentual de matérias que respeitam o princípio do contraditório (jun/13)}
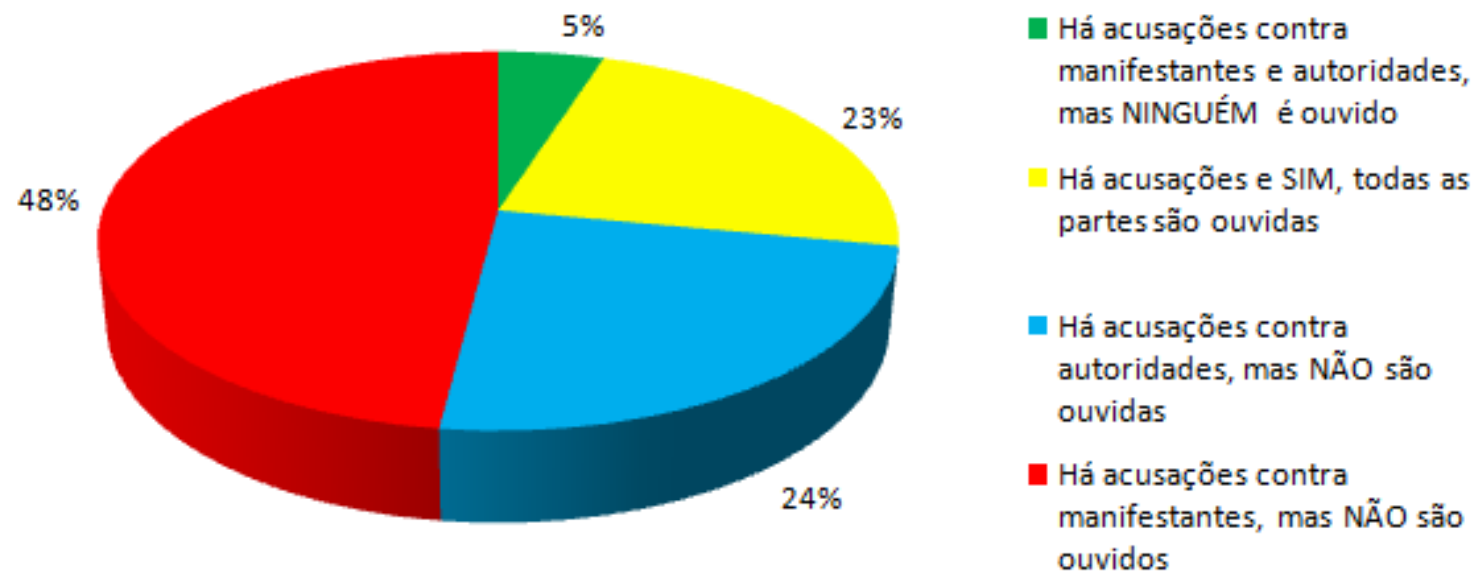

Gráfico 4. Fonte: http://intervozes.org.br/publicacoes/vozes-silenciadas-midia-e-protestos-asmanifestacoes-de-junho-de-2013-nos-jornais-o-estado-de-s-paulo-folha-de-s-paulo-e-o-globo-cobriramas-manifestacoes-de-junho/ 
A análise dos gráficos evidencia a subrepresentação dos discursos desinstitucionalizados, ao quais a vocalização é negada. A "autorepresentação" por meio dos vídeos de celulares, sem mediação, é o único canal possível destas vozes se fazerem ouvir. Resta saber por quanto tempo. 


\section{NARRATIVAS DAS MANIFESTAÇÕES E DIREITO À MEMÓRIA}

Disseste que se tua voz/ tivesse força igual/À imensa dor que sentes/Teu grito acordaria/Não só a tua casa/ Mas a vizinhança inteira. (Dado Villa-Lobos, Marcelo Bonfá, Renato Russo)

As análises anteriores revelam que a cobertura que os veículos tradicionais de comunicação fizeram das manifestações de junho de 2013, corresponde aos mecanismos de perpetuação da dominação simbólica que se realiza sobre a memória coletiva, como apontado por diversos autores ao longo do presente trabalho.

Lembramos que em Halbwachs a estabilidade da memória coletiva depende da relação entre grupo e lugar. A imagem espacial se transforma para refletir o espírito coletivo, mas ao mesmo tempo o reforça. O rompimento da estabilidade entre essas instâncias altera a própria memória coletiva. A identidade de um grupo está plasmada na matéria exterior, cujas imagens também regulam seus pensamentos. Por isso, quanto maior for o sentimento de aderência ao lugar (pertencimento), maior será a resistência. "Para que essa resistência se manifeste, é preciso que emane de um grupo" (HALBWACHS, 1990, p. 137).

Certamente os acontecimentos excepcionais também têm lugar neste quadro espacial, mas porque na ocasião certa o grupo tomou consciência com mais intensidade daquilo que ele era desde há muito tempo e até este momento, e porque os vínculos que o ligavam ao lugar se tornaram mais claros, no momento em que iam se romper. Porém, um acontecimento realmente grave sempre causa uma mudança nas relações do grupo com o lugar, seja porque modifique o grupo em sua extensão, (...) seja porque modifique o lugar (...) a partir desse momento, não será mais exatamente o mesmo grupo, nem a mesma memória coletiva; mas, ao mesmo tempo, o ambiente material não mais será o mesmo. (HALBWACHS, 1990, p. 133-134)

Poderíamos compreender assim, como todo o processo de higienização social nas cidades-empreendimento, tendo como estopim a questão da mobilidade urbana, contribuiu para o despertar de uma consciência de direito à cidade, de direito ao lugar de identidade quando esse vínculo cidadão-cidade se viu ameaçado de desvanecimento. Se no 
sentido tradicional de Halbwachs não podemos chamar o levante das manifestações de memória coletiva, uma vez que foi um evento com plurissignificados e participação de múltiplas memórias coletivas, havia entretanto, um quadro de memória social, como abordou Candau, onde consciências individuais convergiram se encontrando no desejo de vocalizar suas insatisfações. Porém, quando ocorre uma tentativa de captura e organização de sentido totalitário de um evento, como aquela que vimos nos velhos meios de comunicação sobre as narrativas das manifestações, todas as reivindicações com suas significações plurais, individuais e difusas, convergem não como reunião de forças que aumentam sua potência numa mesma ação embora com diferentes sentidos, mas toda ação é reduzida aos sentidos dados pelos interesses do poder constituído. A anarquia interpretativa decorrente das múltiplas narrativas oferecidas sobre os mesmos eventos (manifestações) arrastam seu leitor (receptor) para um "lusco-fusco epistemológico" (COHEN, 2001, p.268) instigando-o à necessidade de investigar, de recorrer a várias fontes para que ele próprio possa decidir pela(s) narrativa(s) que melhor corresponde(m) à realidade, ou pelo menos à conclusão que chegou sozinho sobre o sentido dessa realidade. Os velhos grupos de poder de comunicação estabilizam a insegurança criada pela heterogeneidade discursiva oferecendo um produto (mercadoria) com uma semântica fechada sobre si mesma. Ao fixar o sentido, a velha mídia "poupa" ao receptor o esforço cognitivo, porém, nunca o consegue em sua plenitude, pois sempre teve de lidar com tensões de conteúdos contra-hegemônicos ${ }^{59}$. Na era da comunicação em redes digitais, esses conteúdos alcançam o público numa escala sem precedentes

\footnotetext{
${ }^{58}$ Margaret Cohen utiliza o termo inspirada na "anarquia da meia-luz do cotidiano" (Lukács) em texto onde a autora analisa o gênero literário chamado por Benjamin de "literatura panorâmica", que oferece ao leitor múltiplas representações da realidade hiperestimulante das primeiras cidades urbanas no início da modernidade no séc. XIX (COHEN, Margaret. A literatura panorâmica e a invenção dos gêneros cotidianos. In: CHARNEY, Leo; SCHWARTZ, Vanessa R. (Orgs.). O cinema e a invenção da vida moderna. São Paulo. Cosac \& Naify, 2004. p.259-288.

${ }^{59} \mathrm{Em}$ Cadernos do Cárcere, Gramsci esclarece que à toda tentativa de hegemonia, cujo principal instrumento ideológico é a imprensa, correspondem forças contra-hegemônicas que estabelecem tensões no projeto hegemônico. O jornalismo alternativo seria uma dessas forças. GRAMSCI, Antonio. Cadernos do Cárcere. COUTINHO, Carlos Nelson et al (Orgs.). Rio de Janeiro. Civilização Brasileira, 2002, v.3.
} 
representando uma ameaça até então jamais experimentada pela velha mídia.

Vimos em Halbwachs que as memórias individuais precisam concordar entre si para formar a memória coletiva, mas o autor não se interessou pelos mecanismos de poder inscritos nessa formação, se ocupou apenas da questão identitária e comunicacional. É Pollak quem problematiza a estabilização de significados da memória como fruto de operações de poder e então privilegia as narrativas orais dos marginalizados. Em junho de 2013 essas oralidades foram vocalizadas pelas vozes das ruas e se tornaram paisagens gravadas nos vídeos de celulares dos participantes anônimos. Assim se fizeram ver e ouvir, passando da invisibilidade e do silêncio ao primeiro plano de percepção dos olhos e ouvidos de toda a nação. Mas a paisagem que circulava nas redes sociais contrastava com aquela que circulava na grande imprensa. Não "colou" o discurso maniqueísta de "mais pobres eram os policiais"; "atacada, a PM reagiu"; "a PM agiu com moderação". O choque narrativo revelou uma dissonância discursiva, que trouxe à superfície da consciência toda a manipulação implícita, aquilo que Cauquelin ${ }^{60}$ chamou de "falha". Assim como Halbwachs vê na imagem espacial acúmulos vivos de memória coletiva, Cauquelin entende que a paisagem objetivada não tem existência senão enquanto predesignação discursiva, isto é, a narrativa antecede o topos (lugar). A paisagem (imagem que é sempre um recorte) é constituída por autoridades implícitas (saberes), por isso, aqueles que vêem nela uma imanência originária, reproduzem construções realizadas pelo intelecto. "Porque esse originário é, a meus olhos, composto de milhares de dobras,

\footnotetext{
${ }^{60}$ Cauquelin é filósofa, artista plástica e crítica de arte. As análises aqui expostas são fruto de suas reflexões sobre a naturalização de equivalência entre os termos natureza e paisagem, que ela critica como uma construção cognitiva, fruto de discursos de poder orientados a determinar nossas categorias de percepção. Embora suas análises sejam voltadas para um estudo de estética, as imbricações de conceitos filosóficos em seu pensamento como: discurso, imagem, poder, saber, memória, linguagem e autoridade, servem para colmatar os espaços que porventuram ainda tenham restado abertos após a articulação entre as teorias selecionadas, enriquecendo assim as conclusões.
} 
de milhares e milhares de memórias (...). Desdobrar essas dobras é, claramente, criticar as 'evidências"” (CAUQUELIN, 2007, p.31).

Desdobrar em sentido político é tanto resistir à dobra, isto é, "não se deixar dobrar", quanto descomplicar ${ }^{61}$, perceber que as interpretações que as velhas mídias brasileiras fizeram sobre as manifestações visavam estender a toda sociedade, valores que na realidade atendem apenas aos interesses de grupos de poder. A esses valores, Marx chamou ideologia de classe, Benjamin, bens culturais, pelos quais os vencedores submetem os vencidos. Porém, parece que agora o anão enxadrista titereiro benjaminiano se lançou ao domínio das artes da ventriloquia, tentando fazer as multidões das ruas ecoarem sua própria e única voz. Se no começo dos protestos não foi possível o "enquadramento de memória", como nos ensinou Pollak, pois que, as memórias subterrâneas sublevadas, associadas à tecnologia de informação móvel, insistiram em desmoralizar os vetustos métodos de manipulação das mídias tradicionais, num segundo momento, estas mídias tentaram "aniquilar" as memórias coletivas que se exibiram fulgurantes na potência da contradição do sistema como crítica deste, mas não para transformá-las em história (não ainda, pelo menos) ${ }^{62}$, mas sim para oferecer em troca um simulacro de memória coletiva, que com a repetição e reprodução, é tida como verdade e assim é legada para a história. Ao criar as condições de opiniões pasteurizadas, a mídia tradicional fabrica a verdade, monopoliza o "saber" e assim aumenta seu poder, como ensinou Foucault. O modo como os veículos tradicionais de comunicação realizam sua autoridade para dizer a verdade é se colocando como meios imparciais de transmissão da informação, prática que Barbosa revelou ser comum desde os primórdios da imprensa brasileira. A pergunta dirigida à Mídia

\footnotetext{
61 Tem origem na palavra "plica", dobra; "plicado": dobrado em várias pregras. Assim, descomplicar é tirar as dobras e vice-versa. ETIM. lat. plǐcō, ās, āre, ūī, āvī, ātum, t.: dobrar, enroscar. Referências: SILVA, Amós Coêlho da. Dicionário Latino-Português. Petrópolis. Ed. Vozes , 2009./ HOUAISS, Antonio et al. Dicionário da Língua Portuguesa, Rio de Janeiro, Objetiva, 2001.

${ }^{62}$ Como visto no primeiro capítulo, em muitos autores história é o oposto de memória, pois associada a um passado morto, enquanto memória são os valores vivos praticados no presente, transmitidos por gerações e que dão cognição ao passado.
} 
Ninja e ao Fora do Eixo "vocês consideram o que fazem jornalismo?" (leiase: "um conteúdo que assume um posicionamento ideológico pode ter credibilidade?") visa desqualificar não apenas esses canais diretamente, mas principalmente as vozes das ruas que eles fazem ecoar.

Barbosa afirmou que os jornalistas do início da República gozavam de autoridade não apenas porque monopolizavam a verdade por meio de um saber neutro, mas também porque detinham o domínio do conhecimento inédito antes do público. As novas tecnologias de informação e o midiativismo desbancaram esse papel. A avaliação de comportamento nas redes sociais durante as manifestações demonstrou que os canais de streaming gozavam de muito mais prestígio que a mídia tradicional justamente por exibirem ao vivo material bruto não editado. Sem dúvida esse privilégio da comunicação imediata promovida pelas redes sociais, foi determinante para a "falha" que interrompe a naturalização do que é exibido como evidente, conforme acima descrito por Cauquelin. Não obstante, apesar do corte cognitivo provocado por essas falhas, entenda-se, ainda que as vozes (e imagens) das ruas tenham rivalizado com os veículos tradicionais e ganhado uma projeção antes só possível por meios de comunicação de massa, as análises do capítulo anterior deixaram claro que estes últimos ainda exercem grande capacidade de dirigismo ao reportarem quais seriam as pautas das ruas: arquivamento da PEC 37, fim da corrupção, crise de representação.

Além disso, o poder que os meios de mídia tradicionais têm de afetar a memória coletiva se exerce não apenas sobre o presente, mas também se lança sobre o futuro. Mnemosyne tem o dom da onisciência, sabendo o que passou, o que se passa e o que passará. Carrega o bastão da sabedoria, que lhe dá acesso à verdade. Aqueles que dominam a memória detêm o saber $\mathrm{e}$ o poder de controlar o passado, o presente e o futuro. Por isso os meios de comunicação são "lugares de memória", como descrito por Nora, operados por "senhores da memória e do esquecimento" (Le Goff). Porém, a memória-mercadoria, assim trabalhada por Huyssen, está longe da memória 
mítica grega capaz de alcançar a verdade, mas tem a capacidade de fabricar seus próprios mitos, suas próprias verdades. É esse poder simbólico tal como tratado por Bourdieu, que através da ideologia apresenta, representa e reapresenta a memória no sentido que garante a permanência de sua dominação.

\begin{abstract}
A análise do discurso jornalístico se faz importante e necessária já que este, enquanto prática social, funciona em várias dimensões temporais simultaneamente: capta, transforma $e$ divulga acontecimentos, opiniões e ideias da atualidade - ou seja, lê o presente - ao mesmo tempo em que organiza um futuro - as possíveis consequências desses fatos do presente - e assim, legitima, enquanto passado - memória - a leitura desses mesmos fatos do presente, no futuro (MARIANI, 2001, p.33).
\end{abstract}

Enquanto as grandes mídias dispõem de Centros de Documentação próprios e de um Depósito Legal que salvaguardam sua memória, tornandoa disponível à reapresentação futura, portanto, à renovação da violência simbólica nela representada, as imagens das ruas, ou se quisermos, vozes em movimento, que circularam (e algumas ainda circulam) livremente na internet, não gozam de nenhuma garantia, nem presente, nem futura. Estão hospedadas em sites de empresas privadas, logo, sua permanência depende da existência destas últimas. Além disso, vimos que a própria recuperação na internet é precária, pois sua circulação depende de sistemas algorítmicos determinados por programadores e cada vez mais os conteúdos sofrem a influência de patrocínios e de um conjunto de estratégias de Marketing Digital, necessitando de atualização permanente. Muitos vídeos produzidos durante as manifestações que entraram na internet diretamente pelas redes sociais, simplesmente se perderam, pois estas redes vendem instantaneidades, não são sites buscadores. Embora disponham de mecanismos de buscas, estes são muito rudimentares. É possível encontrar muitos vídeos sobre as manifestações no Youtube, porém na lista de rankeamento, os vídeos que mais aparecem nas primeiras páginas de busca são gravações de telejornais ou versões editadas como documentários ou clipes musicais que "espetacularizam" as manifestações. 
Assim, ainda que a internet seja um poderoso instrumento para pluralizar a circulação de informações, essa circulação não acontece de maneira tão isonômica, muito menos, completamente isenta de interesses dos grandes grupos de poder, que cada vez mais tendem a se associar, formando verdadeiros oligopólios. Ronaldo Lemos chamou atenção para a divulgação de que alguns jornais passariam a veicular seus conteúdos diretamente no Facebook e para o estudo que reconheceu que o conteúdo que circula em cada timeline prioriza o perfil ideológico do usuário. Não é difícil perceber que tal combinação só pode conduzir a uma ditadura informacional. Como percebeu Bruno Cava: "Meu universo de conhecimento aumentou enormemente com o Google e Wikipedia, porém, meu conhecimento do desconhecido contraiu" (2013, p.61).

Embora possamos reconhecer valor histórico, político, cultural e social no conjunto de vídeos produzidos por cidadãos comuns e midialivristas durante as manifestações de junho de 2013, sua relevância memorialística não se materializa por uma tutela efetiva do direito à memória. Isso, porque embora tenha sido demonstrada a fundamentalidade desse direito, sua efetivação é política. Trata-se na realidade de um direito eminentemente político, transversalizado pela efetivação de outros direitos como os direitos culturais, direito à informação, à verdade, à liberdade de expressão. O caráter político desse direito restou objetivamente claro quando se abordou os instrumentos disponíveis à sua efetivação, quer se trate de patrimônio cultural, de justiça de transição ou de tutela da produção intelectual nacional. Em qualquer desses aspectos da memória, a negociação com os poderes constituídos sempre esteve presente e suas manipulações também.

A preservação dessa memória, produzida espontaneamente por pessoas anônimas na forma mais genuína de uma poética política, importa não só por revelar discursos plurais contra-hegemônicos em contraste com as narrativas monolíticas que forjam uma memória coletiva e aguardam o momento de serem reapresentadas no futuro, mas porque o meio encontrado 
para dar voz a esses discursos é a própria mensagem. A sentença de Mc Luhan $^{63}$ foi apropriada de forma revolucionária pelos meios e contra os meios. O discurso direto, não mediatizado (representado em outras falas), onde cada manifestante falava em nome próprio, pode ser considerado o paroxismo do que muitos chamaram de "crise de representação", talvez por não compreenderem que a representação é a crise. $O$ conjunto dessas memórias é a expressão mais próxima que tivemos da efetivação da democracia direta, onde o subalterno (assim entendido no sentido de Spivak) pôde ser vocalizado (e ouvido) em sua própria voz.

A análise dos gráficos do capítulo anterior revelou a prática renitente de alienação do falante com o discurso atribuído a ele, isto é, a prática de criar "dobras" na comunicação.

\begin{abstract}
Desse modo, os "diz-se que" e os "diz-se que se diz" se acumulam, traçando círculo cada vez mais longínquos através de um mapa fantasioso. A voz de Heródoto é uma voz em "off", que fala por meio de uma multidão de outras vozes" (CAUQUELIN, 2007, p.50).

E, com efeito, a interpretação se faz sempre em nome de alguma coisa que se supõe estar faltando. A unidade é precisamente aquilo que falta à multiplicidade, assim como o sujeito é aquilo que falta ao acontecimento (DELEUZE, 1992, p.183).
\end{abstract}

Os apagamentos e distorções, tratados por Rossi, são a tentativa de sufocar essas vozes nas águas do esquecimento do lago mortal de Lethes. Por isso, para se efetivar o direito à memória é preciso estar atento ao presente, não somente, como observou Foucault, no que diz respeito ao conteúdo discursivo, mas principalmente no que ele chamou de "técnicas polimorfas de poder" que controlam o saber. A efetivação do direito à memória deve estar orientada para o presente porque as estruturas de violência física e simbólica permanecem, como concluiu o relatório da Comissão Nacional da Verdade. As memórias sobre as manifestações deram o testemunho da persistência das violações ocorridas no passado, não apenas exibindo os métodos truculentos da força policial utilizada contra os

\footnotetext{
${ }^{63}$ Referência à expressão amplamente conhecida “o meio é a mensagem", criada pelo sociólogo Marshall Mc Luhan.
} 
manifestantes, mas porque mostrou que a mídia tradicional exerce um “direito à censura" (SERRANO, 2013, p. 78) travestido de liberdade de expressão. O jornalismo que após 50 anos reconhecia o erro de no passado ter apoiado a ditadura, era aquele que trazia o passado de volta sob os mesmos moldes autocráticos ${ }^{64}$.

Explodir o "continuum da história", como pretendeu Benjamin (1994, p.230) não se faz eternamente com revisionismos e Comissões da Verdade. Tampouco esperando a contradição dialética transformar potência em ato no futuro. Explodir o continuum da história é fazer o tigre saltar sobre o presente, reorientando seu sentido messiânico. É nessa direção e sentido que o direito à memória deve ser aplicado, junho de 2013 assim o demonstrou.

\footnotetext{
${ }^{64}$ No dia 31 de agosto de 2013 o jornal O Globo lança um site onde conta sua história e disponibiliza digitalmente todo conteúdo jornalístico que produziu, desde sua fundação em 1925. $\mathrm{Na}$ ocasião publicou um texto onde reconhecia o erro do apoio editorial ao Golpe de 1964 . Na primeira frase reconhece: "Desde as manifestações $d$ ejunho, um coro voltou às ruas: 'A verdade é dura, a Globo apoiou a ditadura'. De fato, trata-se de uma verdade, e, também de fato, de uma verdade dura". Disponível em: http://oglobo.globo.com/brasil/apoio-editorial-ao-golpe-de-64-foi$\underline{\text { um-erro-9771604 }}$
} 


\section{CONCLUSÃO}

Nós praticamente só percebemos o passado, o presente puro sendo o avanço invisível do passado consumindo o futuro. (Henri Bergson ${ }^{65}$ )

O presente trabalho teve como objetivo debater as narrativas das manifestações de junho 2013 produzidas pelas novas e velhas mídias à luz do direito à memória. Inicialmente o conceito de memória foi apresentado enquanto construção social e coletiva, sob a perspectiva de teóricos referenciais para a compreensão do tema. As diversas abordagens revelaram elementos comuns: a intrínseca relação entre memória, esquecimento, tempo, espaço, ideologia, grupos de poder, produção do saber e dominação simbólica. Eles também aparecem na memória produzida pela mídia.

Num segundo momento, o direito à memória, embora não constitucionalmente positivado em nosso ordenamento jurídico, foi apresentado como um direito fundamental, tendo como base o entendimento doutrinário vigente. Em seguida foram apresentadas as principais perspectivas em que o direito à memória é aplicado em sua dimensão coletiva: como patrimônio cultural, como um direito a ser efetivado pela justiça de transição e finalmente, como um direito aplicado às produções dos meios de comunicação, abordagem esta que interessava mais diretamente ao objetivo proposto. Em todas essas abordagens ficou demonstrada uma profunda influência de um discurso ordenador dos grupos de poder na seleção de conteúdos de memória.

Essa mesma influência ficou ainda mais evidente nas análises de discursos midiáticos sobre as manifestações de junho de 2013, onde foram apresentados estudos com metodologias estatísticas que avaliaram as produções das mídias alternativas e mídias tradicionais, tanto sob o aspecto do conteúdo quanto da circulação de informações sobre as manifestações. Ficou patente um contraste entre novas e velhas mídias não apenas pela forma de distribuição da informação, como pelo modo de abordagem dos

\footnotetext{
${ }^{65}$ Matéria e Memória: ensaio sobre a relação do corpo com o espírito, São Paulo: Martins Fontes, 1990.
} 
acontecimentos e o sentido atribuído a eles. As redes de mídias alternativas se mostraram mais plurais e democráticas, tanto por vocalizar os invisibilizados, quanto por fazer circular conteúdos heterogêneos que alcançaram grande número de pessoas, enquanto os velhos grupos de comunicação procuraram traduzir e homogeneizar as reivindicações das multidões, seja alienando o falante de sua fala e dos debates travados nas ruas, seja categorizando os manifestantes entre legítimos (pacíficos) e ilegítimos (vândalos), ou ainda, desqualificando os veículos que abriram canal às vozes silenciadas.

A disputa pelo sentido das manifestações inscreve-se nas lutas pelo poder de controlar a condução dos acontecimentos e seus desdobramentos, de influenciar a memória coletiva orientada para o presente e para o futuro. A disputa pela construção da memória coletiva sobre as manifestações de junho de 2013 tem caráter político que faz parte da própria natureza do direito à memória. Este apenas se efetiva se antecedido pela realização de outros direitos, como o direito à informação, à verdade e liberdade de expressão. Como as violações à memória se constroem no presente e se projetam no futuro, o direito à memória deve ser direcionado para o presente. A concretização desse direito depende da organização da sociedade civil em forçar a abertura de espaços dialógicos democráticos com a administração pública de modo a debater sobre a importância da preservação do que é valorizado como representação social por determinados grupos sociais. É o poder de mobilização desses grupos e sua capacidade de interferência no cenário político das forças sociais em disputa que em última instância pode exigir a materialização da memória aqui debatida como patrimônio efetivamente preservado.

Para que as vozes das ruas sobrevivam não apenas como memória subterrânea oral, mas cheguem ao futuro como direitos de quarta geração, como exemplo de resistência, isegoria e lição de democracia direta, é preciso que em seu conjunto sejam consideradas hoje bens dignos de tutela do direito à memória. Isto é, que sejam preservadas não como textos 
interpretados, escritos por intelectuais ou mediados de alguma maneira por quaisquer outros representantes, mas sim ouvidas no futuro exatamente sob a forma que escolheram ser: gritos!

Desse modo, há de ser também uma democracia isenta já das contaminações da mídia manipuladora, já do hermetismo de exclusão, de índole autocrática e unitarista, familiar aos monopólios do poder. Tudo isso, obviamente, se a informação e o pluralismo vingarem por igual como direitos paralelos e coadjutores da democracia; esta porém, enquanto direito do gênero humano, projetado e concretizado no último grau de sua evolução conceitual (BONAVIDES, Paulo, 2011 p.571) 


\section{BIBLIOGRAFIA}

ABRÃO, Paulo; GENRO, Tarso. Justiça de Transição. In: AVRITZER, Leonardo [et al] (Orgs.). Dimensões Políticas da Justiça. Rio de Janeiro: Civilização Brasileira, 2013. p. 579-591

APPLEBAUM, Anne. What the Occupy protests tell us about the limits of democracy. Disponível em:

http://www.washingtonpost.com/opinions/what-the-occupy-protests-tell-usabout-the-limits-of-democracy/2011/10/17/gIQAay5YsL_story.html Acesso em 24 mai. 2015

AUGÉ, Marc. Não-Lugares. Introdução a uma antropologia da supermodernidade. $4^{\mathrm{a}}$ ed. Campinas: Papirus, 1994.

BARBOSA, Marialva. Os Donos do Rio: Imprensa, Poder e Público. Rio de Janeiro: Vício de Leitura, 2000. 257 p.

BENJAMIN, Walter. Sobre o conceito de história. In: BENJAMIN, Walter. Magia e Técnica, arte e Política. Obras Escolhidas. vol. 1. $7^{\mathrm{a} e d . ~ S a ̃ o ~ P a u l o: ~}$ Brasiliense, 1994. p. 222-232.

BONAVIDES, Paulo. Curso de Direito Constitucional. 26 ${ }^{\mathrm{a}}$ ed. São Paulo: Malheiros, 2011. 690 p.

BORBA, Maria; FELIZI, Natasha; REYS, João Paulo (Orgs.). Brasil em Movimento. Reflexões a partir dos protestos de junho. Rio de Janeiro: Rocco, 2014

BOSCO, Francisco. Acusados e acusadores. Disponível em: http://oglobo.globo.com/cultura/acusados-acusadores-9509047 Acesso em 24 mai. 2015

BOURDIEU, Pierre. Sobre a Televisão. Rio de Janeiro: Jorge Zahar Ed., 1997. .O Poder Simbólico. $7^{\mathrm{a} e d}$. Rio de Janeiro: Bertrand Brasil, 2004.

BRANDÃO, Junito. Mitologia Grega. Petrópolis: Vozes, 1986. 419 p.

CANDAU, Joel. Memória e Identidade. São Paulo: Contexto, 2014

CANOTILHO, José Joaquim Gomes. Direito Constitucional e Teoria da Constituição. $7^{\mathrm{a}}$ ed. Coimbra: Almedina, 2010. 1522 p. 
CARTOGRAFIA de Espaços Híbridos. Disponível em http://interagentes.net/?p=62 Acesso em 25 mai/2015

CASTELLS, Manuel. A Sociedade em Rede. São Paulo: Paz e Terra, 1999.

.Redes de indignação e esperança: movimentos sociais na era da internet. Rio de Janeiro: Zahar, 2013.

CASTRO, Sonia Rabello de. O Estado na preservação de bens culturais: o tombamento. Rio de Janeiro. Renovar, 1991. 161p.

CAUQUELIN, Anne. A invenção da paisagem. São Paulo: Martins, 2007.

CAVA, Bruno. A multidão foi ao deserto: as manifestações no Brasil em 2013 (junho - outubro). São Paulo: Annablume, 2013. P. 61-63

CHAGAS, Mário. O pai de macuníma e o patrimônio espitirual In: ABREU, Regina; CHAGAS, Mário (Orgs.). Memória e Patrimônio. Ensaios Contemporâneos. Rio de Janeiro: DP\&A, 2003. 320 p. p.95-108.

CHAUÍ, Marilena de Sousa. Cultura e democracia: o discurso competente e outras falas. $3^{\mathrm{a}}$ ed. São Paulo: Moderna. 1982. 220 p.

CHEGOU a Hora do Basta. Estadão. Opinião. Disponível em http://opiniao.estadao.com.br/noticias/geral,chegou-a-hora-do-basta-imp,1041814 Acesso em 26 mai. 2015

COHEN, Margaret. A literatura panorâmica e a invenção dos gêneros cotidianos. In: CHARNEY, Leo; SCHWARTZ, Vanessa R. (Orgs.). $O$ cinema e a invenção da vida moderna. São Paulo. Cosac \& Naify, 2004. p.259-288

COUTINHO, Laura Maria. O Estúdio de Televisão e a Educação da Memória. Brasília: Plano, 2003. 159 p.

CUNHA FILHO, Francisco Humberto. Direitos culturais como direitos fundamentais no ordenamento jurídico. Brasília: Brasília Jurídica, 2000.

DANTAS, Fabiana Santos. Direito Fundamental à Memória. Recife. 283 f. Tese (Doutorado) em Direito. Universidade Federal de Pernambuco, 2009.

$66-72$

.Direito Fundamental à Memória. Curitiba: Juruá, 2010. p.

DELEUZE, Gilles. Conversações. São Paulo: Ed. 34, 1992. 232 p. 
FAUSTO, Boris. História do Brasil. 6a ed.São Paulo.Edusp:FDE. 1998. p.660

FERRÉZ. Capão pecado. São Paulo: Labortexto Editorial, 2000

FOUCAULT, Michel. Microfísica do Poder. $5^{\mathrm{a}}$ ed. Rio de Janeiro: Graal, 1985.

.História da Sexualidade. vol. 1 A vontade de saber. $17^{\mathrm{a}}$ ed. São Paulo: Graal, 2006. 174 p.

GUIMARAENS, Francisco. Considerações sobre a tutela lenta, gradual e insegura do direito à informação sobre a repressão política da ditadura empresarial-militar. In: ASSY, Bethania et al (Coord.). Direitos Humanos: Justiça, Verdade e Memória. Lumen Juris. Rio de Janeiro. 2013.p.397-422.

GOHN, Maria da Glória. Manifestações de junho de 2013 no Brasil e praças dos indignados no mundo. Petrópolis: Vozes, 2014. 160 p.

HALBWACHS, Maurice. A Memória Coletiva. São Paulo: Vértice, Editora Revista dos Tribunais, $1990.189 \mathrm{p}$.

HALL, Stuart. A identidade cultural na pós-modernidade. $11^{\mathrm{a}}$ ed. Rio de Janeiro: DP\&A, 2006. 104 p.

HARDT, Michael; NEGRI, Antonio. Império. $3^{a}$ ed. Rio de Janeiro; São Pauo: Record, 2001.

Multidão. Guerra e democracia na era do Império. $3^{\mathrm{a}}$ ed. Rio de Janeiro: Record, 2014.

HARVEY, David. Condição Pós-Moderna. São Paulo: Loyola, 1992.

2005.

A produção capitalista do espaço. São Paulo: Annablume,

A liberdade da cidade. In: MARICATO, Ermínia [et al.]. Cidades Rebeldes: Passe livre e s manifestações que tomaram as ruas do Brasil. São Paulo: Boitempo: Carta Maior, 2013. 112 p. p.27-34

HUYSSEN, Andreas. Seduzidos pela Memória. Rio de Janeiro: Aeroplano, 2000. $116 \mathrm{p}$.

JABOR, Arnaldo. Disponível em:

https://www.youtube.com/watch?v=EN8bXvMgCks Acesso em 26 mai $/ 2015$ 
LE GOFF, Jacques. História e Memória. Campinas: Unicamp, 1994

LEMOS, Ronaldo. Precisamos Falar dos Algorítmos. Disponível em: http://www1.folha.uol.com.br/colunas/ronaldolemos/2015/05/1629738precisamos-falar-dos-algoritmos.shtml\#. Acesso em 19 mai. 2015.

LIMA, Luis Cláudio da Silva. Depoimento (20 de mai. 2015). Entrevistador: Ingrid Borges de Lemos. Rio de Janeiro. 1 arquivo .mp3 (40 $\min$ )

LIMA, Venício A. de. Mídia, rebeldia urbana e crise de representação. In: MARICATO, Ermínia [et al.]. Cidades Rebeldes: Passe livre e $s$ manifestações que tomaram as ruas do Brasil. São Paulo: Boitempo: Carta Maior, 2013. 112 p. p.89-94

LUCKERSON, Victor. How Facebook is goingo to battle with youtube. Disponível em: http://time.com/3634472/fb-vs-youtube-video/ Acesso em 19 de mai. 2015

MARIANI, Bethania Sampaio Corrêa. Os primórdios da Imprensa no Brasil (Ou: de como o discuro jornalístico constrói memória). In: ORLANDI, Eni Puccineli (Org.) Discurso Fundador. A formação do país e a construção da identidade nacional. $2^{\mathrm{a}}$ ed. Campinas: Pontes, 2001. 31-41

MARX, Karl; ENGELS, Friedrich. A Ideologia Alemã. São Paulo: Expressão Popular, 2009. 126 p.

. Manifesto Comunista. São Paulo: Boitempo, 1998.

MC LUHAN, Marshall. A Galáxia de Gutenberg. São Paulo. Editora Companhia Nacional, 1977.

MEZAROBBA, Glenda. De que se fala, quando se diz justiça de transição? In: ASSY, Bethania et. al (Coord.). Direitos Humanos: Justiça, Verdade e Memória. Lumen Juris. Rio de Janeiro. 2013. p.245-260

MORTOS e desaparecidos políticos / Comissão Nacional da Verdade. Brasília: CNV, 2014. 1996 p. - (Relatório da Comissão Nacional da Verdade; v. 3)

MOURA et. al. A Justiça de Transição no Brasil - Um Caminho ainda a percorrer. In: AMBOS, Kai; SOARES, Inês Virginia P. \& ZILLI, Marcos (Coord.). Anistia, Justiça e Impunidade. Reflexões sobre a Justiça de Transição no Brasil. Rio de Janeiro. Fórum, 2010. p.134-193.

NIETZSCHE, Friedrich. Considerações Extemporâneas. In: Os Pensadores. São Paulo: Nova Cultural, 1999, p. 267-300. 
NOGUEIRA, Marco Aurélio. As ruas e a democracia. Brasília: Fundação Astrogildo Pereira; Rio de Janeiro: Contraponto, 2013. 228 p.

NORA, Pierre. Entre Memória e História: a Problemática dos Lugares. In: Projeto História. São Paulo: PUC, n. 10, 1993, p. 7-28.

OLIVEN, Ruben George. Patrimônio intangível: considerações iniciais. In: ABREU, Regina; CHAGAS, Mário (Orgs.). Memória e Patrimônio. Ensaios Contemporâneos. Rio de Janeiro: DP\&A, 2003. 320 p. p.77-80.

ORTRIWANO, Gisela Swetlana. A Informação No Rádio. São Paulo: Sumus, 1985.

PATROCÍNIO, Paulo Roberto Tonani. Narrar a margem. In: PONTES JR, Geraldo Ramos [et al.] (Orgs.). Cultura, Memória e Poder. Diálogos Interdisciplinares. Rio de Janeiro: ed. UERJ, 2013. p. 185-200

PEREIRA, Victor Hugo Adler. A incômoda e persistente memória da escravidão. In: PONTES JR, Geraldo Ramos [et al.] (Orgs.). Cultura, Memória e Poder. Diálogos Interdisciplinares. Rio de Janeiro: ed. UERJ, 2013. p. $185-200$

PILATTI, Adriano. O ano das maravilhas e dos pesadelos. In: CAVA, Bruno; COCCO, Giuseppe. Amanhã vai ser maior: o levante da multidão no ano que não terminou. São Paulo: Annablume, 2014. P. 51-64

PINTO, Mônica Rizzo Soares. Preservação de publicações eletrônicas: a questão do depósito legal. Rio de Janeiro. 133 f. Dissertação (mestrado) Universidade Federal do Estado do Rio de Janeiro. Programa de PósGraduação em Memória Social, 2011.

POLLAK, Michael. Memória, Esquecimento e Silêncio. In: Estudos Históricos. Rio de Janeiro: Cpdoc/FGV, vol. 2, n. 3, 1989, p. 3-15.

Memória e Identidade Social. In: Estudos Históricos. Rio de Janeiro: Cpdoc/FGV, vol. 5, n.10, 1992, p. 200-212.

POMIAN, Krzysztof. Memória. In: GIL, Fernando (Coord.) Enciclopédia Einaudi. Sistemática. Porto: Imprensa Nacional-Casa da Moeda, vol. 42, 2000, p. 507-516.

RETOMAR a paulista. Opinião. Folha de São Paulo. Disponível em http://www1.folha.uol.com.br/opiniao/2013/06/1294185-editorial-retomara-paulista.shtml. Acesso em 26 mai. 2015 
REYS, João Paulo. Um panorama dos dias quentes de junho de 2013 e além. In: BORBA, Maria; FELIZI, Natasha; REYS, João Paulo (Orgs.). Brasil em Movimento. Reflexões a partir dos protestos de junho. Rio de Janeiro: Rocco, 2014 p. 33-49

ROSSI, Paolo. O passado, a memória, o esquecimento: seis ensaios da história das ideias. São Paulo: UNESP, 2010. 240 p.

SAMPAIO, José Adércio L; ALMEIDA, Alex Luciano Valadares. Verdade e história: por um direito fundamental à verdade. In: SOARES, Inês Virginia P. \& KISHI, Sandra Akemi S. Memória e Verdade. A Justiça de Transição no Estado Democrático Brasileiro. Fórum, 2009. p. 249-267.

SANTOS, Myrian Sepúlveda dos. Memória Coletiva e Teoria Social. São Paulo: Annablume, 2003.

- Memória Coletiva, Trauma e Cultura: um Debate. In: Revista USP. São Paulo. n. 98, p.51-68, jun/jul/ago, 2013.

; PEIXOTO, Paulo. Patrimônios mundiais: fragmentação e mercantilização da cultura. In: PONTES JR, Geraldo Ramos [et al.] (Orgs.). Cultura, Memória e Poder. Diálogos Interdisciplinares. Rio de Janeiro: ed. UERJ, 2013. p. 47-67

SARLET, Ingo Wolfgang. A Eficácia dos Direitos Fundamentais. $10^{\mathrm{a}}$ ed. Porto Alegre: Livraria do Advogado, 2010. 494 p.

SECCO, Lincoln. As jornadas de junho. In: MARICATO, Ermínia [et al.]. Cidades Rebeldes: Passe livre e s manifestações que tomaram as ruas do Brasil. São Paulo: Boitempo: Carta Maior, 2013. 112 p. p.71-78

SERRANO, Pascual. Democracia e liberdade de imprensa. In: MORAES, Dênis de; RAMONET, Ignacio; SERRANO, Pascual. Mídia, poder $e$ contrapoder. São Paulo: Boitempo; Rio de Janeiro: FAPERJ, 2013. P.71-82

SILVA, José Afonso. Curso de Direito Constitucional Positivo. $32^{\mathrm{a}}$ ed. São Paulo: Malheiros, 2009. 868 p.

Malheiros, 2004.

Direito Ambiental Constitucional. 5aed. São Paulo:

SOARES, Ricardo Maurício Freire; SANTOS, Claiz Maria Pereira Gunça dos. As funções do Direito à verdade e à memória. In Revista Brasileira de Direito Constitucional - RBDC n. 19 - jan./jun. 2012. 
SÔLHA, Hélio Lemos. 'Media' e as manifestações de junho: controle e disputa. Disponível em http://observatoriodaimprensa.com.br/jornal-dedebates/_ed769_mediae_as_manifestacoes_de_junho_controle_e_disputa Acesso em 24 mai. 2015

SOUTO, Sérgio Montero. Imprensa e memória da copa de 50: a glória e a tragédia de Barbosa. 108 f. Niterói. Dissertação (Mestrado) - Programa de Pós-Graduação em Comunicação, Universidade Federal Fluminense, 2002.

SOUZA, Savia Cordeiro. A Justiça de transição brasileira: Lei 6683/79 e a luta contra uma política de esquecimento. Dissertação (Mestrado). Rio de Janeiro. 162 f. Pontifícia Universidade Católica, 2012.

SPIVAK, C. Gayatri. Pode o subalterno falar? Belo Horizonte: Editora UFMG, 2014.

STF, ADPF n. 130 , Rel. Min. Carlos Britto, julgado em 30/04/2009

STF, ADPF n. 153-DF, Rel. Min. Eros Grau, julgado em 29/04/2010

STF, RE 153531-8/ SC, Rel. Min. Marco Aurélio, Segunda Turma, julgado em 03/06/1997.

STJ, REsp 147.949/MG, Rel. Min. Garcia Vieira, Primeira Turma, julgado em 19/02/1998, DJ 20/04/1998, p. 35

TRINDADE, Karlili. Depoimento (19 de mai. 2015). Entrevistador: Ingrid Borges de Lemos. Rio de Janeiro. 1 arquivo .mp3 (30 min)

VAINER, Carlos. Quando a cidade vai às ruas. In: MARICATO, Ermínia [et al.]. Cidades Rebeldes: Passe livre e s manifestações que tomaram as ruas do Brasil. São Paulo: Boitempo: Carta Maior, 2013. 112 p. p.35-40

VERNANT, Jean Pierre. Mito e Pensamento entre os Gregos. $2^{\mathrm{a}}$ ed. Rio de Janeiro: Paz e Terra, 1990. 504p.

VOZES Silenciadas: mídia e protestos: a cobertura das manifestações de junho de 2013 nos jornais O Estado de São Paulo, Folha de São Paulo e O Globo. São Paulo: Intervozes - Coletivo Brasil de Comunicação Social, 2014. Disponível para download em: http://intervozes.org.br/publicacoes/vozes-silenciadas-midia-e-protestos-asmanifestacoes-de-junho-de-2013-nos-jornais-o-estado-de-s-paulo-folha-des-paulo-e-o-globo-cobriram-as-manifestacoes-de-junho/

WEICHERT, Marlon Alberto. Crimes contra a humanidade perpetrados no Brasil. Lei de anistia e prescrição penal. Revista Brasileira de Ciências Criminais, $\mathrm{n}^{\circ}$. 74, 2008. 
ZIZEK, Slavoj. O violento silencio de um novo começo. In: HARVEY, David [et al.]. Ocсupy. São Paulo: Boitempo: Carta Maior, 2012. 89 p. 1525

Problemas no paraíso. In: MARICATO, Ermínia [et al.]. Cidades Rebeldes: Passe livre e s manifestações que tomaram as ruas do Brasil. São Paulo: Boitempo: Carta Maior, 2013. 112 p. p.101-108 